\title{
GEOMAR
}

Helmholtz-Zentrum für Ozeanforschung Kiel

\section{RV POSEIDON Fahrtbericht / Cruise Report POS536/Leg 1}

\author{
DIPLANOAGAP: Distribution of Plastics \\ in the North Atlantic Garbage Patch
}

Ponta Delgada (Portugal) - Malaga (Spain)

17.08. - 12.09.2019

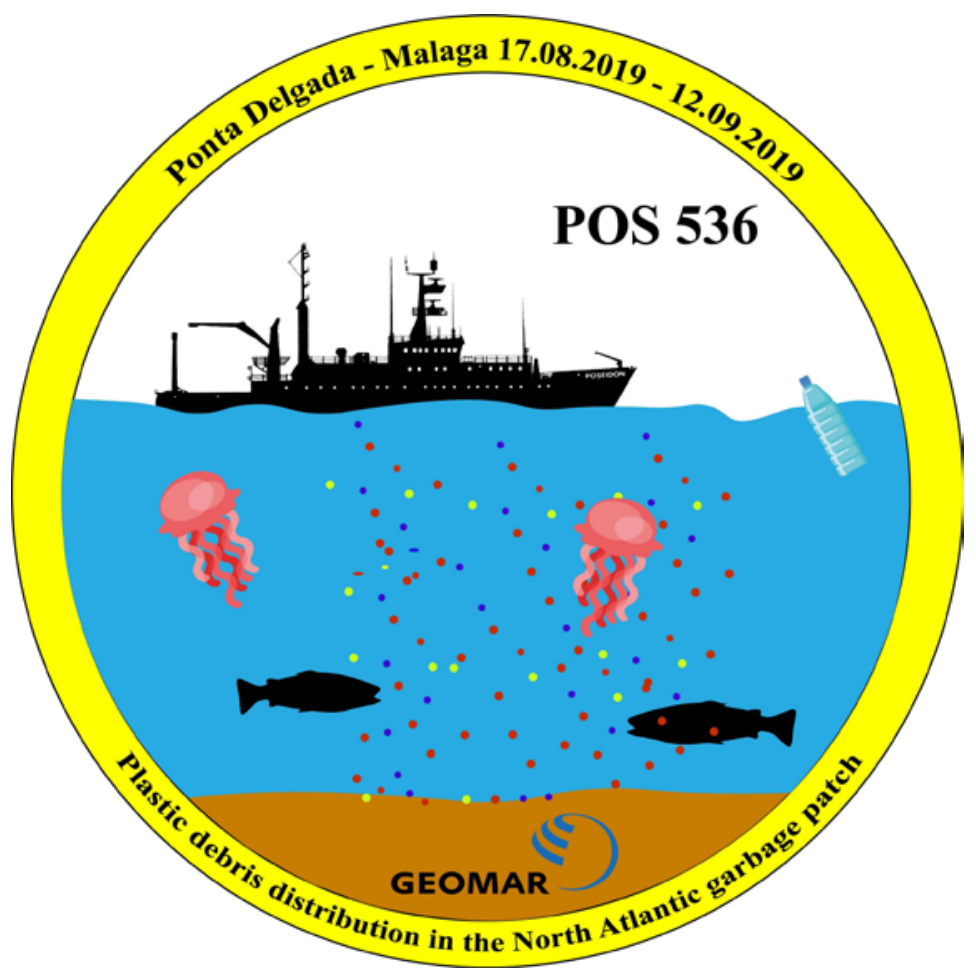

Berichte aus dem GEOMAR

Helmholtz-Zentrum für Ozeanforschung Kiel

Nr. 56 (N. Ser.)

October 2020 



\title{
GEOMAR
}

\section{Helmholtz-Zentrum für Ozeanforschung Kiel}

\section{RV POSEIDON Fahrtbericht / Cruise Report POS536/Leg 1}

\author{
DIPLANOAGAP: Distribution of Plastics \\ in the North Atlantic Garbage Patch
}

Ponta Delgada (Portugal) - Malaga (Spain)

17.08. - 12.09.2019

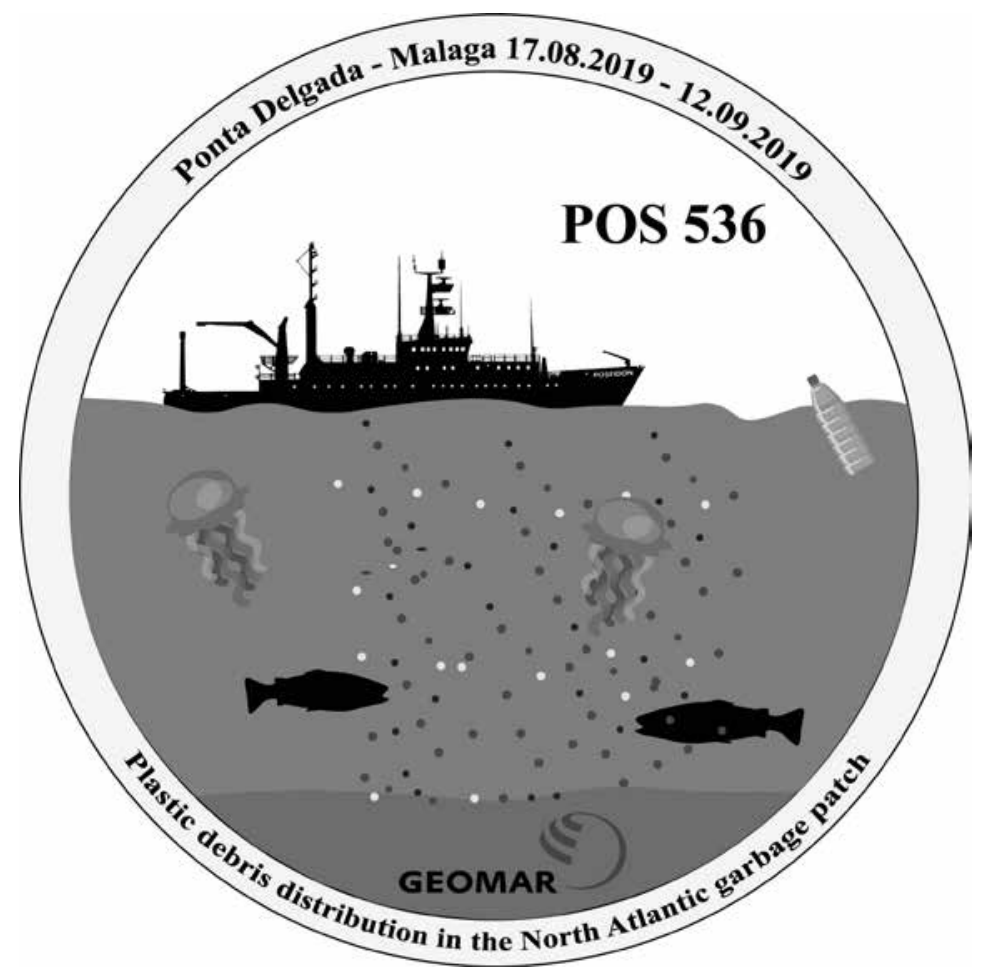

Berichte aus dem GEOMAR

Helmholtz-Zentrum für Ozeanforschung Kiel

Nr. 56 (N. Ser.)

October 2020 


\section{GEOMAR}

Helmholtz-Zentrum für Ozeanforschung Kiel

Das GEOMAR Helmholtz-Zentrum für Ozeanforschung Kiel ist Mitglied der Helmholtz-Gemeinschaft

Deutscher Forschungszentren e.V.
The GEOMAR Helmholtz Centre for Ocean Research Kiel is a member of the Helmholtz Association of German Research Centres

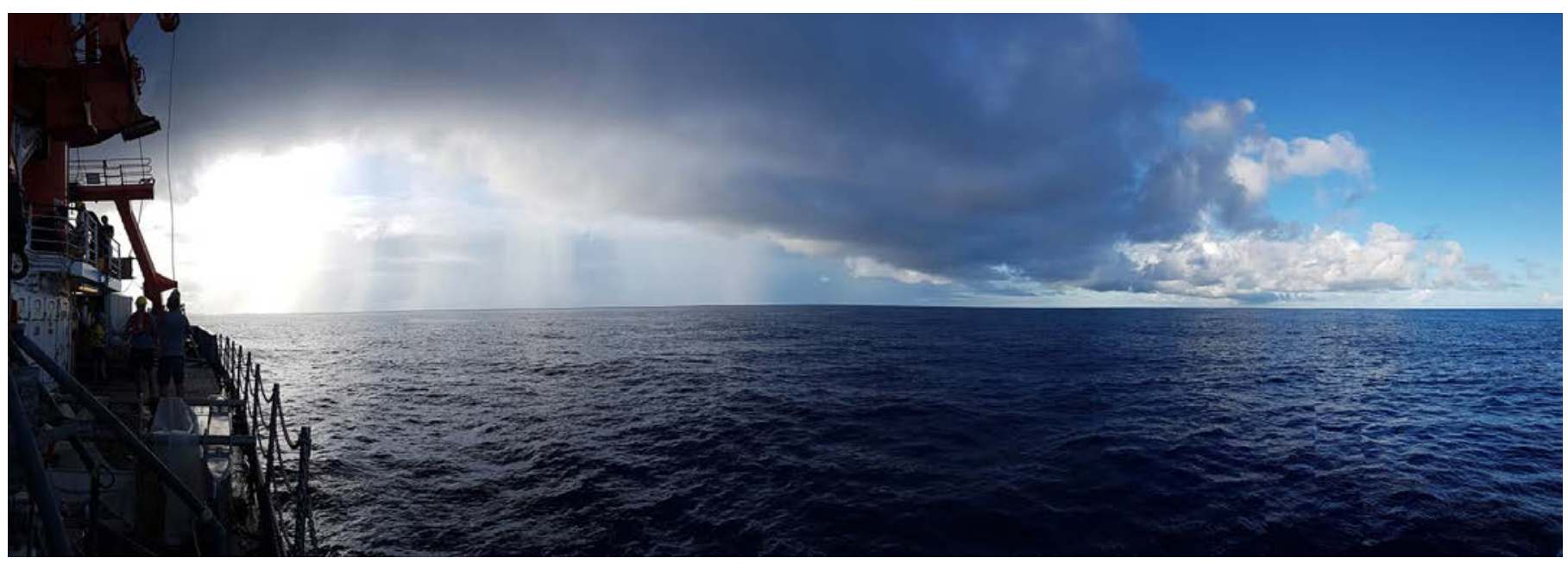

Autor / Author:

Mark Lenz

GEOMAR Report

ISSN Nr.. 2193-8113, DOI 10.3289/GEOMAR_REP_NS_56_2020

Helmholtz-Zentrum für Ozeanforschung Kiel / Helmholtz Centre for Ocean Research Kiel GEOMAR

Dienstgebäude Westufer / West Shore Building

Düsternbrooker Weg 20

D-24105 Kiel

Germany

Helmholtz-Zentrum für Ozeanforschung Kiel / Helmholtz Centre for Ocean Research Kiel GEOMAR

Dienstgebäude Ostufer / East Shore Building

Wischhofstr. 1-3

D-24148 Kiel

Germany

Tel.: +49 $431600-0$

Fax: +49 431 600-2805

www.geomar.de 


\section{Table of Contents}

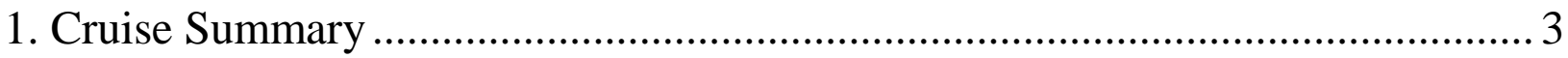

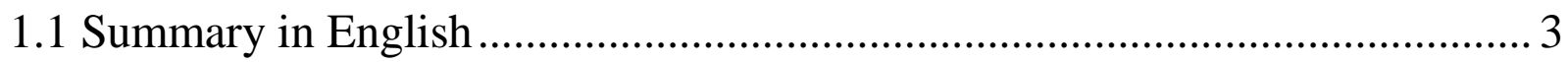

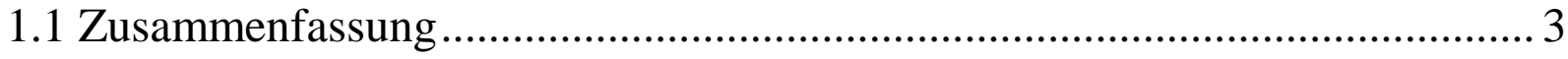

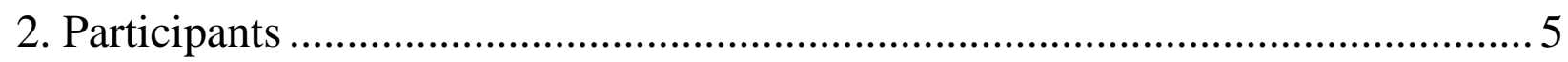

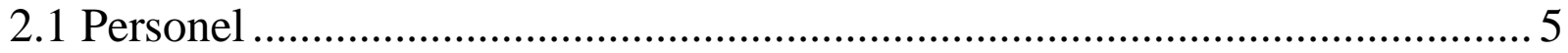

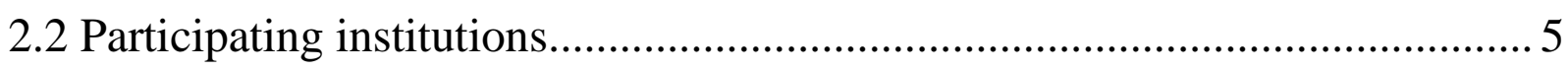

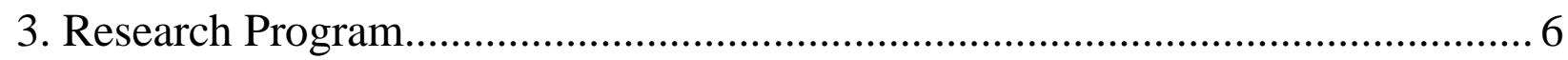

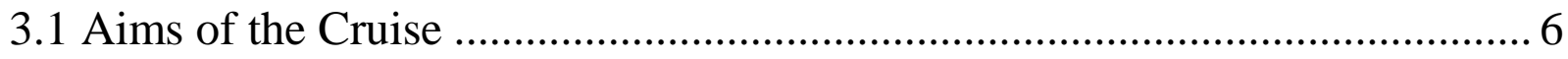

3.2 Description of the Work Area .................................................................. 7

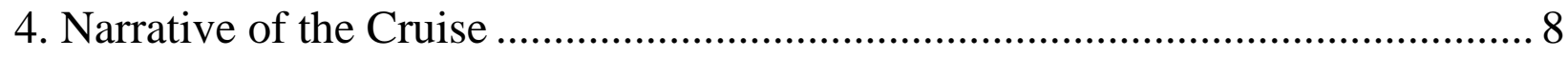

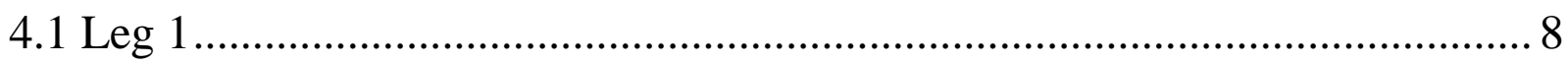

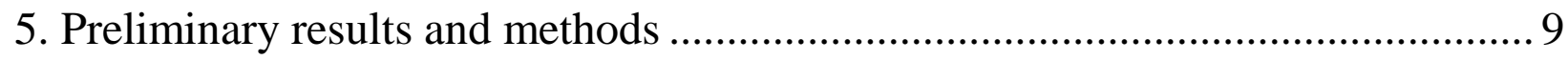

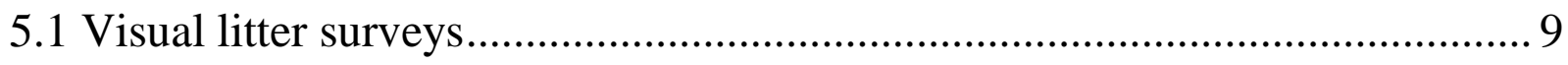

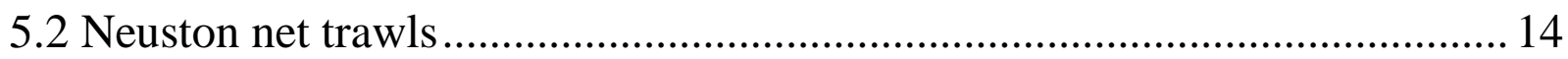

5.2.1. Analysis of microbial communities on macroplastics …............................ 16

5.3 Vertical sampling of the water column with the WP2 plankton net.............. 19

5.4 Horizontal water column sampling with the bongo net .................................22

5.5 Sediment sampling with multiple coring and box coring .............................28

5.6 Thorium isotope tracer measurements and particle filtration with the Kiel-In-

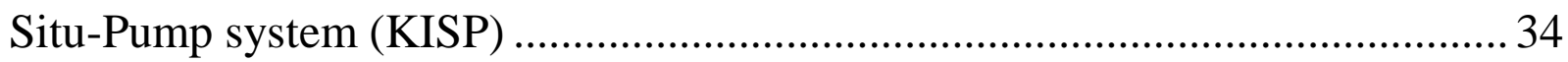

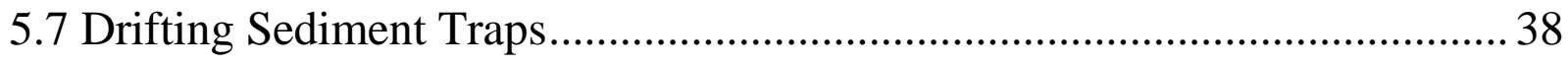

5.8 CTD and water sampler rosette............................................................... 43

$5.9 \mathrm{pCO} 2$ and microplastic sampling in the mixed layer................................... 45 


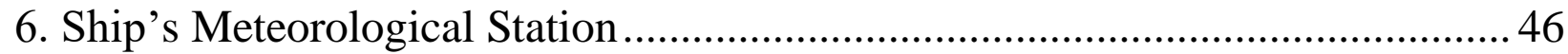

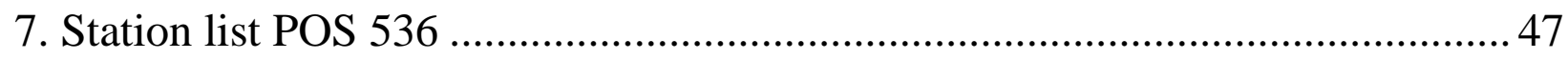

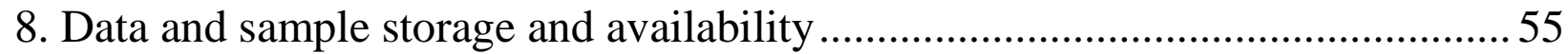

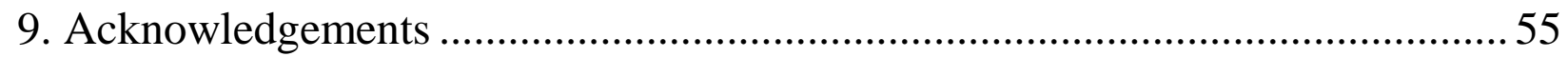

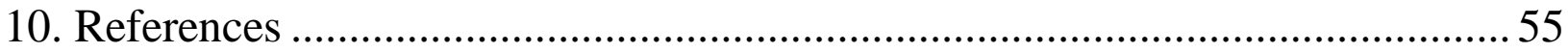




\section{Summary}

\subsection{Summary in English}

The expedition POS 536 is part of a multi-disciplinary research initiative of GEOMAR investigating the origin, transport and fate of plastic debris from estuaries to the oceanic garbage patches. The main focus will be on the vertical transfer of plastic debris from the surface and near-surface waters to the deep sea and on the processes that mediate this transport. The obtained data will help to develop quantitative models that provide information about the level of plastic pollution in the different compartments of the open ocean (surface, water column, seafloor).

Furthermore, the effects of plastic debris on marine organisms in the open ocean will be assessed. The cruise will provide data about the:

(1) abundance of plastic debris with a minimum size of $100 \mu \mathrm{m}$ as well as the composition of polymer types in the water column at different depths from the sea surface to the seafloor including the sediment,

(2) abundance and composition of plastic debris in organic aggregates ("marine snow"),

(3) in pelagic and benthic organisms (invertebrates and fish) and in fecal pellets,

(4) abundance and the identity of biofoulers (bacteria, protozoans and metazoans) on the surface of plastic debris from different water depths,

(5) identification of chemical compounds ("additives") in the plastic debris and in water samples.

\subsection{Zusammenfassung}

Eine multidisziplinäre Forschungsinitiative des GEOMAR soll in den kommenden Jahren die Herkunft, den Transport und den Verbleib von Plastikmüll von den Mündungen großer Flüsse bis zu den subtropischen Konvergenzzonen („Müllstrudel“) untersuchen. Im Besonderen soll der vertikale Transport des Plastiks quantifiziert und die involvierten Prozesse identifiziert werden.

Mit diesem Wissen sollen Modelle erstellt werden, die die Belastung des offenen Ozeans (Oberfläche, Wassersäule, Meeresboden) mit Plastikmüll abschätzen. Zudem sollen Erkenntnisse über die Auswirkungen der Plastikverschmutzung auf Organismen und Ökosysteme des offenen Ozeans gewonnen werden. Während der Expedition POS 535 wurden hierfür Proben gesammelt, die nach der Aufreinigung und Analyse mit Hilfe spektroskopischer Methoden bzw. der Gaschromatographie/Massenspektroskopie am GEOMAR Informationen liefern werden, die folgendes ermöglichen: 
Quantifizierung und Charakterisierung von Plastikpartikeln $(>100 \mu \mathrm{m})$ in verschiedenen Wassertiefen von der Meeresoberfläche bis zum Meeresboden. Hierfür wurden mit Hilfe eines Neuston-Netzes, eines WP2-Planktonnetzes, eines Bongo-Netzes sowie eines Kastengreifers Proben genommen. Zusätzlich wurden in-situ Pumpen eingesetzt, die in verschiedenen Wassertiefen definierte Volumina filtrierten.

Erfassung und Charakterisierung von Plastikpartikeln $(>100 \mu \mathrm{m})$ in Aggregaten [,,Marine Snow"] sowie in marinen Organismen und deren Fäzes. Hierfür wurden während der Fahrt an zwei Positionen driftende Sedimentfallen ausgebracht, die für jeweils 4 Tage in 8 verschiedenen Wassertiefen Aggregate sammelten

Identifizierung und Quantifizierung von Bakterien, Protozoen und Metazoen auf der Oberfläche von Plastikpartikeln.

Identifizierung von chemischen Zusatzstoffen (,Additive“) im gefundenen Plastikmüll und in Wasserproben. Hierfür und für Punkt 3 wurden händisch Plastikfragmente > $1000 \mu \mathrm{m}$ aus den Netzproben aussortiert. 


\section{Participant List}

\subsection{Scientific Party}

\begin{tabular}{|l|l|l|}
\hline Name & Discipline & Institution \\
\hline Dr. Mark Lenz & $\begin{array}{l}\text { Principle } \\
\text { Investigator, } \\
\text { Marine Ecology }\end{array}$ & GEOMAR \\
\hline Dr. Luisa Galgani & Biogeochemistry & $\begin{array}{l}\text { University } \\
\text { of Siena }\end{array}$ \\
\hline Dr. Erik Borchert & Marine Ecology & GEOMAR \\
\hline Thea Hamm & Marine Ecology & GEOMAR \\
\hline Jon Roa & $\begin{array}{l}\text { Biogeochemistry } \\
\text { Technician }\end{array}$ & GEOMAR \\
\hline André Mutzberg & $\begin{array}{l}\text { Biogeochemistry } \\
\text { Technician }\end{array}$ & GEOMAR \\
\hline $\begin{array}{l}\text { Ulrike Christiane } \\
\text { Panknin }\end{array}$ & $\begin{array}{l}\text { Marine Ecology } \\
\text { Technician }\end{array}$ & GEOMAR \\
\hline Kristin Hamann & $\begin{array}{l}\text { Biogeochemistry, } \\
\text { Co-Chief } \\
\text { Scientist }\end{array}$ & GEOMAR \\
\hline Jenny Friedrich & Student helper & CAU Kiel \\
\hline $\begin{array}{l}\text { Sarah-Marie } \\
\text { Kröger }\end{array}$ & Student helper & CAU Kiel \\
\hline $\begin{array}{l}\text { Lindsay Grace } \\
\text { Walls }\end{array}$ & Student helper & CAU Kiel \\
\hline
\end{tabular}

\subsection{Participating institutions}

GEOMAR Helmholtz-Zentrum für Ozeanforschung Kiel University of Siena 


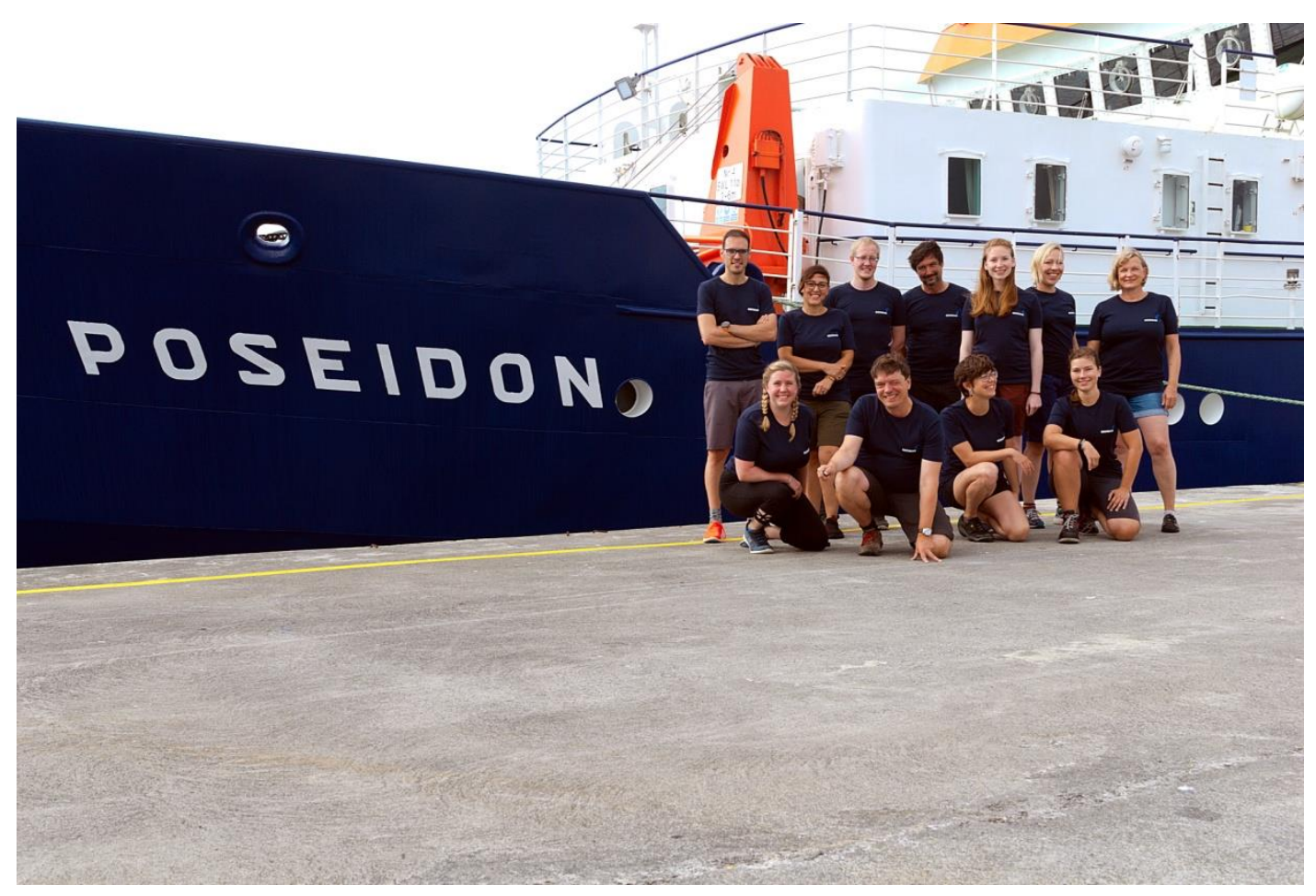

Scientific Party

\section{Research Program}

\subsection{Aims of the Cruise}

The POS536 research cruise serves as a starting point of a number of connected research cruises to build an understanding of the transport pathways of plastic and microplastic debris in the North Atlantic from the input through rivers and air across coastal seas into the accumulation spots in the North Atlantic gyre and the vertical export to its final sink at the seabed.

Assessing the abundance, composition and size distribution of micro- and mesoplastic particles $(0.3-200 \mathrm{~mm})$ at the sea surface in the working area using a neuston catamaran trawl

Assessing the abundance, composition, size distribution and transport rates of micro- and mesoplastic particles $(0.1-5 \mathrm{~mm})$ in the water column using drifting sediment traps

Assessing the abundance and size distribution of microplastic particles $(0.1-5 \mathrm{~mm})$ in the water column using in situ pumps

Assessing the abundance, composition and size distribution of microplastic particles $(0.2-$ $5 \mathrm{~mm}$ ) near the surface using subsurface underway samples

Assessing the abundance, composition and size distribution of micro- and mesoplastic particles $(0.1-200 \mathrm{~mm})$ as well as of phyto- and zooplankton organisms including jellyfish in the water column using a multi-net trawl

Measuring concentrations of selected additive compounds that commonly leach from plastic materials

Capturing fish of species feeding in the upper layer $(5-10 \mathrm{~m})$ and mid-layer $(50-200 \mathrm{~m})$ of the water column using an Isaacs-Kidd midwater trawl

Assessing the abundance, composition and size distribution of micro- and mesoplastic particles $(0.1-200 \mathrm{~mm})$ in seafloor sediments as well as in epi- and infauna organisms 
Describing the abundance and composition of bacterial biofilms and of eukaryotic biofoulers on micro- and mesoplastic particles from the sea surface, the water column and the seafloor

Assessing the role of eddies in the horizontal, long-distance transport of buoyant micro- and mesoplastics $(0.1-200 \mathrm{~mm})$

\subsection{Description of the Work Area}

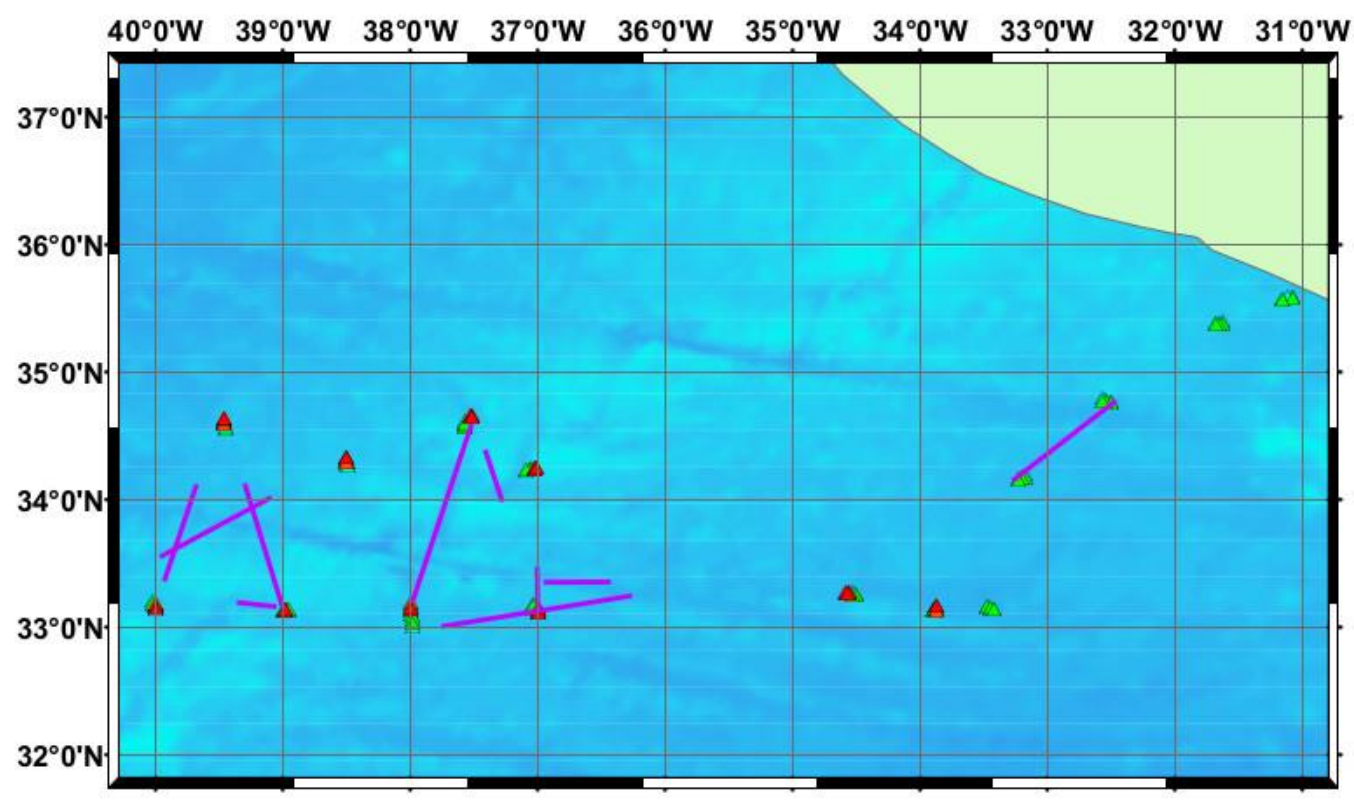

Figure 3.2 Map of POS536, location of the working area and stations (symbols: green=neuston trawls, red=bongo net trawls), litter monitoring transects (purple lines) and Portuguese EEZ (light green area). 


\section{Narrative of the Cruise}

\subsection{Leg 1}

The scientific crew with 11 researchers, technicians and student helpers embarked RV POSEIDON in Ponta Delgada/Azores on August $16^{\text {th }}$ 2019. The vessel left the harbour on the following day and headed south-west towards the working area at the north-eastern edge of the inner accumulation zone of the North Atlantic garbage patch.

This garbage patch, which spans from the Azores to Bermuda, is supposed to contain $20 \%$ of the global amount of floating plastic. At 11 stations along the north-eastern edge of the patch, we collected samples that will allow to assess the abundance of microplastics, i.e. synthetic particles in a size range between 20 and $5000 \mu \mathrm{m}$, at the ocean surface, in various water depths between $0 \mathrm{~m}$ and $1500 \mathrm{~m}$ and at the ocean floor $(3000 \mathrm{~m})$.

Samples encompassed sea water, marine organisms and sediment and we used various sampling techniques: surface (manta) trawls, subsurface bongo net trawls, vertical plankton hauls, in-situ water pumps, pelagic sediment traps, multicoring, box coring, the underway seawater system and the OceanPack ${ }^{\mathrm{TM}}$ Race. To characterize the oceanographic conditions at the stations where samples were taken, the CTD of RV POSEIDON was used.

During the first week of the cruise $\left(17^{\text {th }}-24^{\text {th }}\right.$ August 2019), we set-up the laboratories and prepared the different sampling devices for their first deployment. As soon as we had left the EEZ of Portugal, we started sampling with the Ocean Pack and also began with the visual litter monitoring (see below).

Furthermore, samples were taken at three stations, of which two were located in the working area, while the third one was inside an ocean eddy that we passed by on our way from the Azores to the working area.

The entire sampling gear despite the multicorer (MUC) worked well, while the latter was too light-weighted to penetrate into the very dense and hard deep-sea sediment that we encountered at the stations. This was the case at all stations in the working area, so that no sediment cores were collected with the MUC.

During a first visual inspection of the sampled material, we already detected significant quantities of plastic particles in the manta trawl samples. Furthermore, we were able to deploy the drifting sediment traps on the $22^{\text {nd }}$ of August 2019. Their position was constantly tracked via a satellite signal and we took them back on board on August $27^{\text {th }} 2019$.

The visual litter monitoring allowed to count and to categorize large-sized drifting litter objects during our transits from one station to the next. For this, a protocol, which was developed by colleagues from the Alfred-Wegener-Institute for Polar and Ocean Research, was adopted. It included the observation of the sea surface in a $10 \mathrm{~m}$ range on both sides of the vessel, what was done by two observers who were standing on the foredeck of the vessel.

During the second week $\left(25^{\text {th }}-31^{\text {st }}\right.$ August 2019), we finished sampling at the six stations in our rectangular working area between $33^{\circ} 09.00 \mathrm{~N} / 40^{\circ} 00.00^{\circ} \mathrm{W}$ and $33^{\circ} 15.00^{\prime} \mathrm{N} / 37^{\circ}$ $00.00^{\prime} \mathrm{W}$. Furthermore, we deployed the drifting sediment traps for the second time on August $29^{\text {th }} 2019$. Since we were two days ahead of our schedule, we added an extra sampling station at the position $34^{\circ} 14.74^{\prime} \mathrm{N} / 37^{\circ} 00.76^{\prime} \mathrm{W}$, which we reached in the morning of September $2^{\text {nd }}$ 2019. 
After the sampling at this station was accomplished, we went to retrieve the sediment traps, which we took on board again in the morning of September $3^{\text {rd }} 2019$.

Due to the fact that we still had 9 days available for the transit to Malaga, we decided to sample at a further extra station at $33^{\circ} 09.898^{\prime} \mathrm{N} / 033^{\circ} 52.552^{\prime} \mathrm{W}$. This was accomplished in the evening of September $4^{\text {th }} 2019$ and we then left the working area to start our transit to Malaga, Spain, which we reached in the evening of September $11^{\text {th }} 2019$. During the entire cruise, the weather conditions were excellent with low winds, short and moderate events of rain fall that were intercepted by long sunny periods. The water and air temperatures ranged between $25^{\circ} \mathrm{C}$ and $30^{\circ} \mathrm{C}$. This was problematic for the crew member who operated the winch, since the temperature in the glass cabin reached extreme values.

However, weather conditions changed during the transit back to Malaga, when wind speed increased and we had large waves hitting the port side of the vessel. They damaged the catamaran trawl, which was stowed on deck.

\section{Preliminary results and methods}

\subsection{Visual litter surveys}

(Mark Lenz and Shipboard Scientific Party)

\section{Research objectives and summary}

The majority of microplastic particles in the open ocean is supposed to have derived from the fragmentation of larger plastic debris (Andrady 2011).

Hence, it is plausible to assume that the abundance of microplastics is positively correlated with the abundance of macroplastic items. For this reason and to assess the general abundance of plastic litter in the working area and during transits from and to port, we conducted a visual litter monitoring. The data will later be correlated with the abundances of microplastics that we found in the water, sediment and biota samples, which collected in the respective sea area. Furthermore, the data will be provided for the Litterbase data repository that the AlfredWegener Institute for Marine and Polar Research (AWI) is maintaining.

\section{Method}

The method for this was adopted from a protocol, which was provided by the AWI.

Monitorings were subdivided into one hour shifts and were only conducted during transits, when the ship was moving with at least 4 knots.

For this, two members of the scientific crew stood on the foredeck of RV POSEIDON and counted all litter items down to a minimum size of approximately $5 \mathrm{~cm}$ that passed by the ship at a maximum distance of $10 \mathrm{~m}$. One person observed the sea on the starboard side, while the other person surveyed the portside of the ship. Litter items were documented with regard to their shape, size and colour as well was with regard to the material they consisted of. Each sighting was documented with its coordinates that were read from a handheld GPS device. 


\section{Preliminary results}

During 10 transits between stations within and also outside the working area, we observed the sea surface on both sides of the vessel (Figure 5.1-1a).

This is equivalent to a total survey time of 50 hours.

The monitorings revealed that the majority of litter items at the north-eastern edge of the North-Atlantic garbage patch were small fragments with a size smaller than $10 \mathrm{~cm}$ (Figure 5.12).

Only about $1 \%$ of all observed items were larger than $90 \mathrm{~cm}$, while $\sim 3 \%$ were larger than $50 \mathrm{~cm}$ (Figure 5.1-1b).

Figure 5.1-4 shows the size distribution of the litter items smaller than $50 \mathrm{~cm}$.

Furthermore, $99 \%$ of all the items that were counted and described during the cruise were classified as plastic.

The mean number of litter items that were observed during one of the 10 transects, during which the visual litter monitoring was conducted (Figure 5.1-3), ranged between 2 on transect 5 and 35 on transect 8 (Figure 5.1-5).

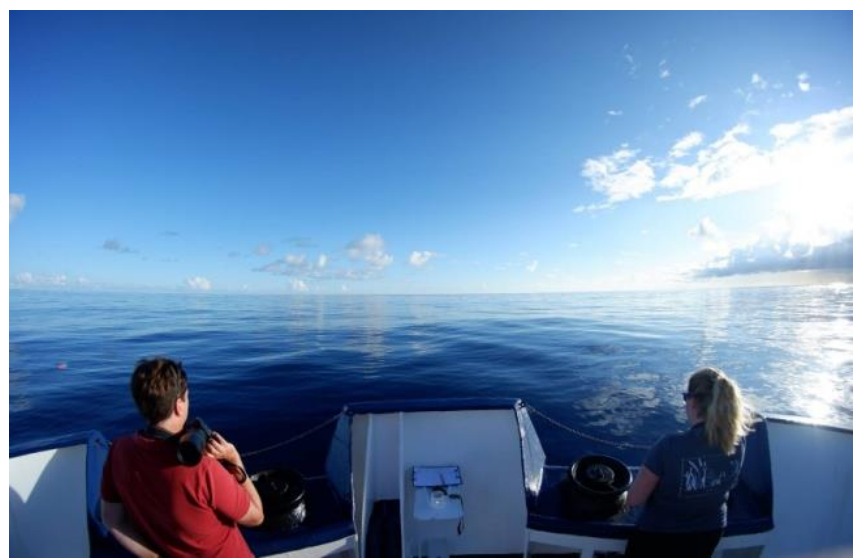

Figure 5.1-1a The litter monitoring was conducted by two researchers who stood on the foredock of RV Poseidon and surveyed an area of $10 \mathrm{~m}$ on the starboard and the port side of the vessel. Photo: Jon Roa.

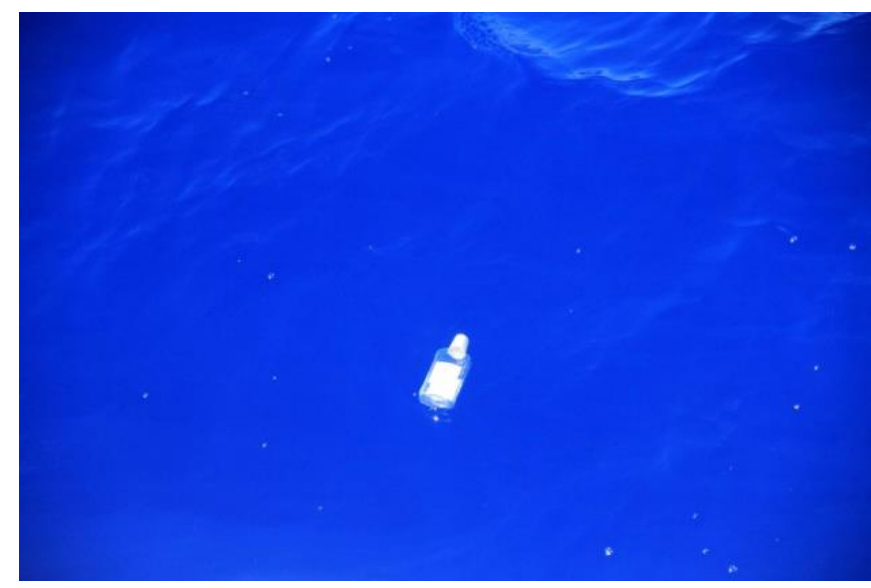

Figure 5.1-1 b Larger litter items like this plastic bottle were observed approximately once an hour, since the majority of debris items were small-sized fragments. Photo: Thea Hamm. 


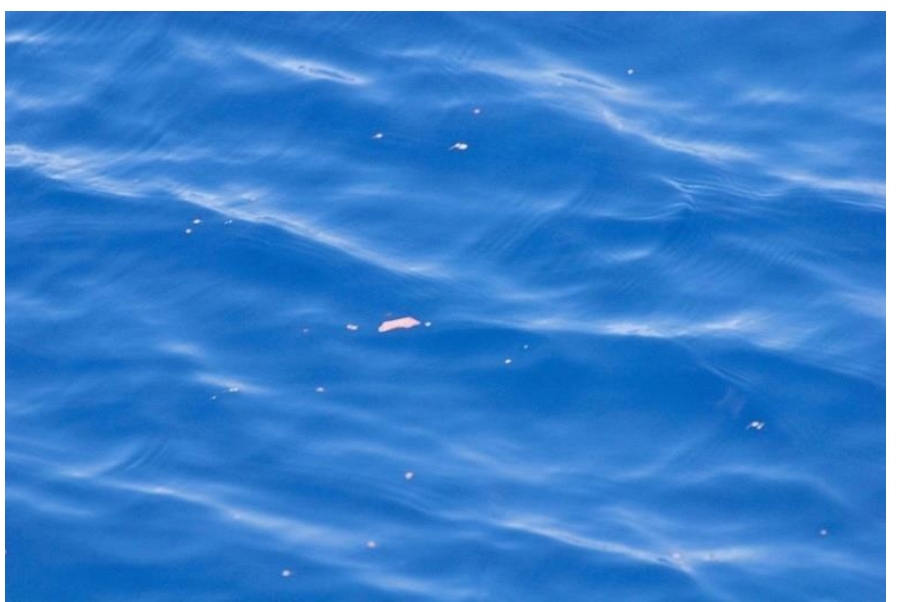

Figure 5.1-2 The majority of litter items that were observed during the monitorings were small-sized plastic fragments like the piece shown here, which was approximately $5 \mathrm{~cm}$ in length. Photo: Mark Lenz.

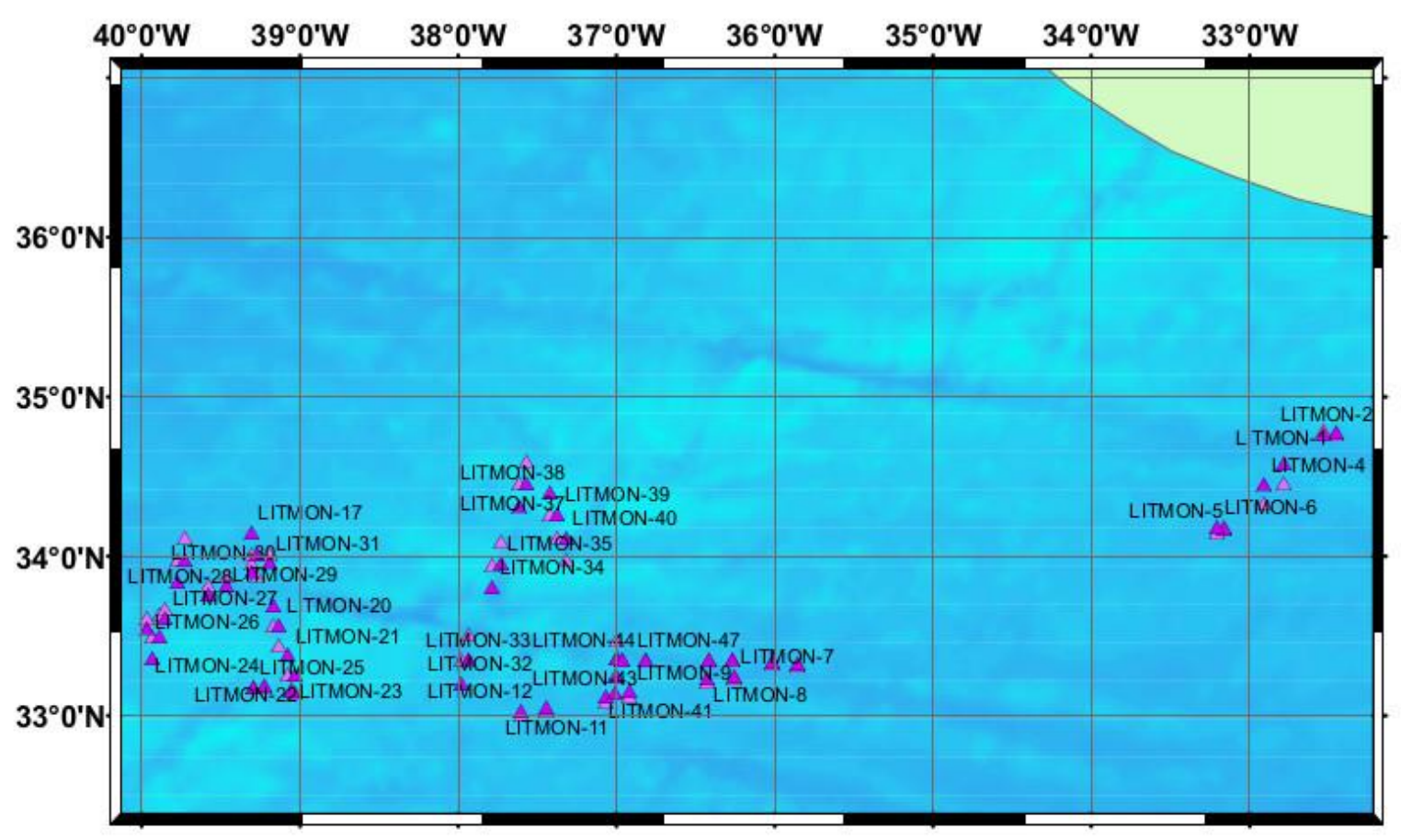

Figure 5.1-3 Visual litter monitorings conducted during POS536. 


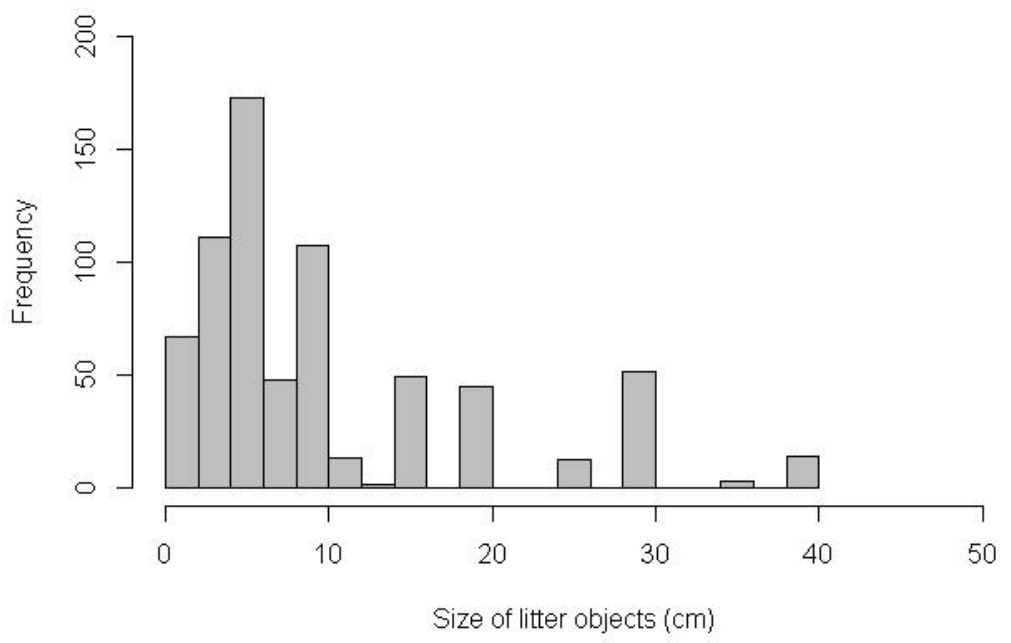

Figure 5.1-4 Size distribution of all litter items $<50 \mathrm{~cm}$ that were observed during the visual litter monitorings on the POS536 cruise.

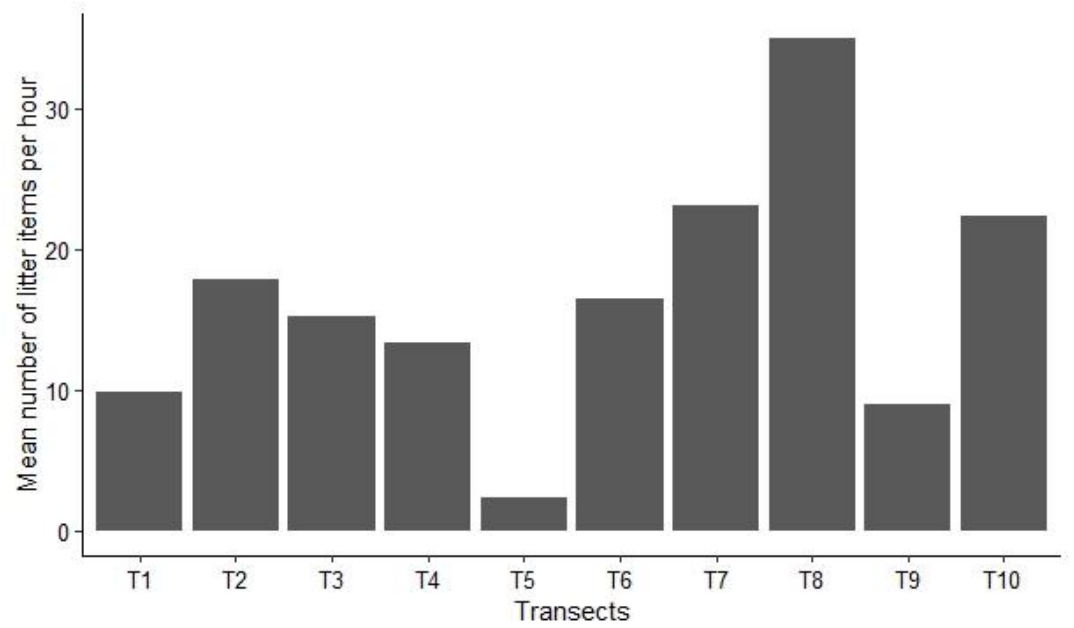

Figure 5.1-5 Mean number of litter items that were observed per hour on the different transects during which visual litter monitorings were conducted on the POS536 cruise (see Figure 5.1-3).

Table 5.1 Visual litter surveys during POS536.

\begin{tabular}{|l|l|l|l|l|l|l|l|}
\hline D-Ship & Date & $\begin{array}{l}\text { Time } \\
\text { (UTC) }\end{array}$ & Area & $\begin{array}{l}\text { Latitude } \\
\text { (start) }\end{array}$ & $\begin{array}{l}\text { Longitude } \\
\text { (start) }\end{array}$ & $\begin{array}{l}\text { Latitude } \\
\text { (end) }\end{array}$ & $\begin{array}{l}\text { Longitude } \\
\text { (end) }\end{array}$ \\
\hline POS536_0_Underway-1 & 19.08 .2019 & $08: 00$ & A-B & $34^{\circ} 46.7566^{\prime} \mathrm{N}$ & $32^{\circ} 27.550^{\prime} \mathrm{W}$ & $34^{\circ} 46.011^{\prime} \mathrm{N}$ & $32^{\circ} 31.689^{\prime} \mathrm{W}$ \\
\hline POS536_0_Underway-2 & 19.08 .2019 & $09: 00$ & A-B & $34^{\circ} 45.907^{\prime} \mathrm{N}$ & $32^{\circ} 32.061^{\prime} \mathrm{W}$ & $34^{\circ} 47.778^{\prime} \mathrm{N}$ & $032^{\circ} 34.965^{\prime} \mathrm{W}$ \\
\hline POS536_0_Underway-2 & 19.08 .2019 & $12: 00$ & A-B & $34^{\circ} 34.880^{\prime} \mathrm{N}$ & $32^{\circ} 47.328^{\prime} \mathrm{W}$ & $34^{\circ} 27.530^{\prime} \mathrm{N}$ & $32^{\circ} 54.034^{\prime} \mathrm{W}$ \\
\hline POS536_0_Underway-2 & 19.08 .2019 & $13: 00$ & A-B & $34^{\circ} 27.197^{\prime} \mathrm{N}$ & $32^{\circ} 54.342^{\prime} \mathrm{W}$ & $34^{\circ} 19.852^{\prime} \mathrm{N}$ & $33^{\circ} 01.039^{\prime} \mathrm{W}$ \\
\hline POS536_0_Underway-2 & 19.08 .2019 & $15: 30$ & A-B & $34^{\circ} 10.122^{\prime} \mathrm{N}$ & $33^{\circ} 09.997^{\prime} \mathrm{W}$ & $34^{\circ} 11.152^{\prime} \mathrm{N}$ & $33^{\circ} 12.553^{\prime} \mathrm{W}$ \\
\hline
\end{tabular}




\begin{tabular}{|c|c|c|c|c|c|c|c|}
\hline D-Ship & Date & $\begin{array}{l}\text { Time } \\
\text { (UTC) }\end{array}$ & Area & $\begin{array}{l}\begin{array}{l}\text { Latitude } \\
\text { (start) }\end{array} \\
\end{array}$ & $\begin{array}{l}\text { Longitude } \\
\text { (start) }\end{array}$ & $\begin{array}{l}\text { Latitude } \\
\text { (end) }\end{array}$ & $\begin{array}{l}\text { Longitude } \\
\text { (end) }\end{array}$ \\
\hline POS536_0_Underway-2 & 19.08.2019 & $16: 30$ & A-B & $34^{\circ} 11.185^{\prime} \mathrm{N}$ & $33^{\circ} 12.594^{\prime} \mathrm{W}$ & $34^{\circ} 08.890^{\prime} \mathrm{N}$ & $33^{\circ} 16.517^{\prime} \mathrm{W}$ \\
\hline POS536_0_Underway-2 & 21.08 .2019 & 08:00 & $\mathrm{B}-\mathrm{C}$ & $33^{\circ} 14.873^{\prime} \mathrm{N}$ & $36^{\circ} 15.452^{\prime} \mathrm{W}$ & $33^{\circ} 14.363^{\prime} \mathrm{N}$ & $36^{\circ} 25.606^{\prime} \mathrm{W}$ \\
\hline POS536_0_Underway-2 & 21.08.2019 & 09:00 & $\mathrm{B}-\mathrm{C}$ & $33^{\circ} 14.334^{\prime} \mathrm{N}$ & $36^{\circ} 25.789^{\prime} \mathrm{W}$ & $33^{\circ} 12.616^{\prime} \mathrm{N}$ & $36^{\circ} 35.660^{\prime} \mathrm{W}$ \\
\hline POS536_0_Underway-2 & 21.08 .2019 & $12: 00$ & $\mathrm{~B}-\mathrm{C}$ & $33^{\circ} 09.179^{\prime} \mathrm{N}$ & $36^{\circ} 54.823^{\prime} \mathrm{W}$ & $33^{\circ} 07.224^{\prime} \mathrm{N}$ & $37^{\circ} 04.077^{\prime} \mathrm{W}$ \\
\hline POS536_0_Underway-2 & 21.08 .2019 & $13: 00$ & B-C & $33^{\circ} 07.207^{\prime} \mathrm{N}$ & $37^{\circ} 04.150^{\prime} \mathrm{W}$ & $33^{\circ} 05.475^{\prime} \mathrm{N}$ & $37^{\circ} 13.077^{\prime} \mathrm{W}$ \\
\hline POS536_0_Underway-2 & 21.08 .2019 & $15: 30$ & B-C & $33^{\circ} 03.390^{\prime} \mathrm{N}$ & $37^{\circ} 26.891^{\prime} \mathrm{W}$ & $33^{\circ} 01.888^{\prime} \mathrm{N}$ & $37^{\circ} 36.010^{\prime} \mathrm{W}$ \\
\hline POS536_0_Underway-2 & 21.08 .2019 & $16: 30$ & $\mathrm{~B}-\mathrm{C}$ & $33^{\circ} 01.875^{\prime} \mathrm{N}$ & $037^{\circ} 36.073^{\prime} \mathrm{W}$ & $33^{\circ} 00.355^{\prime} \mathrm{N}$ & $37^{\circ} 45.414^{\prime} \mathrm{W}$ \\
\hline POS536_0_Underway-2 & 23.08 .2019 & $15: 30$ & C-D & $33^{\circ} 21.697^{\prime} \mathrm{N}$ & $39^{\circ} 55.798^{\prime} \mathrm{W}$ & $33^{\circ} 29.728^{\prime} \mathrm{N}$ & $39^{\circ} 53.137^{\prime} \mathrm{W}$ \\
\hline POS536_0_Underway-2 & 23.08 .2019 & $16: 30$ & C-D & $33^{\circ} 29.789^{\prime} \mathrm{N}$ & $39^{\circ} 53.117^{\prime} \mathrm{W}$ & $33^{\circ} 38.011^{\prime} \mathrm{N}$ & $39^{\circ} 50.383^{\prime} \mathrm{W}$ \\
\hline POS536_0_Underway-2 & 23.08 .2019 & 19:00 & C-D & $33^{\circ} 50.309^{\prime} \mathrm{N}$ & $39^{\circ} 46.291^{\prime} \mathrm{W}$ & $33^{\circ} 58.760^{\prime} \mathrm{N}$ & $39^{\circ} 43.485^{\prime} \mathrm{W}$ \\
\hline POS536_0_Underway-2 & 23.08.2019 & 20:00 & C-D & $33^{\circ} 58.822^{\prime} \mathrm{N}$ & $39^{\circ} 43.464^{\prime} \mathrm{W}$ & $34^{\circ} 07.267^{\prime} \mathrm{N}$ & $39^{\circ} 40.630^{\prime} \mathrm{W}$ \\
\hline POS536_0_Underway-2 & 25.08 .2019 & 12:00 & $\mathrm{D}$ & $34^{\circ} 08.943^{\prime} \mathrm{N}$ & $39^{\circ} 18.538^{\prime} \mathrm{W}$ & $34^{\circ} 01.025^{\prime} \mathrm{N}$ & $39^{\circ} 16.070^{\prime} \mathrm{W}$ \\
\hline POS536_0_Underway-2 & 25.08 .2019 & $13: 00$ & $\mathrm{D}$ & $34^{\circ} 00.958^{\prime} \mathrm{N}$ & $39^{\circ} 16.050^{\prime} \mathrm{W}$ & $33^{\circ} 52.973^{\prime} \mathrm{N}$ & $39^{\circ} 13.573^{\prime} \mathrm{W}$ \\
\hline POS536_0_Underway-2 & 25.08.2019 & $15: 30$ & $\mathrm{D}$ & $33^{\circ} 41.690^{\prime} \mathrm{N}$ & $39^{\circ} 10.079^{\prime} \mathrm{W}$ & $33^{\circ} 34.254^{\prime} \mathrm{N}$ & $39^{\circ} 07.775^{\prime} \mathrm{W}$ \\
\hline POS536_0_Underway-2 & 25.08 .2019 & $16: 30$ & $\mathrm{D}$ & $33^{\circ} 34.188^{\prime} \mathrm{N}$ & $39^{\circ} 07.756^{\prime} \mathrm{W}$ & $33^{\circ} 26.583^{\prime} \mathrm{N}$ & $39^{\circ} 05.409^{\prime} \mathrm{W}$ \\
\hline POS536_0_Underway-2 & 25.08 .2019 & 18:00 & D-E & $33^{\circ} 22.865^{\prime} \mathrm{N}$ & $39^{\circ} 04.269^{\prime} \mathrm{W}$ & $33^{\circ} 15.461^{\prime} \mathrm{N}$ & $39^{\circ} 01.987^{\prime} \mathrm{W}$ \\
\hline POS536_0_Underway-2 & 25.08 .2019 & 19:00 & D-E & $33^{\circ} 15.405^{\prime} \mathrm{N}$ & $39^{\circ} 01.968^{\prime} \mathrm{W}$ & $33^{\circ} 08.956^{\prime} \mathrm{N}$ & $38^{\circ} 59.988^{\prime} \mathrm{W}$ \\
\hline POS536_0_Underway-2 & 26.08 .2019 & $15: 30$ & E-F & $3309.649^{\prime} \mathrm{N}$ & $39^{\circ} 03.292^{\prime} \mathrm{W}$ & $33^{\circ} 10.295^{\prime} \mathrm{N}$ & $39^{\circ} 07.352^{\prime} \mathrm{W}$ \\
\hline POS536_0_Underway-2 & 26.08 .2019 & 18:00 & E-F & $33^{\circ} 11.033^{\prime} \mathrm{N}$ & $39^{\circ} 13.381^{\prime} \mathrm{W}$ & $33^{\circ} 10.597^{\prime} \mathrm{N}$ & $39^{\circ} 17.845^{\prime} \mathrm{W}$ \\
\hline POS536_0_Underway-2 & 26.08 .2019 & 19:00 & E-F & $33^{\circ} 10.593^{\prime} \mathrm{N}$ & $39^{\circ} 17.845^{\prime} \mathrm{W}$ & $33^{\circ} 11.609^{\prime} \mathrm{N}$ & $39^{\circ} 21.560^{\prime} \mathrm{W}$ \\
\hline POS536_0_Underway-2 & 27.08 .2019 & 12:00 & E-F & $33^{\circ} 33.097^{\prime} \mathrm{N}$ & $39^{\circ} 57.759^{\prime} \mathrm{W}$ & $33^{\circ} 36.625^{\prime} \mathrm{N}$ & $39^{\circ} 51.179^{\prime} \mathrm{W}$ \\
\hline POS536_0_Underway-2 & 27.08 .2019 & $13: 00$ & E-F & $33^{\circ} 36.655^{\prime} \mathrm{N}$ & $39^{\circ} 51.123^{\prime} \mathrm{W}$ & $33^{\circ} 40.156^{\prime} \mathrm{N}$ & $39^{\circ} 44.617^{\prime} \mathrm{W}$ \\
\hline POS536_0_Underway-2 & 27.08 .2019 & $15: 30$ & E-F & $33^{\circ} 45.482^{\prime} \mathrm{N}$ & $39^{\circ} 34.751^{\prime} \mathrm{W}$ & $33^{\circ} 48.963^{\prime} \mathrm{N}$ & $39^{\circ} 28.161^{\prime} \mathrm{W}$ \\
\hline POS536_0_Underway-2 & 27.08 .2019 & $16: 30$ & E-F & $33^{\circ} 49.005^{\prime} \mathrm{N}$ & $39^{\circ} 28.085^{\prime} \mathrm{W}$ & $33^{\circ} 52.529^{\prime} \mathrm{N}$ & $39^{\circ} 21.509^{\prime} \mathrm{W}$ \\
\hline POS536_0_Underway-2 & 27.08 .2019 & 18:00 & E-F & $33^{\circ} 54.313^{\prime} \mathrm{N}$ & $39^{\circ} 18.156^{\prime} \mathrm{W}$ & $33^{\circ} 57.698^{\prime} \mathrm{N}$ & $39^{\circ} 11.815^{\prime} \mathrm{W}$ \\
\hline POS536_0_Underway-2 & 27.08 .2019 & 19:00 & E-F & $33^{\circ} 57.727^{\prime} \mathrm{N}$ & $39^{\circ} 11.761^{\prime} \mathrm{W}$ & $34^{\circ} 01.146^{\prime} \mathrm{N}$ & $39^{\circ} 05.386^{\prime} \mathrm{W}$ \\
\hline POS536_0_Underway-2 & 30.08 .2019 & 08:00 & G-H & $33^{\circ} 12.420^{\prime} \mathrm{N}$ & $37^{\circ} 58.856^{\prime} \mathrm{W}$ & $33^{\circ} 21.374^{\prime} \mathrm{N}$ & $37^{\circ} 55.905^{\prime} \mathrm{W}$ \\
\hline $\begin{array}{l}\text { POS536_0_Underway-2 } \\
\end{array}$ & 30.08 .2019 & 09:00 & G-H & $33^{\circ} 21.448^{\prime} \mathrm{N}$ & $037^{\circ} 55.880^{\prime} \mathrm{W}$ & $33^{\circ} 30.440^{\prime} \mathrm{N}$ & $37^{\circ} 52.905^{\prime} \mathrm{W}$ \\
\hline POS536_0_Underway-2 & 30.08 .2019 & $12: 00$ & G-H & $33^{\circ} 48.565^{\prime} \mathrm{N}$ & $37^{\circ} 46.877^{\prime} \mathrm{W}$ & $33^{\circ} 57.078^{\prime} \mathrm{N}$ & $37^{\circ} 44.039^{\prime} \mathrm{W}$ \\
\hline POS536_0_Underway-2 & 30.08 .2019 & $13: 00$ & G-H & $33^{\circ} 57.155^{\prime} \mathrm{N}$ & $037^{\circ} 44.013^{\prime} \mathrm{W}$ & $34^{\circ} 05.617^{\prime} \mathrm{N}$ & $037^{\circ} 41.184^{\prime} \mathrm{W}$ \\
\hline POS536_0_Underway-2 & 30.08 .2019 & $15: 30$ & G-H & $34^{\circ} 18.948^{\prime} \mathrm{N}$ & $37^{\circ} 36.730^{\prime} \mathrm{W}$ & $34^{\circ} 27.345^{\prime} \mathrm{N}$ & $037^{\circ} 33.920^{\prime} \mathrm{W}$ \\
\hline POS536_0_Underway-2 & 30.08 .2019 & $16: 30$ & G-H & $34^{\circ} 27.368^{\prime} \mathrm{N}$ & $37^{\circ} 33.911^{\prime} \mathrm{W}$ & $34^{\circ} 35.719^{\prime} \mathrm{N}$ & $37^{\circ} 31.111^{\prime} \mathrm{W}$ \\
\hline POS536_0_Underway-2 & 31.08 .2019 & 18:00 & H-I & $34^{\circ} 24.194^{\prime} \mathrm{N}$ & $37^{\circ} 25.025^{\prime} \mathrm{W}$ & $34^{\circ} 15.770^{\prime} \mathrm{N}$ & $37^{\circ} 22.207^{\prime} \mathrm{W}$ \\
\hline POS536_0_Underway-2 & 31.08 .2019 & 19:00 & H-I & $34^{\circ} 15.707^{\prime} \mathrm{N}$ & $37^{\circ} 22.187^{\prime} \mathrm{W}$ & $34^{\circ} 07.284^{\prime} \mathrm{N}$ & $37^{\circ} 19.370^{\prime} \mathrm{W}$ \\
\hline POS536_0_Underway-2 & 31.08 .2019 & $20: 00$ & H-I & $34^{\circ} 07.196^{\prime} \mathrm{N}$ & $37^{\circ} 19.341^{\prime} \mathrm{W}$ & $33^{\circ} 58.850^{\prime} \mathrm{N}$ & $37^{\circ} 16.551^{\prime} \mathrm{W}$ \\
\hline POS536_0_Underway-2 & 01.09 .2019 & $18: 00$ & I-J & $33^{\circ} 08.913^{\prime} \mathrm{N}$ & $37^{\circ} 00.265^{\prime} \mathrm{W}$ & $33^{\circ} 14.966^{\prime} \mathrm{N}$ & $37^{\circ} 00.070^{\prime} \mathrm{W}$ \\
\hline POS536_0_Underway-2 & 01.09 .2019 & 19:00 & I-J & $33^{\circ} 15.029^{\prime} \mathrm{N}$ & $37^{\circ} 00.070^{\prime} \mathrm{W}$ & $33^{\circ} 21.646^{\prime} \mathrm{N}$ & $37^{\circ} 00.150^{\prime} \mathrm{W}$ \\
\hline 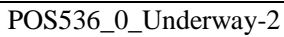 & 01.09 .2019 & $20: 00$ & I-J & $33^{\circ} 21.691^{\prime} \mathrm{N}$ & $37^{\circ} 00.151^{\prime} \mathrm{W}$ & $33^{\circ} 28.511^{\prime} \mathrm{N}$ & $37^{\circ} 00.222^{\prime} \mathrm{W}$ \\
\hline POS536_0_Underway-2 & 03.09 .2019 & $12: 00$ & $\mathrm{~J}-\mathrm{K}$ & $33^{\circ} 21.033^{\prime} \mathrm{N}$ & $36^{\circ} 57.621^{\prime} \mathrm{W}$ & $33^{\circ} 21.093^{\prime} \mathrm{N}$ & $36^{\circ} 48.641^{\prime} \mathrm{W}$ \\
\hline POS536_0_Underway-2 & 03.09 .2019 & $13: 00$ & $\mathrm{~J}-\mathrm{K}$ & $33^{\circ} 21.093^{\prime} \mathrm{N}$ & $36^{\circ} 48.576^{\prime} \mathrm{W}$ & $33^{\circ} 21.173^{\prime} \mathrm{N}$ & $36^{\circ} 39.318^{\prime} \mathrm{W}$ \\
\hline POS536_0_Underway-2 & 03.09 .2019 & $15: 30$ & $\mathrm{~J}-\mathrm{K}$ & $33^{\circ} 21.281^{\prime} \mathrm{N}$ & $36^{\circ} 25.226^{\prime} \mathrm{W}$ & $33^{\circ} 21.357^{\prime} \mathrm{N}$ & $36^{\circ} 16.026^{\prime} \mathrm{W}$ \\
\hline POS536_0_Underway-2 & 03.09 .2019 & $16: 30$ & $\mathrm{~J}-\mathrm{K}$ & $33^{\circ} 21.357^{\prime} \mathrm{N}$ & $36^{\circ} 15.966^{\prime} \mathrm{W}$ & $33^{\circ} 20.937^{\prime} \mathrm{N}$ & $36^{\circ} 05.870^{\prime} \mathrm{W}$ \\
\hline 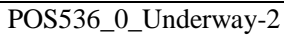 & 03.09 .2019 & 18:00 & $\mathrm{J}-\mathrm{K}$ & $33^{\circ} 20.557^{\prime} \mathrm{N}$ & $36^{\circ} 01.258^{\prime} \mathrm{W}$ & $33^{\circ} 19.734^{\prime} \mathrm{N}$ & $35^{\circ} 51.202^{\prime} \mathrm{W}$ \\
\hline $\begin{array}{l}\text { POS536_0_Underway-2 } \\
\end{array}$ & 03.09 .2019 & 19:00 & $\mathrm{J}-\mathrm{K}$ & $33^{\circ} 19.726^{\prime} \mathrm{N}$ & $35^{\circ} 51.103^{\prime} \mathrm{W}$ & $33^{\circ} 18.902^{\prime} \mathrm{N}$ & $35^{\circ} 40.989^{\prime} \mathrm{W}$ \\
\hline
\end{tabular}




\subsection{Neuston net trawls}

(Grace Lindsay Walls, Erik Borchert, Jenny Friedrich, Nicolas Ory (PI))

\section{Research objectives and summary}

Microplastics (> $300 \mu \mathrm{m}$ ) floating at the sea surface within the working area and inside oceanic eddies were sampled with a neuston catamaran trawl.

The collected material was screened for plastic debris by microscopic inspection on board of RV Poseidon and plastic particles were picked and stored for later polymer identification in laboratories at GEOMAR using Raman micro-spectroscopy. This will provide information about the abundance and composition of microplastics at the sea surface, which will complement the data gained by sampling the water column and the seafloor. Neuston trawls will also be screened for macroplastic fragments, on which very likely microbial biofilms have established during the time they spent at sea.

These microbial communities will be analysed with regard to their composition and potential bioactivity.

It was shown that some bacteria and fungi are able to produce enzymes/biocatalysts that are able to degrade synthetic polymers. Nonetheless to date only a handful of enzymes that can degrade PET and PU are known and for most other man-made polymers no enzymes have been found. Exploiting environmental sources, such as bacterial enzymes, will be a crucial step in reducing plastic pollution.

\section{Description of the gear}

A neuston catamaran outfitted with a microplastic trawl net (mesh size $300 \mu \mathrm{m}$, mouth opening $70 \mathrm{~cm}$ x $40 \mathrm{~cm}$, Figure 5.2-2a.) was used to collect microplastics at the sea surface. The net opening was equipped with a flowmeter to measure the volume of water that was filtered by the net during one trawl. Furthermore, we attached a GoPro camera to observe the average height to which the net opening was filled with water during the trawls. The catamaran was towed portside of the ship, with the current wind direction and outside of the ships wake at 4 knots for 20 minutes. If sampling was conducted inside a very dense patch of floating Sargassum sp. (Figure 5.2-1), trawl time was reduced to 10 minutes to minimize the amount debris collected outside of the codend and to reduce the risk of getting the flowmeter entangled in the algal material. 


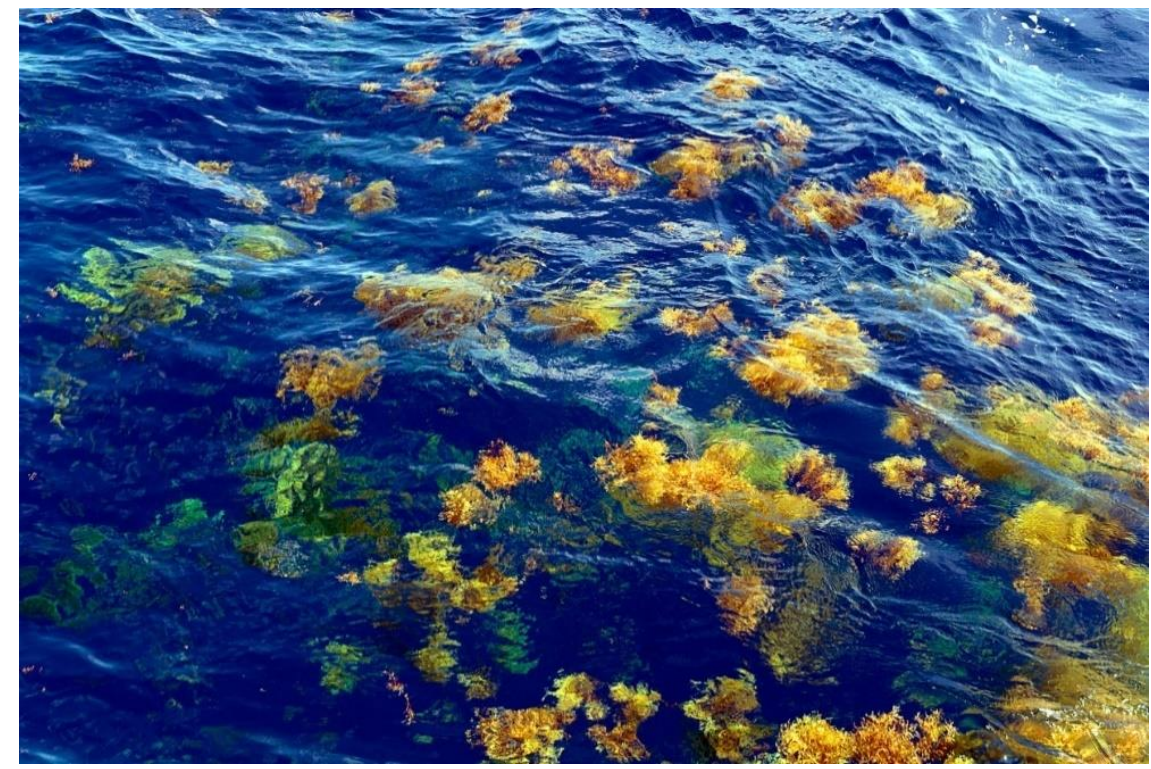

Figure 5.2-1 A dense patch of floating Sargassum sp. Photo: Mark Lenz.

After each tow, the body of the net was thoroughly cleaned from the outside using a seawater supplied deck hose to push all particles and debris into the codend, while avoiding contaminating the sample with potential particles from inside the hose. The content of the codend was collected and Sargassum thalli were thoroughly rinsed with MilliQ and checked for monofilaments or microplastic particles before being discarded (Fig 5.2-2b). The remainder was sieved through a $100 \mu \mathrm{m}$ mesh sieve and stored in a $200 \mathrm{ml}$ Kautex bottle preserved in 70 $\%$ ethanol for further analysis.

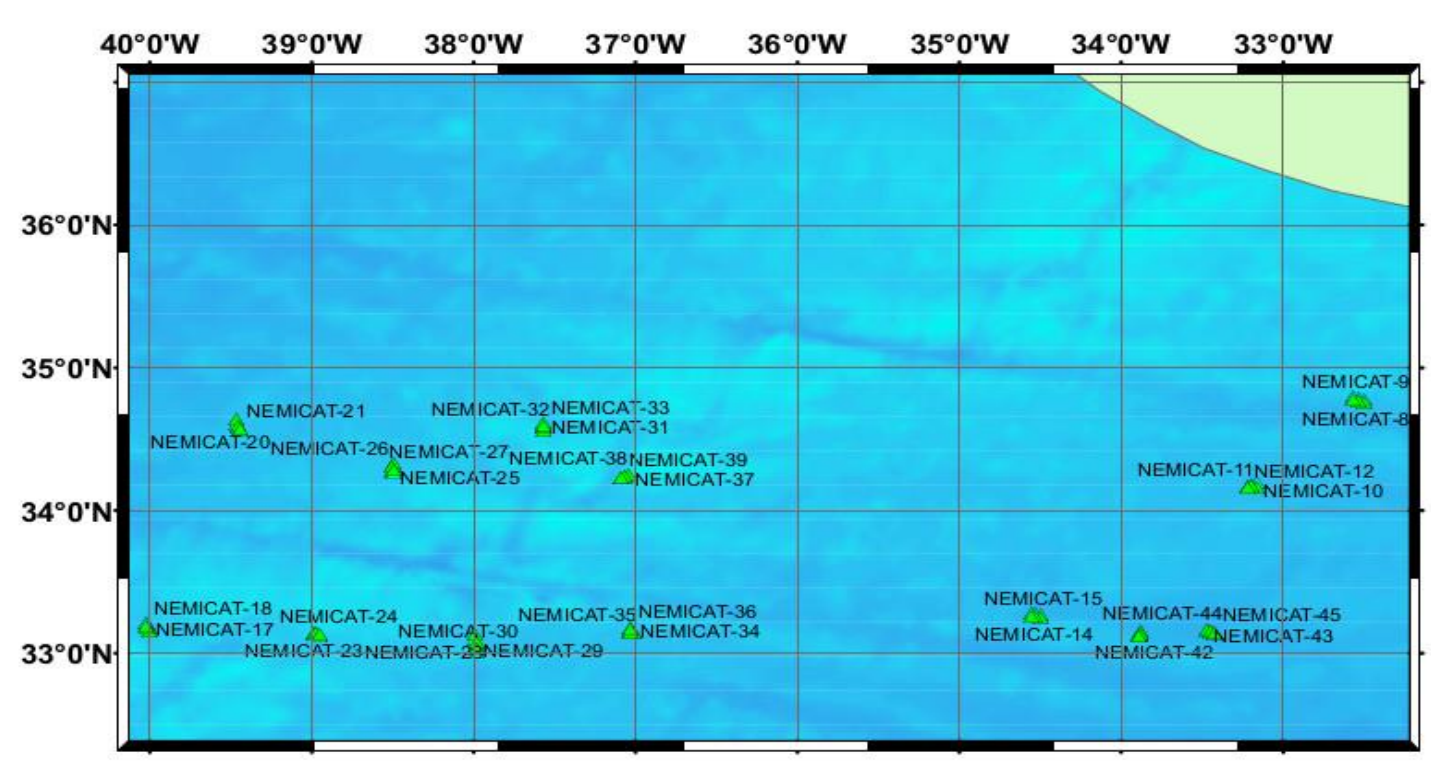

Figure 5.2-2 Neuston trawls conducted during POS536. 
Samples sorted at sea were visually inspected under a binocular. Microplastics found were removed and stored in Eppendorf vials in $70 \%$ ethanol, while information about the shape, size, and color of each fragment was recorded (Figure 5.2-3).

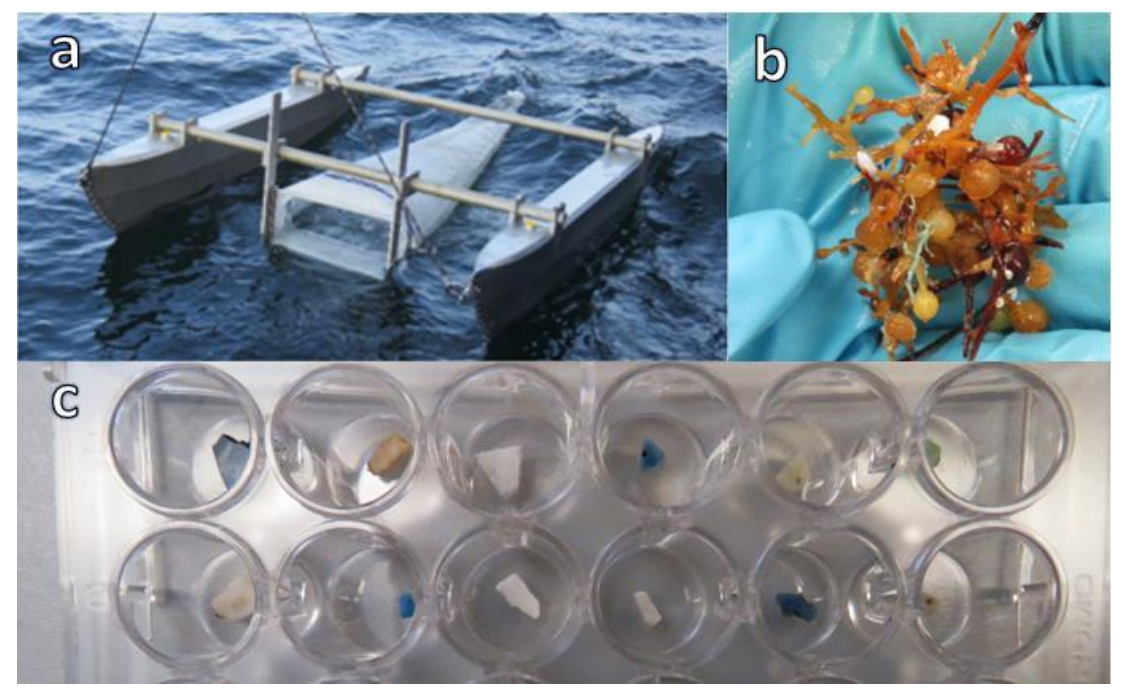

Figure 5.2-3 a) Neuston catamaran trawl outfitted with a microplastic trawl net $(300 \mu \mathrm{m})$.

b) Thallus fragment of Sargassum sp. containing multiple microplastic particles (white) and monofilaments (green). c) Microplastics sepa-rated out of one haul awaiting documentation and storage.

\section{Sample preparation and analysis at GEOMAR}

The picked plastic fragments will be analysed with regard to their polymer types in laboratories at GEOMAR using ATR Raman micro-spectroscopy.

\subsubsection{Analysis of microbial communities on macroplastics}

Samples retrieved with the neuston catamaran microplastic trawl were also screened for macroplastic fragments. All plastic fragments $\geq 0.5 \mathrm{~mm}$ were removed from the trawl sample and conserved in a saturated ammonium sulphate solution (Figure 5.2-4). 


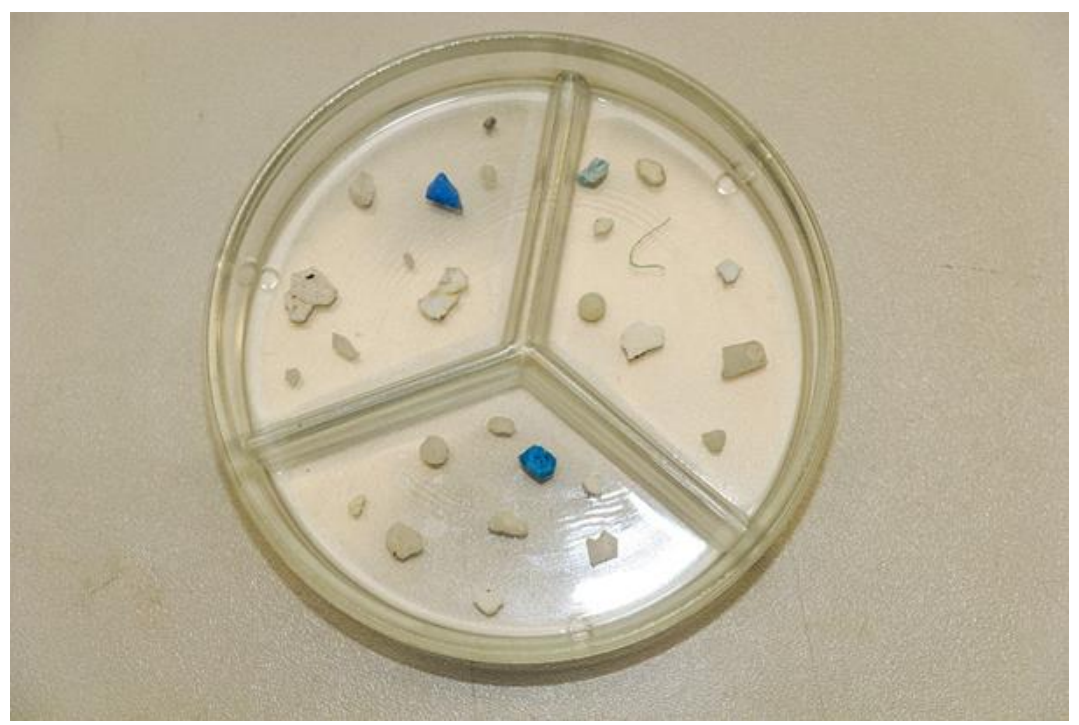

Figure 5.2-4 Plastic fragments and pre-production pellets that were picked from one neuston trawl. Photo: Mark Lenz.

This solution precipitates all proteins and therefore prevents DNA and RNA degradation for an elongated time, even at room temperature. The fragments will be subsequently used for microbiological/bioinformatic analysis via the use of state-of-the-art sequencing techniques to identify the bacterial communities inhabiting the surfaces of plastic items floating in the open ocean. Biofilms will be characterized by $16 \mathrm{~S}$ rRNA sequencing, specifically targeting the V3/V4 region of the $16 \mathrm{~S}$ rRNA gene. This sequencing will give a information about the structure of the communities that established on floating particles in the North Atlantic garbage patch.

At GEOMAR, all fragments will further be investigated with Attenuated Total Reflectance Fourier Transform Infrared Spectroscopy (ATR-FTIR) to identify the synthetic polymers of which the fragments were made of. For the analyses of structural changes of the particles' surfaces, which possibly are related to biodegradation processes, nearfield FTIR microscopy (NEASPEC) will be applied. Ultimately, the retrieved metagenomic DNA will also be used for metagenomic sequencing to get an in depth understanding of the enzymatic capabilities of the inhabiting bacterial communities. 


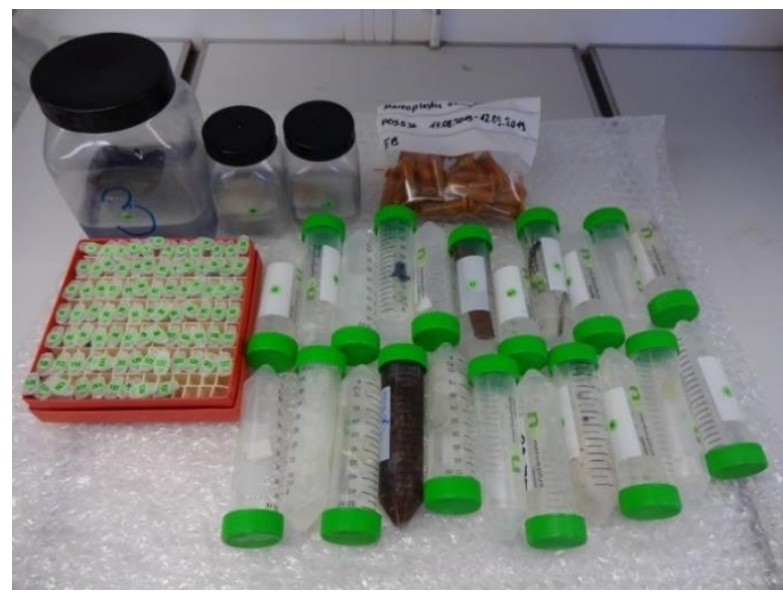

Figure 5.2-5 137 macroplastic fragments were retrieved from 45 neuston catamaran trawls and preserved for later analysis in an ammomium sulphate solution during the POS536 cruise. Photo: Erik Borchert.

Table 5.2 Stations at which neuston trawls were performed during POS536.

\begin{tabular}{|c|c|c|c|c|c|}
\hline D-Ship & Date & Time (UTC) & Area & Latitude (start) & Longitude (start) \\
\hline POS536_1-1 & 18.08 .2019 & $18: 17$ & $\mathrm{~A}$ & $35^{\circ} 34.98^{\prime} \mathrm{N}$ & $31^{\circ} 04,93^{\prime} \mathrm{W}$ \\
\hline POS536_2-1 & 18.08 .2019 & $18: 56$ & A & $35^{\circ} 35,021^{\prime} \mathrm{N}$ & $31^{\circ} 07,41^{\prime} \mathrm{W}$ \\
\hline POS536_3-1 & 18.08 .2019 & 19:33 & A & $35^{\circ} 34.26^{\prime} \mathrm{N}$ & $31^{\circ} 09,18^{\prime} \mathrm{W}$ \\
\hline POS536_4-1 & 18.08 .2019 & $22: 58$ & A & $35^{\circ} 22.50^{\prime} \mathrm{N}$ & $31^{\circ} 37,54^{\prime} \mathrm{W}$ \\
\hline POS536_5-1 & 18.08 .2019 & $23: 47$ & A & $35^{\circ} 22.26^{\prime} \mathrm{N}$ & $31^{\circ} 39,52^{\prime} \mathrm{W}$ \\
\hline POS536_6-1 & 18.08 .2019 & $00: 30$ & A & $35^{\circ} 22.31^{\prime} \mathrm{N}$ & $31^{\circ} 40,83^{\prime} \mathrm{W}$ \\
\hline POS536_7-1 & 19.08 .2019 & $08: 27$ & $\mathrm{~A}$ & $34^{\circ} 45.20^{\prime} \mathrm{N}$ & $32^{\circ} 30,15^{\prime} \mathrm{W}$ \\
\hline POS536_8-1 & 19.08.2019 & 09:07 & A & $34^{\circ} 46.04^{\prime} \mathrm{N}$ & $32^{\circ} 32,12^{\prime} \mathrm{W}$ \\
\hline POS536_9-1 & 19.08.2019 & 09:45 & A & $34^{\circ} 46.61^{\prime} \mathrm{N}$ & $32^{\circ} 34,25^{\prime} \mathrm{W}$ \\
\hline POS536_10-1 & 19.08.2019 & $15: 31$ & A & $34^{\circ} 10.10^{\prime} \mathrm{N}$ & $33^{\circ} 09,99^{\prime} \mathrm{W}$ \\
\hline POS536_11-1 & 19.08 .2019 & 16:09 & A & $34^{\circ} 10.16^{\prime} \mathrm{N}$ & $33^{\circ} 11,56^{\prime} \mathrm{W}$ \\
\hline POS536_12-1 & 19.08.2019 & $16: 48$ & A & $34^{\circ} 09.43^{\prime} \mathrm{N}$ & $33^{\circ} 13.34^{\prime} \mathrm{W}$ \\
\hline POS536_13-1 & 20.08 .2019 & $02: 29$ & B & $33^{\circ} 15.19^{\prime} \mathrm{N}$ & $034^{\circ} 29.97^{\prime} \mathrm{W}$ \\
\hline POS536_14-1 & 20.08 .2019 & 03:09 & B & $33^{\circ} 15.31^{\prime} \mathrm{N}$ & $034^{\circ} 31.90^{\prime} \mathrm{W}$ \\
\hline POS536_15-1 & 20.08 .2019 & 03:51 & B & $33^{\circ} 15.70^{\prime} \mathrm{N}$ & $034^{\circ} 33.47^{\prime} \mathrm{W}$ \\
\hline POS536_30-1 & 23.08 .2019 & 00:02 & $\mathrm{C}$ & $33^{\circ} 09.37^{\prime} \mathrm{N}$ & $39^{\circ} 59.89^{\prime} \mathrm{W}$ \\
\hline POS536_31-1 & 23.08 .2019 & $00: 40$ & $\mathrm{C}$ & $33^{\circ} 10.55^{\prime} \mathrm{N}$ & $40^{\circ} 00.77^{\prime} \mathrm{W}$ \\
\hline POS536_32-1 & 23.08 .2019 & $01: 19$ & $\mathrm{C}$ & $33^{\circ} 11.43^{\prime} \mathrm{N}$ & $40^{\circ} 01.55^{\prime} \mathrm{W}$ \\
\hline POS536_45-1 & 24.08 .2019 & $15: 35$ & $\mathrm{D}$ & $34^{\circ} 38.36^{\prime} \mathrm{N}$ & $39^{\circ} 27.74^{\prime} \mathrm{W}$ \\
\hline POS536_46-1 & 24.08 .2019 & $16: 09$ & $\mathrm{D}$ & $34^{\circ} 36.10^{\prime} \mathrm{N}$ & $39^{\circ} 27.34^{\prime} \mathrm{W}$ \\
\hline POS536_47-1 & 24.08 .2019 & $16: 36$ & $\mathrm{D}$ & $34^{\circ} 34.36^{\prime} \mathrm{N}$ & $39^{\circ} 26.84^{\prime} \mathrm{W}$ \\
\hline POS536_61-1 & 26.08 .2019 & $02: 44$ & $\mathrm{E}$ & $33^{\circ} 08.676^{\prime} \mathrm{N}$ & $038^{\circ} 59.411^{\prime} \mathrm{W}$ \\
\hline POS536_62-1 & 26.08 .2019 & $03: 24$ & $\mathrm{E}$ & $33^{\circ} 08.515^{\prime} \mathrm{N}$ & $038^{\circ} 58.179^{\prime} \mathrm{W}$ \\
\hline POS536_63-1 & 26.08 .2019 & 04:04 & $\mathrm{E}$ & $33^{\circ} 08.209^{\prime} \mathrm{N}$ & $038^{\circ} 57.089^{\prime} \mathrm{W}$ \\
\hline POS536_74-1 & 28.08 .2019 & 13:00 & $\mathrm{F}$ & $34^{\circ} 20.106^{\prime} \mathrm{N}$ & $038^{\circ} 29.931^{\prime} \mathrm{W}$ \\
\hline POS536_75-1 & 28.08 .2019 & $13: 38$ & $\mathrm{~F}$ & $34^{\circ} 18.739^{\prime} \mathrm{N}$ & $038^{\circ} 30.039^{\prime} \mathrm{W}$ \\
\hline POS536_76-1 & 28.08 .2019 & 14:19 & $\mathrm{F}$ & $34^{\circ} 17.456^{\prime} \mathrm{N}$ & $038^{\circ} 29.632^{\prime} \mathrm{W}$ \\
\hline POS536_87-1 & 29.08 .2019 & $14: 40$ & G & $33^{\circ} 07.944^{\prime} \mathrm{N}$ & $037^{\circ} 59.550^{\prime} \mathrm{W}$ \\
\hline POS536_88-1 & 29.08 .2019 & $15: 20$ & $\mathrm{G}$ & $33^{\circ} 04.964^{\prime} \mathrm{N}$ & $037^{\circ} 59.046^{\prime} \mathrm{W}$ \\
\hline POS536_89-1 & 29.08 .2019 & $15: 58$ & G & $33^{\circ} 02.236^{\prime} \mathrm{N}$ & $037^{\circ} 58.635^{\prime} \mathrm{W}$ \\
\hline POS536_106-1 & 31.08 .2019 & 13:00 & $\mathrm{H}$ & $34^{\circ} 33.939^{\prime} \mathrm{N}$ & $037^{\circ} 33.988^{\prime} \mathrm{W}$ \\
\hline POS536_107-1 & 31.08 .2019 & $13: 39$ & $\mathrm{H}$ & $34^{\circ} 35.127^{\prime} \mathrm{N}$ & $037^{\circ} 34.108^{\prime} \mathrm{W}$ \\
\hline POS536_108-1 & 31.08 .2019 & $14: 18$ & $\mathrm{H}$ & $34^{\circ} 36.097^{\prime} \mathrm{N}$ & $037^{\circ} 34.247^{\prime} \mathrm{W}$ \\
\hline POS536_113-1 & 01.09 .2019 & $05: 42$ & I & $33^{\circ} 08.943^{\prime} \mathrm{N}$ & $037^{\circ} 00.766^{\prime} \mathrm{W}$ \\
\hline POS536_114-1 & 01.09 .2019 & $06: 11$ & I & $33^{\circ} 08.686^{\prime} \mathrm{N}$ & $037^{\circ} 02.161^{\prime} \mathrm{W}$ \\
\hline POS536_115-1 & 01.09 .2019 & $06: 36$ & I & $33^{\circ} 10.288^{\prime} \mathrm{N}$ & $037^{\circ} 01.954^{\prime} \mathrm{W}$ \\
\hline
\end{tabular}




\begin{tabular}{|l|l|c|c|c|c|}
\hline D-Ship & Date & Time (UTC) & Area & Latitude (start) & Longitude (start) \\
\hline POS536_130-1 & 02.09 .2019 & $13: 33$ & $\mathrm{~J}$ & $34^{\circ} 15.032^{\prime} \mathrm{N}$ & $037^{\circ} 02.846^{\prime} \mathrm{W}$ \\
\hline POS536_131-1 & 02.09 .2019 & $14: 13$ & $\mathrm{~J}$ & $34^{\circ} 14.586^{\prime} \mathrm{N}$ & $037^{\circ} 04.179^{\prime} \mathrm{W}$ \\
\hline POS536_132-1 & 02.09 .2019 & $14: 53$ & $\mathrm{~J}$ & $34^{\circ} 14.116^{\prime} \mathrm{N}$ & $037^{\circ} 05.377^{\prime} \mathrm{W}$ \\
\hline POS536_141-1 & 04.09 .2019 & $14: 46$ & $\mathrm{~K}$ & $33^{\circ} 09.342^{\prime} \mathrm{N}$ & $033^{\circ} 52.645^{\prime} \mathrm{W}$ \\
\hline POS536_142-1 & 04.09 .2019 & $15: 08$ & $\mathrm{~K}$ & $33^{\circ} 08.417^{\prime} \mathrm{N}$ & $033^{\circ} 53.058^{\prime} \mathrm{W}$ \\
\hline POS536_143-1 & 04.09 .2019 & $15: 34$ & $\mathrm{~K}$ & $33^{\circ} 07.543^{\prime} \mathrm{N}$ & $033^{\circ} 53.676^{\prime} \mathrm{W}$ \\
\hline POS536_145-1 & 04.09 .2019 & $22: 11$ & $\mathrm{~K}$ & $33^{\circ} 09.908^{\prime} \mathrm{N}$ & $033^{\circ} 28.410^{\prime} \mathrm{W}$ \\
\hline POS536_146-1 & 04.09 .2019 & $22: 35$ & $\mathrm{~K}$ & $33^{\circ} 09.286^{\prime} \mathrm{N}$ & $033^{\circ} 26.872^{\prime} \mathrm{W}$ \\
\hline POS536_147-1 & 04.09 .2019 & $23: 01$ & $\mathrm{~K}$ & $33^{\circ} 08.620^{\prime} \mathrm{N}$ & $033^{\circ} 25.227^{\prime} \mathrm{W}$ \\
\hline
\end{tabular}

\subsection{Vertical sampling of the water column with the WP2 plankton net}

(Sarah-Marie Kröger, Jenny Friedrich, Thea Hamm, Ulrike Panknin, Mark Lenz (PI), Jamileh Javid (PI))

\section{Research objectives and summary}

Most of the available data on the abundance and composition of plastic debris in the open ocean stem from samplings that used sea surface trawls (e.g. Manta trawl), while very few studies quantified plastic debris by sampling in different water depths. Plastic-biota interactions in the open ocean comprise the ingestion of particles by pelagic or benthic organisms, their colonization by biofoulers (bacteria to metazoans) and their entrapment in mucus that was released by gelatinous plankton organisms. All of these processes presumably play a role in the vertical transport of plastic debris from the ocean surface to the deep-sea and further into deepsea sediments, but very few empirical data exist that document their action.

The use of the WP2 net allowed to collect microplastic particles as well as planktonic organisms that ingested or trapped microplastics on their sticky surfaces across different parts of the water column.

\section{Description of the gear}

The WP (Working Party) 2 is a vertically or horizontally operated oceanographic plankton net with a long funnel shaped net bag that allows to assess the vertical and diagonal distribution of phyto - or zooplankton in the water column.

On this cruise, the model "WP2-closing net" by HYDRO-BIOS Kiel was used for vertical hauls only (Figure 5.3-1). The net closing mechanism was not installed and therefore the hauls collected material over the entire water column that was sampled.

The net bag is made of nylon and has a length of $2.6 \mathrm{~m}$ and a mesh size of $100 \mu \mathrm{m}$. The diameter of the net mouth is $57 \mathrm{~cm}$. The stainless-steel ring has a diameter of $60 \mathrm{~cm}$ and the WP2 net was fastened to the ring with a zipping system. For easy retrieval, the sampled material is collected in a removable collector with a mesh-window (mesh size $100 \mu \mathrm{m}$ ) that allows the water to flow out. 


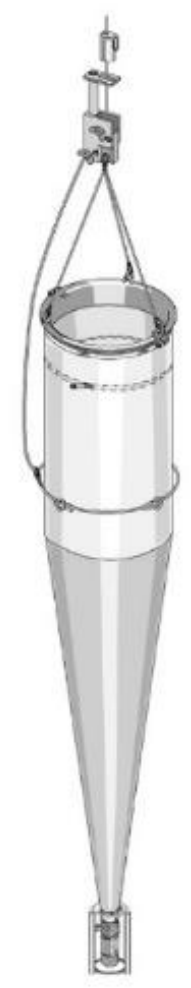

Figure 5.3-1 The WP2 plankton net (Image: HYDRO-BIOS Kiel).

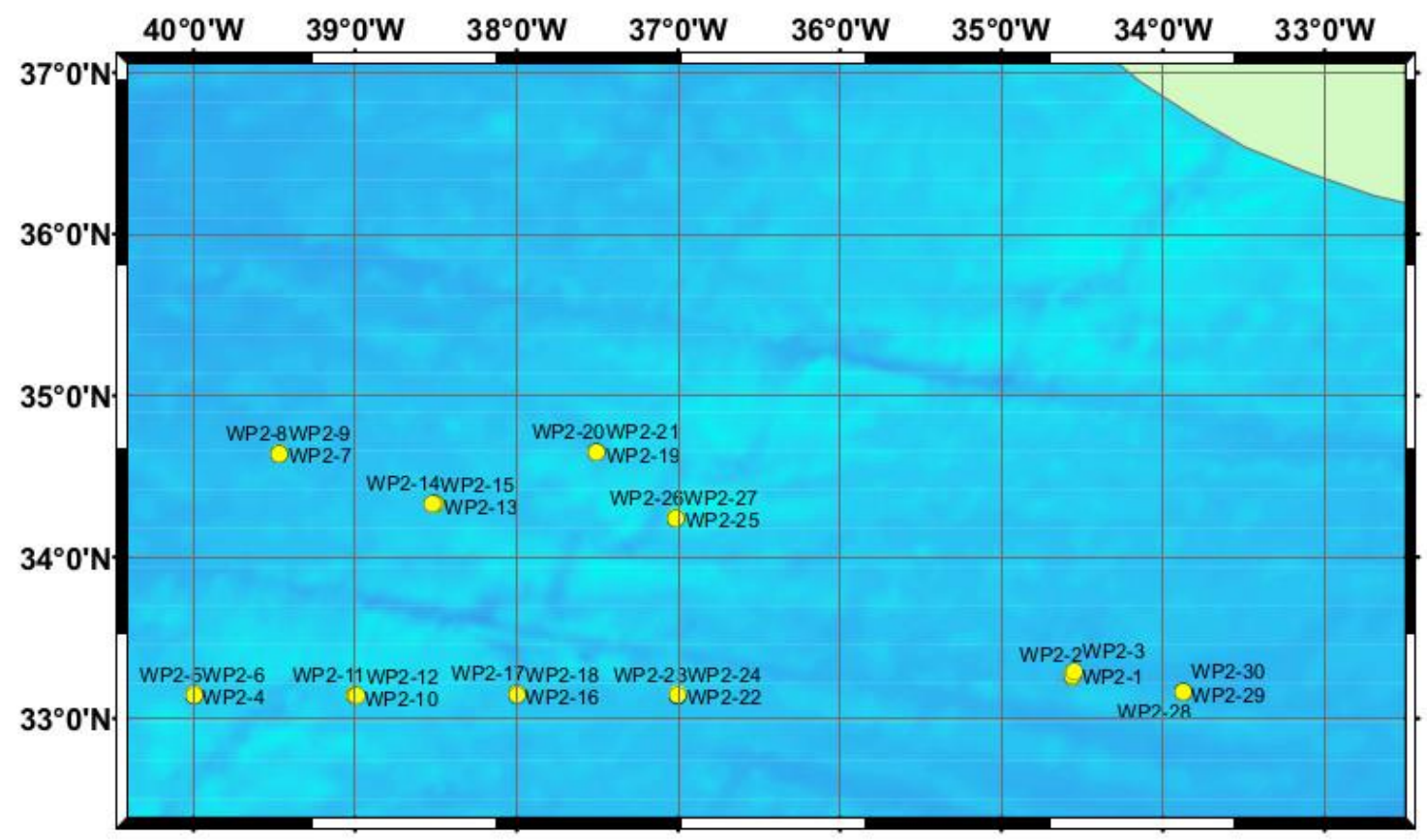

Figure 5.3-2 WP2 plankton net hauls done during POS536.

The collector was attached to a stainless-steel net bucket frame and both were attached to the WP2 steel ring with three ropes to prevent the detachment of the collector from the net bag while retrieving the net. 
The net mouth was equipped with a mechanical flowmeter (HYDRO-BIOS Kiel) with backrun-stop, to determine the water flow during the sampling process. Furthermore, a $12 \mathrm{~kg}$ metal weight was attached to the steel frame with ropes to ensure a correct orientation of the net during deployments. For a later monitoring of the actual deployment depth, two depth loggers (Star Oddi) were attached to the steel ring.

At a total of 10 stations ( $\mathrm{B}-\mathrm{K})$, the WP2 was deployed for three times, while each time it was lowered to one of three depth levels, i.e. $500 \mathrm{~m}, 1000 \mathrm{~m}$ and $1500 \mathrm{~m}$, at a speed of $0.5 \mathrm{~m} / \mathrm{s}$. Right after reaching the sampling depth, the net was heaved again with a speed of $1 \mathrm{~m} / \mathrm{s}$. Before and after each deployment, the flowmeter was read and protocolled.

When the net was on deck again, it was rinsed with seawater that was previously filtered through a $20 \mu \mathrm{m}$ filter cartridge (Knaub Trading GmbH \& Co. KG, Bad Salzuflen). For this, a filter cartridge cascade was connected to one of the vessel's sea water supply systems. The content of the collector, which was attached to the end of the net bag, was rinsed into an aluminium pot by the use of PFA-squeeze bottles that were filled with pre-filtered seawater (20 $\mu \mathrm{m})$. Between the deployments, the net was rinsed with pre-filtered seawater $(20 \mu \mathrm{m})$ supplied by a hose.

\section{Sampling of gelatinous plankton organisms}

Gelatinous plankton organisms were collected from all WP2 hauls (stations B-K) and from all Bongo trawls (station B- K). In total, 812 specimens were picked, sorted and measured. They were stored in 247 containers (plastic bags and Eppendorf vials) and preserved in an $-20^{\circ} \mathrm{C}$ freezer. A picture database of every sampled organism was also created.

On most stations the processing of the samples directly followed the net hauls. Larger Jellies were picked directly from the tin bucket with stainless-steel tweezers. The remaining content of the collectors was sieved through a $175 \mu \mathrm{m}$ sieve and gelatinous organisms were picked from the mesh. Blanks of all potential plastic contamination sources were also sampled.

Table 5.3 Stations at which WP2 net samples were collected during POS536.

\begin{tabular}{|c|c|c|c|c|c|c|}
\hline D-Ship & Date & Time (UTC) & Area & Latitude & Longitude & Depth (m) \\
\hline $\begin{array}{l}\text { POS536_19-1 } \\
\end{array}$ & 20.08 .2019 & 08:30 & B & $33^{\circ} 15.70^{\prime} \mathrm{N}$ & $034^{\circ} 33.49^{\prime} \mathrm{W}$ & 500 \\
\hline POS536_20-1 & 20.08 .2019 & 09:10 & B & $33^{\circ} 16.47^{\prime} \mathrm{N}$ & $034^{\circ} 33.40^{\prime} \mathrm{W}$ & 1000 \\
\hline POS536_21-1 & 20.08 .2019 & 10:03 & B & $33^{\circ} 17.46^{\prime} \mathrm{N}$ & $034^{\circ} 33.02^{\prime} \mathrm{W}$ & 1500 \\
\hline POS536_36-1 & 23.08 .2019 & $06: 17$ & $\mathrm{C}$ & $33^{\circ} 09.13^{\prime} \mathrm{N}$ & $39^{\circ} 59.88^{\prime} \mathrm{W}$ & 550 \\
\hline POS536_37-1 & 23.08 .2019 & 06:54 & $\mathrm{C}$ & $33^{\circ} 08.81^{\prime} \mathrm{N}$ & $39^{\circ} 59.91^{\prime} \mathrm{W}$ & 1150 \\
\hline POS536_38-1 & 23.08 .2019 & $07: 56$ & $\mathrm{C}$ & $33^{\circ} 08.96^{\prime} \mathrm{N}$ & $39^{\circ} 59.87^{\prime} \mathrm{W}$ & 1800 \\
\hline POS536_51-1 & 25.08 .2019 & 04:16 & $\mathrm{D}$ & $34^{\circ} 38.674^{\prime} \mathrm{N}$ & $039^{\circ} 27.896^{\prime} \mathrm{W}$ & 500 \\
\hline POS536_52-1 & 25.08 .2019 & 04:49 & $\mathrm{D}$ & $34^{\circ} 38.605^{\prime} \mathrm{N}$ & $039^{\circ} 27.964^{\prime} \mathrm{W}$ & 1000 \\
\hline POS536_53-1 & 25.08 .2019 & 05:48 & $\mathrm{D}$ & $34^{\circ} 38.535^{\prime} \mathrm{N}$ & $039^{\circ} 28.062^{\prime} \mathrm{W}$ & 1500 \\
\hline POS536_55-1 & 25.08 .2019 & 19:57 & $\mathrm{E}$ & $33^{\circ} 08.988^{\prime} \mathrm{N}$ & $039^{\circ} 00.004^{\prime} \mathrm{W}$ & 500 \\
\hline POS536_56-1 & 25.08 .2019 & $20: 27$ & $\mathrm{E}$ & $33^{\circ} 08.693^{\prime} \mathrm{N}$ & $038^{\circ} 59.813^{\prime} \mathrm{W}$ & 1000 \\
\hline POS536_57-1 & 25.08 .2019 & $21: 22$ & $\mathrm{E}$ & $33^{\circ} 08.367^{\prime} \mathrm{N}$ & $038^{\circ} 59.443^{\prime} \mathrm{W}$ & 1500 \\
\hline POS536_77-1 & 28.08 .2019 & $15: 28$ & $\mathrm{~F}$ & $34^{\circ} 20.026^{\prime} \mathrm{N}$ & $038^{\circ} 30.081^{\prime} \mathrm{W}$ & 500 \\
\hline POS536_78-1 & 28.08 .2019 & $15: 53$ & $\mathrm{~F}$ & $34^{\circ} 19.910^{\prime} \mathrm{N}$ & $038^{\circ} 30.498^{\prime} \mathrm{W}$ & 1000 \\
\hline POS536_79-1 & 28.08 .2019 & $16: 44$ & $\mathrm{~F}$ & $34^{\circ} 19.644^{\prime} \mathrm{N}$ & $038^{\circ} 31.402^{\prime} \mathrm{W}$ & 1500 \\
\hline POS536_90-1 & 30.08 .2019 & 00:08 & G & $33^{\circ} 09.050^{\prime} \mathrm{N}$ & $037^{\circ} 59.881^{\prime} \mathrm{W}$ & 500 \\
\hline POS536_91-1 & 30.08 .2019 & 00:34 & G & $33^{\circ} 09.035^{\prime} \mathrm{N}$ & $037^{\circ} 59.868^{\prime} \mathrm{W}$ & 1000 \\
\hline
\end{tabular}




\begin{tabular}{|c|c|c|c|c|c|c|}
\hline D-Ship & Date & Time (UTC) & Area & Latitude & Longitude & Depth (m) \\
\hline POS536_92-1 & 30.08 .2019 & $01: 20$ & $\mathrm{G}$ & $33^{\circ} 08.979^{\prime} \mathrm{N}$ & $037^{\circ} 59.857^{\prime} \mathrm{W}$ & 1500 \\
\hline POS536_97-1 & 30.08 .2019 & 18:18 & $\mathrm{H}$ & $34^{\circ} 38.939^{\prime} \mathrm{N}$ & $037^{\circ} 30.134^{\prime} \mathrm{W}$ & 600 \\
\hline POS536_98-1 & 30.08 .2019 & 18:53 & $\mathrm{H}$ & $34^{\circ} 38.886^{\prime} \mathrm{N}$ & $037^{\circ} 30.223^{\prime} \mathrm{W}$ & 1100 \\
\hline POS536_99-1 & 30.08 .2019 & 19:51 & $\mathrm{H}$ & $34^{\circ} 39.055^{\prime} \mathrm{N}$ & $037^{\circ} 30.262^{\prime} \mathrm{W}$ & 1600 \\
\hline POS536_110-1 & 01.09 .2019 & 03:06 & I & $33^{\circ} 09.000^{\prime} \mathrm{N}$ & $036^{\circ} 59.962^{\prime} \mathrm{W}$ & 500 \\
\hline POS536_111-1 & 01.09 .2019 & 03:30 & I & $33^{\circ} 08.933^{\prime} \mathrm{N}$ & $036^{\circ} 59.938^{\prime} \mathrm{W}$ & 1000 \\
\hline POS536_112-1 & 01.09 .2019 & 04:20 & I & $33^{\circ} 08.921^{\prime} \mathrm{N}$ & $037^{\circ} 00.001^{\prime} \mathrm{W}$ & 1500 \\
\hline POS536_122-1 & 02.09 .2019 & 04:04 & $\mathrm{J}$ & $34^{\circ} 14.743^{\prime} \mathrm{N}$ & $037^{\circ} 00.802^{\prime} \mathrm{W}$ & 500 \\
\hline POS536_123-1 & 02.09 .2019 & 04:31 & $\mathrm{J}$ & $34^{\circ} 14.699^{\prime} \mathrm{N}$ & $037^{\circ} 00.918^{\prime} \mathrm{W}$ & 1000 \\
\hline POS536_124-1 & 02.09 .2019 & $05: 23$ & $\mathrm{~J}$ & $34^{\circ} 14.565^{\prime} \mathrm{N}$ & $037^{\circ} 01.095^{\prime} \mathrm{W}$ & 1500 \\
\hline POS536_138-1 & 04.09 .2019 & $11: 55$ & $\mathrm{~K}$ & $33^{\circ} 10.069^{\prime} \mathrm{N}$ & $033^{\circ} 52.525^{\prime} \mathrm{W}$ & 500 \\
\hline POS536_139-1 & 04.09 .2019 & $12: 21$ & K & $33^{\circ} 10.024^{\prime} \mathrm{N}$ & $033^{\circ} 52.538^{\prime} \mathrm{W}$ & 1000 \\
\hline POS536_140-1 & 04.09 .2019 & $13: 15$ & $\mathrm{~K}$ & $33^{\circ} 09.912^{\prime} \mathrm{N}$ & $033^{\circ} 52.510^{\prime} \mathrm{W}$ & 1500 \\
\hline
\end{tabular}

\section{Sample preparation and analysis at GEOMAR and at Odense University (SDU)}

Frozen samples will be freeze dried under contamination-free conditions at the SDU ecotoxicology laboratory. To purify samples, we will apply internal protocols that were used successfully in previous studies.

Samples will be concentrated on cellulose acetate filters to be inspected for microplastic and nanoplastic particles and shapes as well as polymer types will be identified with Raman microspectroscopy. Data will be standardized by comparing the level of microplastic contamination with blank samples as well as collected environmental samples such as water samples.

\subsection{Horizontal water column sampling with the bongo net}

(Thea Hamm, Ulrike Panknin, Mark Lenz (PI))

\section{Research objectives and summary}

Most of the available data on the abundance and composition of plastic debris in the open ocean stem from samplings that used sea surface trawls (e.g. manta trawl), while very few studies quantified plastic debris by sampling in different water depths. Therefore, we know very little about the distribution of, in particular, microplastics across the water column in oceanic waters as well as about the abundance of microplastics in the digestive tracts, the gills and the surface of planktonic organisms. Plastic-biota interactions in the pelagic environment potentially comprise the ingestion of particles, their colonization by biofoulers (bacteria to metazoans), their entrapment in mucus released by gelatinous plankton organisms or their retention in gills. All of these processes could impair the physiological performance as well as the fitness of the affected animals. Furthermore, they presumably play a role in the vertical transport of plastic debris from the ocean surface to the deep-sea and further into deep-sea sediments. The use of the bongo net allowed us to collect microplastic particles as well as planktonic organisms, which may have microplastics in their digestive tract, on their gills or on their body surface, in different layers of the water column. 


\section{Description of the gear}

A bongo net (HYDRO-BIOS Kiel) with a $22 \mathrm{~kg} \mathrm{~V}$-fin depressor and with a $300 \mu \mathrm{m}$ mesh size on both nets was used to sample different water depths (Figure 5.4-1a+b). The bongo net was equipped with two depth loggers (Star Oddi), which recorded the water depth during towing, as well as with a mechanical flowmeter with back-run stop (HYDRO-BIOS Kiel) to measure the water volume that passed through the net bags during deployment. The net bags were rinsed with filtered seawater $(20 \mu \mathrm{m})$ before the first deployment and were again rinsed after each further deployment to wash the retained material into the collectors that were at the end of the net bags. At each station the bongo net was deployed three times to sample in $10 \mathrm{~m}, 100 \mathrm{~m}$ and $300 \mathrm{~m}$ depth for 30 minutes at 2 knots ship speed (Table 5.4-1). We lowered the bongo net with $0.7 \mathrm{~m} / \mathrm{s}$ and hoisted it with $0.5 \mathrm{~m} / \mathrm{s}$ rope speed. After each deployment the ship returned to its initial position.

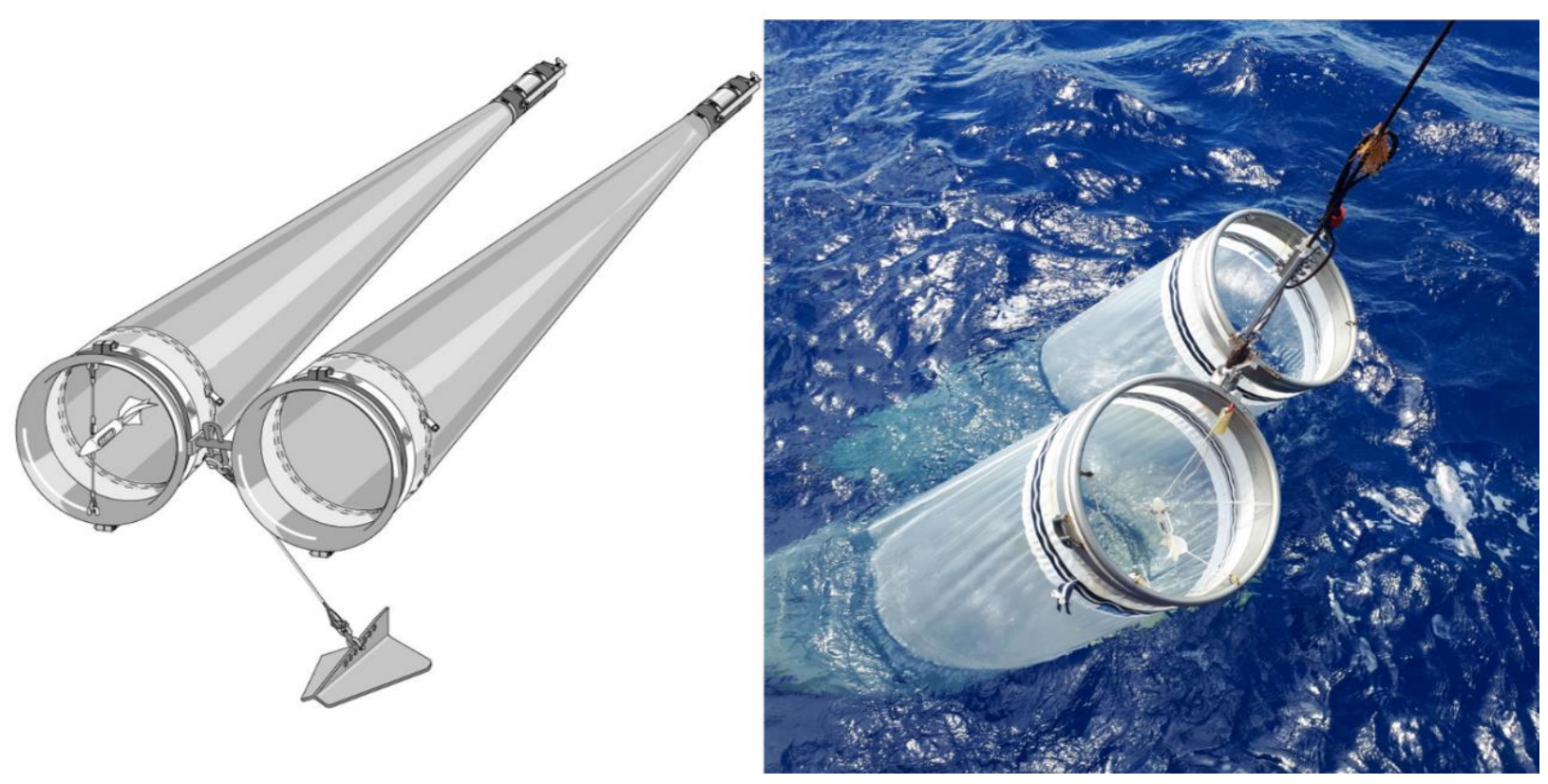

Figure 5.4-1 a) Bongo net with V-fin depressor and flowmeter (Image: HYDRo-BIOS Kiel) and b) during deployment at sea. Photo: Ulrike Panknin.

Table 5.4-1 The bongo net was used for collecting samples in three water depths. The water volume indicated was the volume sampled averaged across all stations.

\begin{tabular}{|l|l|l|l|}
\hline \multicolumn{1}{|c|}{ Depth (m) } & \multicolumn{1}{|c|}{ Average volume (l) } & Towing time (min) \\
\hline $\mathbf{1 0}$ & 30 & 1050472 & 30 \\
\hline $\mathbf{1 0 0}$ & 250 & 1613346 & 30 \\
\hline $\mathbf{3 0 0}$ & 750 & 2189464 & 30 \\
\hline
\end{tabular}

Samples were transferred from the collectors to aluminium pots and then sieved in the laboratory through a $250 \mu \mathrm{m}$ stainless steel sieve. During sieving gelatinous plankton organisms were picked, transferred to glass petri dishes and then frozen for later analysis. Furthermore, 
each sample was visually inspected for microplastic particles and for particularly fragile or conspicuous organisms (Figure 5.4-2 \& Figure 5.4-3). Both were then transferred to petri dishes and photographed under a stereomicroscope. After having returned the photographed objects, the samples were transferred into $500 \mathrm{ml}$ glass containers with a lid and preserved with a formaldehyde solution (4\%).
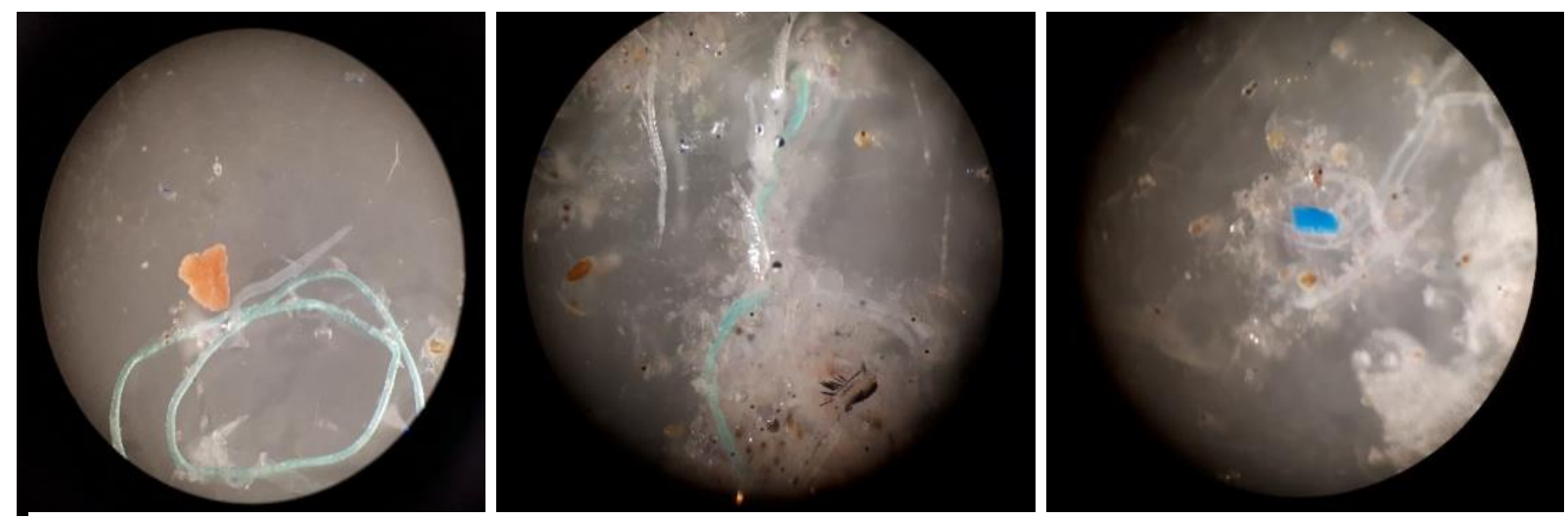

Figure 5.4-2 Potential microplastic particles that were found in the bongo net samples. Photo: Ulrike Panknin.

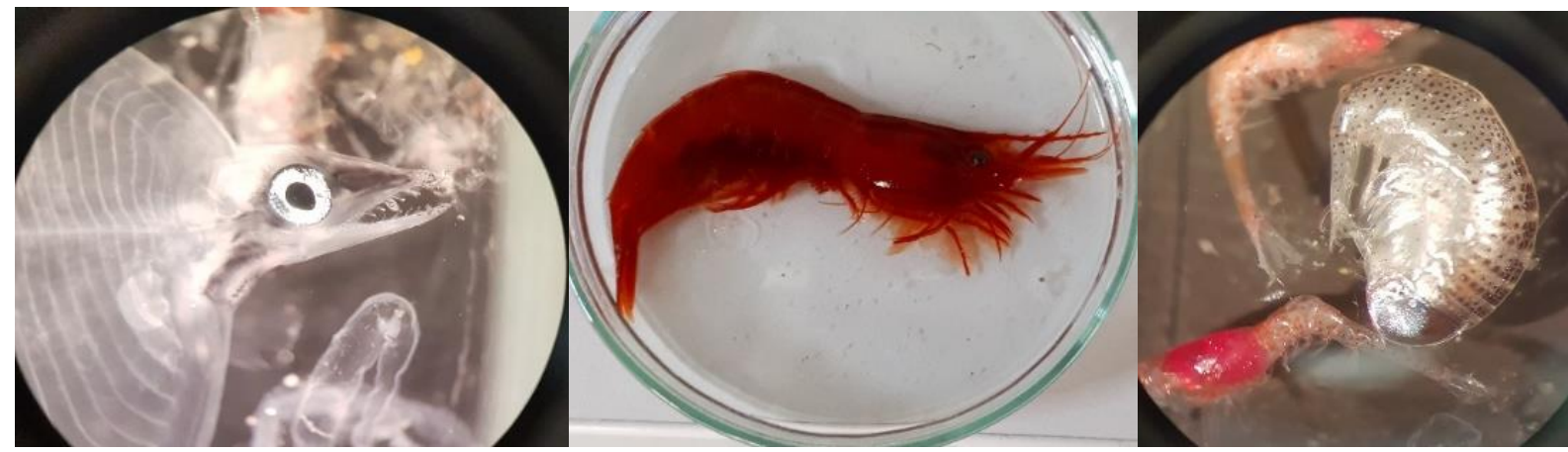

Figure 5.4-3 Plankton organisms that were collected with the bongo net. a) Leptochephalus larva. Photo: Thea Hamm, b) Acantephyra sp. Photo: Ulrike Panknin, and c) Hyperia sp. Photo: Ulrike Panknin.

To avoid the contamination of the samples with plastic particles originating from the used materials, aluminium pots, steel tweezers, glass petri dishes, a metal net and $500 \mathrm{ml}$ glass jars with glass lids were used to handle and store the samples. Only pre-filtered seawater was used to rinse or wash the samples out of the net bags or to transfer them into the storage containers (Figure 5.4-4). Apart from the nylon net bags, the net collector that was made from PV and the PTFE squeeze bottles, the sample material was never in contact with plastic. 


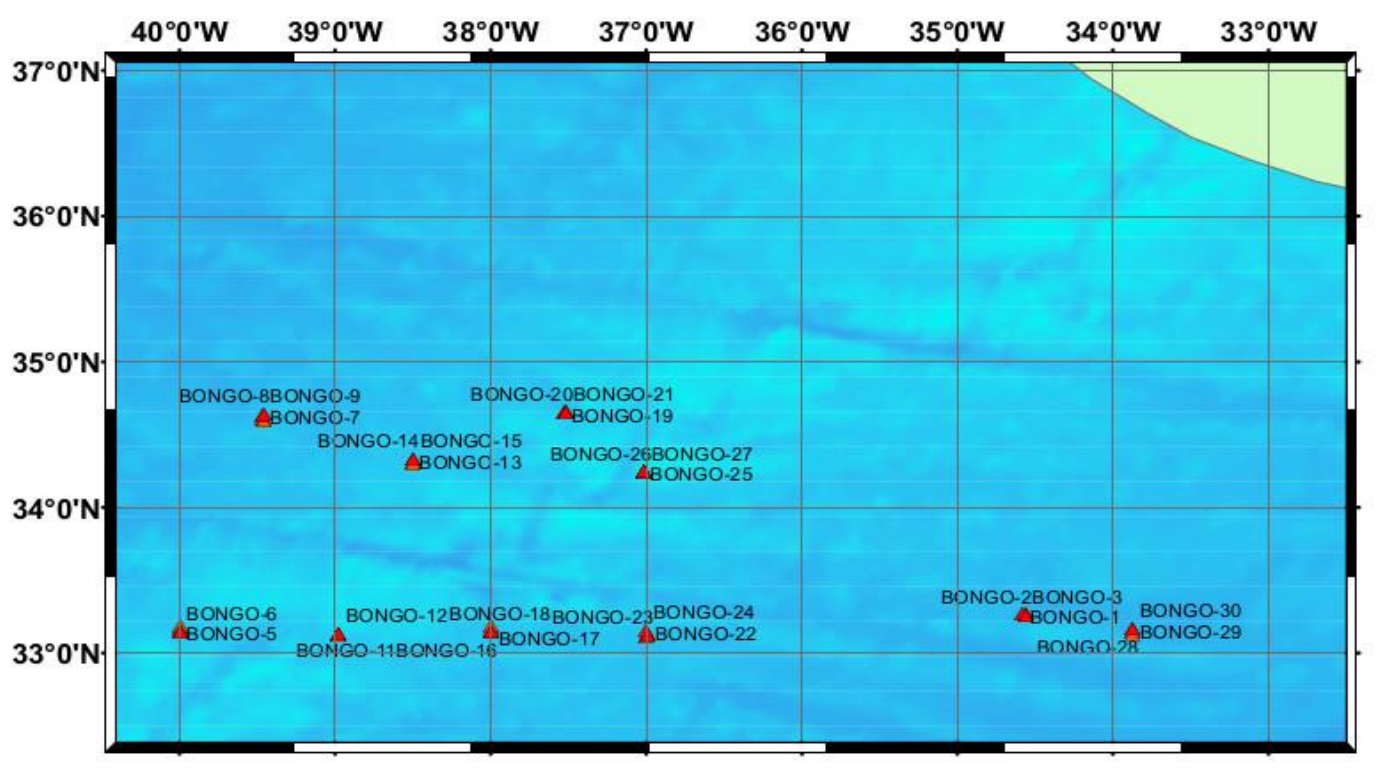

Figure 5.4-4 Bongo net trawls during POS536.

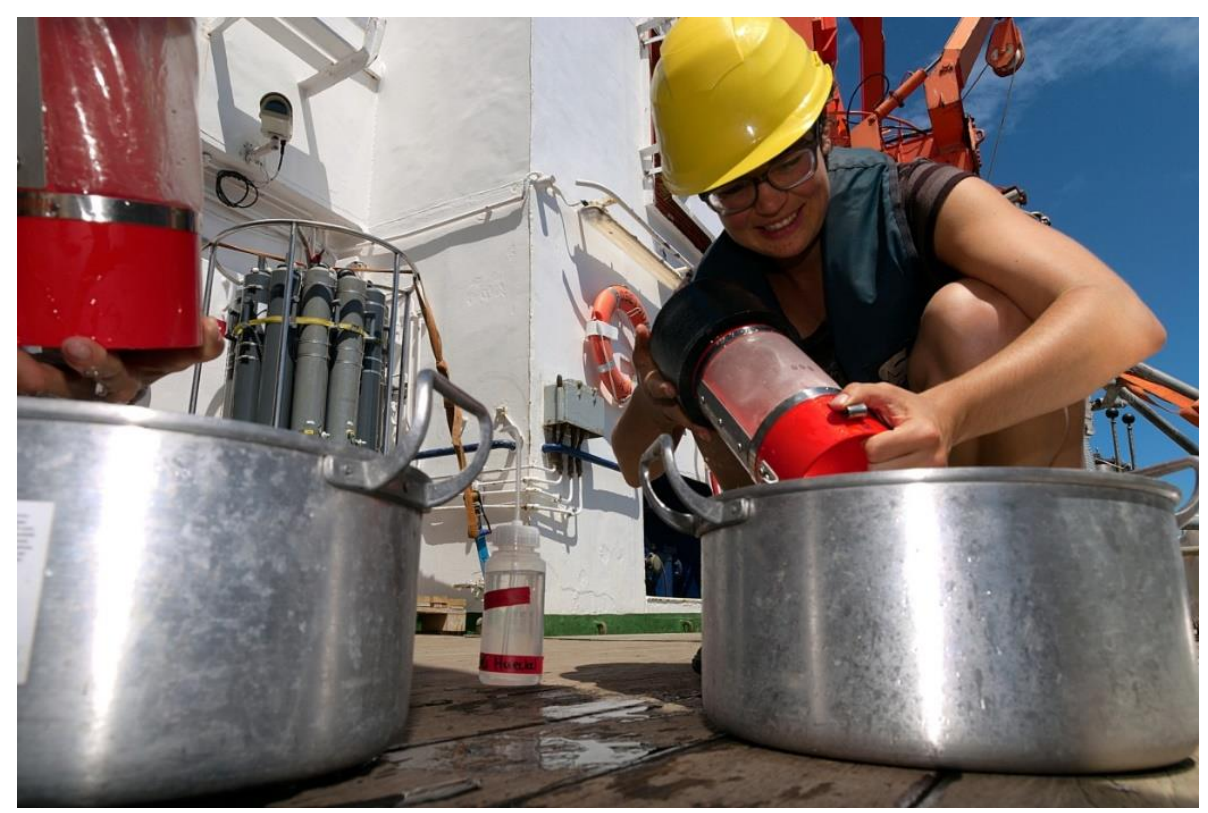

Figure 5.4-5 Rinsing the cod end of the bongo net with pre-filtered seawater. Plankton organisms and particles were first washed into an aluminium pot for visual inspection and then transferred to the glass storage containers Photo: Mark Lenz.

\section{Sample processing and analysis at GEOMAR}

The samples were transported to GEOMAR and will be prepared and analysed during 2020 .

For this, each sample will be rinsed again to remove the formalin and will then be visually inspected to a) pick microplastic particles and b) sort the collected plankton organisms into taxonomic groups (order or family level). 
After this, the biomass and the number of individuals in each groups will be assessed and then the organic material will be digested using enzymes of Fenton's reagent to release microplastic particles, which were potentially contained in the digestive tract or the gills of the collected organisms. After filtering the residual of the digestion process, the filter will be inspected for potentil microplastic particles under a microscope. All potential microplastic particles will finally be analysed using a Raman spectroscope or an FT/IR spectroscope to identify the polymer type. 
Table 5.4-2 Stations at which bongo net samples were collected during POS536.

\begin{tabular}{|c|c|c|c|c|c|c|c|c|}
\hline D-Ship & Date & $\begin{array}{l}\text { Time } \\
\text { (UTC) }\end{array}$ & Area & Latitude (start) & Latitude (end) & Longitude (start) & Longitude (end) & $\begin{array}{l}\text { Depth } \\
\text { (m) }\end{array}$ \\
\hline POS536_16-1 & 20.08 .2019 & $04: 34$ & $\mathrm{~B}$ & $33^{\circ} 16.46^{\prime} \mathrm{N}$ & $33^{\circ} 16.05^{\prime} \mathrm{N}$ & $034^{\circ} 34.72^{\prime} \mathrm{W}$ & $34^{\circ} 36.15^{\prime} \mathrm{W}$ & 10 \\
\hline POS536_17-1 & 20.08 .2019 & $05: 25$ & $\mathrm{~B}$ & $33^{\circ} 15.86^{\prime} \mathrm{N}$ & $33^{\circ} 16.64^{\prime} \mathrm{N}$ & $034^{\circ} 33.31^{\prime} \mathrm{W}$ & $34^{\circ} 35.99^{\prime} \mathrm{W}$ & 100 \\
\hline POS536_18-1 & 20.08 .2019 & $06: 36$ & $\mathrm{~B}$ & $33^{\circ} 15.74^{\prime} \mathrm{N}$ & $33^{\circ} 16.35^{\prime} \mathrm{N}$ & $034^{\circ} 33.86^{\prime} \mathrm{W}$ & $34^{\circ} 38.28^{\prime} \mathrm{W}$ & 300 \\
\hline POS536_33-1 & 23.08 .2019 & $02: 29$ & $\mathrm{C}$ & $33^{\circ} 09.05^{\prime} \mathrm{N}$ & $33^{\circ} 10.71^{\prime} \mathrm{N}$ & $39^{\circ} 59.88^{\prime} \mathrm{W}$ & $39^{\circ} 59.75^{\prime} \mathrm{W}$ & 17 \\
\hline POS536_34-1 & 23.08 .2019 & $03: 24$ & $\mathrm{C}$ & $33^{\circ} 09.16^{\prime} \mathrm{N}$ & $33^{\circ} 10.41^{\prime} \mathrm{N}$ & $39^{\circ} 59.96^{\prime} \mathrm{W}$ & $39^{\circ} 59.95^{\prime} \mathrm{W}$ & 174 \\
\hline POS536_35-1 & 23.08 .2019 & 04:29 & $\mathrm{C}$ & $33^{\circ} 08.97^{\prime} \mathrm{N}$ & $33^{\circ} 11.34^{\prime} \mathrm{N}$ & $39^{\circ} 59.91^{\prime} \mathrm{W}$ & $39^{\circ} 59.80^{\prime} \mathrm{W}$ & 336 \\
\hline POS536_48-1 & 25.08 .2019 & $23: 56$ & $\mathrm{D}$ & $34^{\circ} 37.687^{\prime} \mathrm{N}$ & $34^{\circ} 36.50^{\prime} \mathrm{N}$ & $039^{\circ} 27.872^{\prime} \mathrm{W}$ & $039^{\circ} 27.47 \mathrm{~W}$ & 10 \\
\hline POS536_49-1 & 25.08 .2019 & 01:04 & $\mathrm{D}$ & $34^{\circ} 38.561^{\prime} \mathrm{N}$ & $34^{\circ} 36.791^{\prime} \mathrm{N}$ & $39^{\circ} 27.808^{\prime} \mathrm{W}$ & $39^{\circ} 27.481^{\prime} \mathrm{W}$ & 100 \\
\hline POS536_50-1 & 25.08 .2019 & $02: 23$ & $\mathrm{D}$ & $34^{\circ} 38.506^{\prime} \mathrm{N}$ & $34^{\circ} 35.846^{\prime} \mathrm{N}$ & $039^{\circ} 27.788^{\prime} \mathrm{W}$ & $039^{\circ} 27.439^{\prime} \mathrm{W}$ & 300 \\
\hline POS536_58-1 & 25.08 .2019 & $22: 49$ & $E$ & $33^{\circ} 07.908^{\prime} \mathrm{N}$ & $33^{\circ} 07.588^{\prime} \mathrm{N}$ & $038^{\circ} 58.880^{\prime} \mathrm{W}$ & $038^{\circ} 57.349^{\prime} \mathrm{W}$ & 10 \\
\hline POS536_59-1 & 26.08 .2019 & $23: 47$ & $\mathrm{E}$ & $33^{\circ} 08.174^{\prime} \mathrm{N}$ & $33^{\circ} 07.655^{\prime} \mathrm{N}$ & $038^{\circ} 58.738^{\prime} \mathrm{W}$ & $038^{\circ} 57.134^{\prime} \mathrm{W}$ & 100 \\
\hline POS536_60-1 & 26.08 .2019 & $00: 59$ & $\mathrm{E}$ & $33^{\circ} 08.326^{\prime} \mathrm{N}$ & $33^{\circ} 07.529^{\prime} \mathrm{N}$ & $038^{\circ} 58.758^{\prime} \mathrm{W}$ & $038^{\circ} 56.426^{\prime} \mathrm{W}$ & 300 \\
\hline POS536_80-1 & 28.08 .2019 & $18: 20$ & $\mathrm{~F}$ & $34^{\circ} 20.145^{\prime} \mathrm{N}$ & $34^{\circ} 18.996^{\prime} \mathrm{N}$ & $038^{\circ} 30.235^{\prime} \mathrm{W}$ & $038^{\circ} 30.291^{\prime} \mathrm{W}$ & 10 \\
\hline POS536_81-1 & 28.08 .2019 & $19: 20$ & $\mathrm{~F}$ & $34^{\circ} 19.983^{\prime} \mathrm{N}$ & $34^{\circ} 18.399^{\prime} \mathrm{N}$ & $038^{\circ} 30.097^{\prime} \mathrm{W}$ & $038^{\circ} 30.013^{\prime} \mathrm{W}$ & 100 \\
\hline POS536_82-1 & 28.08 .2019 & $20: 31$ & $\mathrm{~F}$ & $34^{\circ} 20.002^{\prime} \mathrm{N}$ & $34^{\circ} 17.876^{\prime} \mathrm{N}$ & $038^{\circ} 30.055^{\prime} \mathrm{W}$ & $038^{\circ} 30.010^{\prime} \mathrm{W}$ & 300 \\
\hline POS536_93-1 & 30.08 .2019 & $02: 34$ & $\mathrm{G}$ & $33^{\circ} 08.826^{\prime} \mathrm{N}$ & $33^{\circ} 09.586^{\prime} \mathrm{N}$ & $037^{\circ} 59.724^{\prime} \mathrm{W}$ & $037^{\circ} 59.392^{\prime} \mathrm{W}$ & 10 \\
\hline POS536_94-1 & 30.08 .2019 & $03: 32$ & $\mathrm{G}$ & $33^{\circ} 09.277^{\prime} \mathrm{N}$ & $33^{\circ} 10.990^{\prime} \mathrm{N}$ & $037^{\circ} 59.872^{\prime} \mathrm{W}$ & $038^{\circ} 00.072^{\prime} \mathrm{W}$ & 100 \\
\hline POS536_95-1 & 30.08 .2019 & $04: 48$ & $\mathrm{G}$ & $33^{\circ} 09.086^{\prime} \mathrm{N}$ & $33^{\circ} 11.720^{\prime} \mathrm{N}$ & $037^{\circ} 59.989^{\prime} \mathrm{W}$ & $037^{\circ} 59.370^{\prime} \mathrm{W}$ & 300 \\
\hline POS536_100-1 & 30.08 .2019 & $21: 22$ & $\mathrm{H}$ & $34^{\circ} 39.407^{\prime} \mathrm{N}$ & $34^{\circ} 39.567^{\prime} \mathrm{N}$ & $037^{\circ} 31.874^{\prime} \mathrm{W}$ & $037^{\circ} 33.887^{\prime} \mathrm{W}$ & 10 \\
\hline POS536_101-1 & 30.08 .2019 & $22: 30$ & $\mathrm{H}$ & $34^{\circ} 39.374^{\prime} \mathrm{N}$ & $34^{\circ} 39.750^{\prime} \mathrm{N}$ & $037^{\circ} 31.084^{\prime} \mathrm{W}$ & $037^{\circ} 33.355^{\prime} \mathrm{W}$ & 100 \\
\hline POS536_102-1 & 30.08 .2019 & $23: 50$ & $\mathrm{H}$ & $34^{\circ} 39.286^{\prime} \mathrm{N}$ & $34^{\circ} 39.875^{\prime} \mathrm{N}$ & $037^{\circ} 31.009^{\prime} \mathrm{W}$ & $037^{\circ} 34.061^{\prime} \mathrm{W}$ & 300 \\
\hline POS536_118-1 & 01.09 .2019 & 13:06 & I & $33^{\circ} 08.428^{\prime} \mathrm{N}$ & $33^{\circ} 07.320^{\prime} \mathrm{N}$ & $036^{\circ} 59.402^{\prime} \mathrm{W}$ & $036^{\circ} 59.793^{\prime} \mathrm{W}$ & 10 \\
\hline POS536_119-1 & 01.09 .2019 & 14:10 & I & $33^{\circ} 08.999^{\prime} \mathrm{N}$ & $33^{\circ} 07.572^{\prime} \mathrm{N}$ & $037^{\circ} 00.064^{\prime} \mathrm{W}$ & $037^{\circ} 00.988^{\prime} \mathrm{W}$ & 100 \\
\hline POS536_120-1 & 01.09 .2019 & $15: 26$ & I & $33^{\circ} 09.037^{\prime} \mathrm{N}$ & $33^{\circ} 06.896^{\prime} \mathrm{N}$ & $037^{\circ} 00.030^{\prime} \mathrm{W}$ & $037^{\circ} 01.401^{\prime} \mathrm{W}$ & 300 \\
\hline POS536_127-1 & 02.09 .2019 & 09:40 & $\mathrm{J}$ & $34^{\circ} 14.595^{\prime} \mathrm{N}$ & $34^{\circ} 14.670^{\prime} \mathrm{N}$ & $037^{\circ} 01.106^{\prime} \mathrm{W}$ & $037^{\circ} 02.301^{\prime} \mathrm{W}$ & 10 \\
\hline POS536_128-1 & 02.09 .2019 & $10: 36$ & $\mathrm{~J}$ & $34^{\circ} 14.891^{\prime} \mathrm{N}$ & $34^{\circ} 15.370^{\prime} \mathrm{N}$ & $037^{\circ} 00.967^{\prime} \mathrm{W}$ & $037^{\circ} 02.940^{\prime} \mathrm{W}$ & 100 \\
\hline POS536_129-1 & 02.09 .2019 & $11: 49$ & $\mathrm{~J}$ & $34^{\circ} 14.961^{\prime} \mathrm{N}$ & $34^{\circ} 15.092^{\prime} \mathrm{N}$ & $037^{\circ} 00.654^{\prime} \mathrm{W}$ & $037^{\circ} 03.726^{\prime} \mathrm{W}$ & 300 \\
\hline POS536_135-1 & 04.09 .2019 & 08:02 & $\mathrm{K}$ & $33^{\circ} 09.898^{\prime} \mathrm{N}$ & $33^{\circ} 08.659^{\prime} \mathrm{N}$ & $033^{\circ} 52.552^{\prime} \mathrm{W}$ & $033^{\circ} 52.757^{\prime} \mathrm{W}$ & 10 \\
\hline POS536_136-1 & 04.09 .2019 & 08:59 & $\mathrm{K}$ & $33^{\circ} 09.958^{\prime} \mathrm{N}$ & $33^{\circ} 08.494^{\prime} \mathrm{N}$ & $033^{\circ} 52.583^{\prime} \mathrm{W}$ & $033^{\circ} 53.080^{\prime} \mathrm{W}$ & 100 \\
\hline POS536_137-1 & 04.09 .2019 & 10:09 & $\mathrm{K}$ & $33^{\circ} 09.951^{\prime} \mathrm{N}$ & $33^{\circ} 07.650^{\prime} \mathrm{N}$ & $033^{\circ} 52.391^{\prime} \mathrm{W}$ & $033^{\circ} 52.531^{\prime} \mathrm{W}$ & 300 \\
\hline
\end{tabular}




\subsection{Sediment sampling with multiple coring and box coring}

(Kristin Hamann, Sarah-Marie Kröger, Jenny Friedrich, Matthias Haeckel (PI))

\section{Research objectives and summary}

To assess the vertical distribution of micro-plastic from the water surface to the deep-sea, sediment samples were supposed to be collected at every station.

However, for our research area, no detailed bathymetric maps or data on sediment conditions are published. Due to the silty to sandy sediments that we encountered within the working area no multicorer (MUC) deployment was successful, but sediment samples were collected with the box corer (BC) at $5(\mathrm{C}, \mathrm{D}, \mathrm{E}, \mathrm{F}, \mathrm{H})$ out of 11 stations.

At station "I" the wire on the box corer broke and this prevented any further deployment of the gear.

\section{Description of the gear: Multicorer (MUC)}

The MUC is designed to recover undisturbed surface sediment sections along with the overlying bottom water. The MUC of GEOMAR is equipped with twelve $60 \mathrm{~cm}$ long plastic tubes (Figure 5.5-1). The MUC was used six times, but none of these deployments was successful (Table 5.51).

The MUC was lowered with a speed of $1 \mathrm{~m} / \mathrm{s}$ till about $50 \mathrm{~m}$ above the seafloor, where it was stopped for approximately 1 minute and then lowered with a speed of $0.5 \mathrm{~m} / \mathrm{s}$ until contact with the seafloor was monitored through the rope tension. The corer was left on the seafloor for about 1 minute, then pulled out with $0.1 \mathrm{~m} / \mathrm{s}$ to $0.3 \mathrm{~m} / \mathrm{s}$ and finally heaved with a speed of 1 $\mathrm{m} / \mathrm{s}$.

After some unsuccessful tries the MUC was only equipped with four liners to achieve a better weight to surface ratio. Still, no sediment was retrieved with the MUC. At station E we decided not to try further MUC deployments, but used two BCs instead. At station J another MUC deployment was tried after the wire of the BC broke. At station $\mathrm{K}$ a deployment was not possible as the water depth was below $3500 \mathrm{~m}$ and the ship's winch was only equipped for 3100 m. 


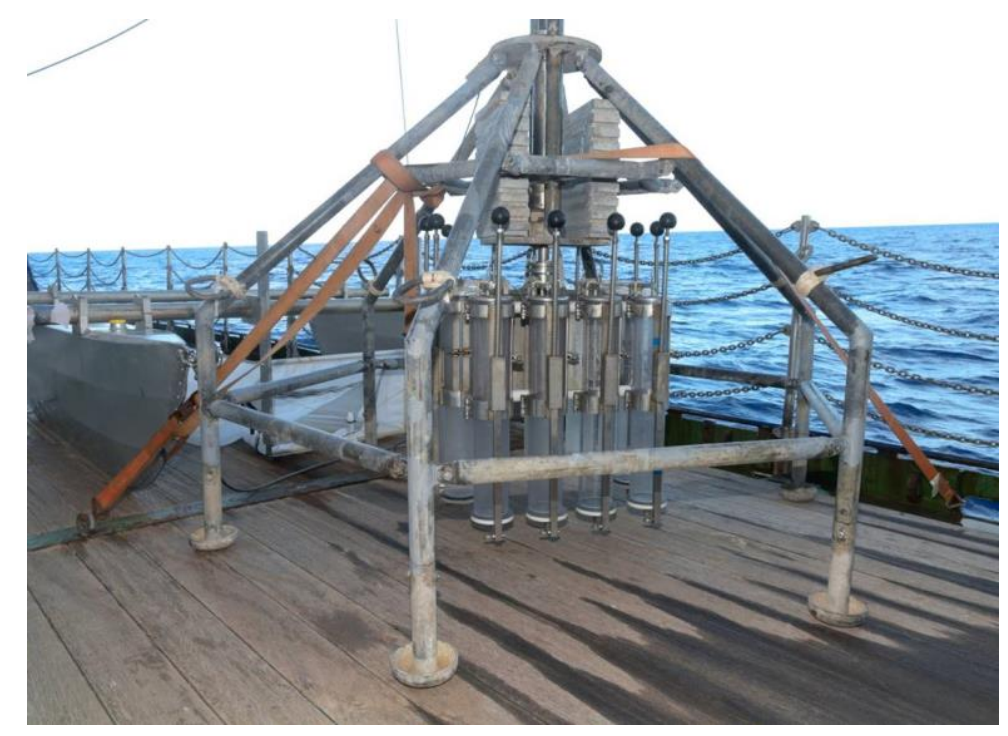

Figure 5.5-1 The multicorer on deck of RV Poseidon. Photo: Mark Lenz.

Table 5.5-1 Positions at which the multicorer (MUC) was deployed during POS536. Coordinates indicate the ship's GPS position.

\begin{tabular}{|c|c|c|c|c|c|c|c|}
\hline D-Ship & Date & $\begin{array}{l}\text { Time } \\
\text { (UTC) }\end{array}$ & $\begin{array}{c}\text { Number } \\
\text { liners }\end{array}$ & Area & Latitude & Longitude & $\begin{array}{c}\text { Water depth } \\
(\mathrm{m})\end{array}$ \\
\hline POS536_29-1 & 22.08 .2019 & $15: 50$ & $\begin{array}{l}1 \\
\text { (probably } \\
\text { disturbed) }\end{array}$ & $\mathrm{C}$ & $33^{\circ} 09.62^{\prime} \mathrm{N}$ & $40^{\circ} 00.705^{\prime} \mathrm{W}$ & 2956 \\
\hline POS536_40-1 & 23.08 .2019 & $12: 40$ & 0 & $\mathrm{C}$ & $33^{\circ} 08.849^{\prime} \mathrm{N}$ & $40^{\circ} 00.006^{\prime} \mathrm{W}$ & 2928 \\
\hline POS536_43-1 & 24.08 .2019 & $12: 46$ & 0 & $\mathrm{D}$ & $34^{\circ} 38.527^{\prime} \mathrm{N}$ & $39^{\circ} 27.732^{\prime} \mathrm{W}$ & 3027 \\
\hline POS536_44-1 & 24.08 .2019 & $14: 24$ & 0 & $\bar{D}$ & $34^{\circ} 38.496^{\prime} \mathrm{N}$ & $39^{\circ} 27.758^{\prime} \mathrm{W}$ & 3029 \\
\hline POS536_68-1 & 26.08 .2019 & $13: 23$ & 0 & $\mathrm{E}$ & $33^{\circ} 08.833^{\prime} \mathrm{N}$ & $038^{\circ} 59.378^{\prime} \mathrm{W}$ & 2154 \\
\hline POS536_125-1 & 02.09 .2019 & $08: 26$ & 0 & $\mathrm{~J}$ & $34^{\circ} 14.701^{\prime} \mathrm{N}$ & $037^{\circ} 00.961^{\prime} \mathrm{W}$ & 1473 \\
\hline POS536_126-1 & 02.09 .2019 & 09:10 & 0 & $\mathrm{~J}$ & $34^{\circ} 14.611^{\prime} \mathrm{N}$ & $037^{\circ} 01.100^{\prime} \mathrm{W}$ & 1417 \\
\hline
\end{tabular}

\section{Description of the gear: Box Corer (BC)}

The BC was used to collect the silty to sandy and quite stiff sediment in the working area (Figure 5.5-3). The corer consists of a $50 \mathrm{~cm} \times 50 \mathrm{~cm} \times 60 \mathrm{~cm}$ stainless steel box that sinks into the sediment. A friction release frees the spade arm when the weight of the corer is relieved from the wire. When the wire is reeled in to return the device to the ship, the initial action is to lever the spade down into the substrate until it closes off the bottom of the core. Subsequent take-up on the wire pulls the apparatus out of the bottom. At the top of the core box a cylindrical valve allows free passage to water entering at the mouth. The valve is opened during the descent and closed by a friction release mechanism triggered by the spade closure.

The BC was operated over winch 3 and lowered at a speed of $1 \mathrm{~m} / \mathrm{s}$ until it reaches a position at $100 \mathrm{~m}$ above the seafloor (Figure 5.5-2). After a stop of about one minute, the BC was lowered at a speed of $0.5 \mathrm{~m} / \mathrm{s}$ to $0.8 \mathrm{~m} / \mathrm{s}$ to the seafloor. Landing was visually assessed by a significant drop in rope tension. The winch was stopped 20 seconds after landing and the BC 
was pulled out after another 20 seconds. Pull out tension for successful box-coring is about 50 $\mathrm{kN}$.

In total, the $\mathrm{BC}$ was deployed 12 times, while 7 deployments were successful (Table 5.5-2). In area $\mathrm{A}$ and $\mathrm{B}$, the $\mathrm{BC}$ was not deployed due to the fact the water depths exceeded the available cable length. After the $12^{\text {th }}$ deployment, the wire was eroded and further deployments were considered too risky. For this reason, there were no BC deployments in area $\mathrm{J}$ and $\mathrm{K}$.

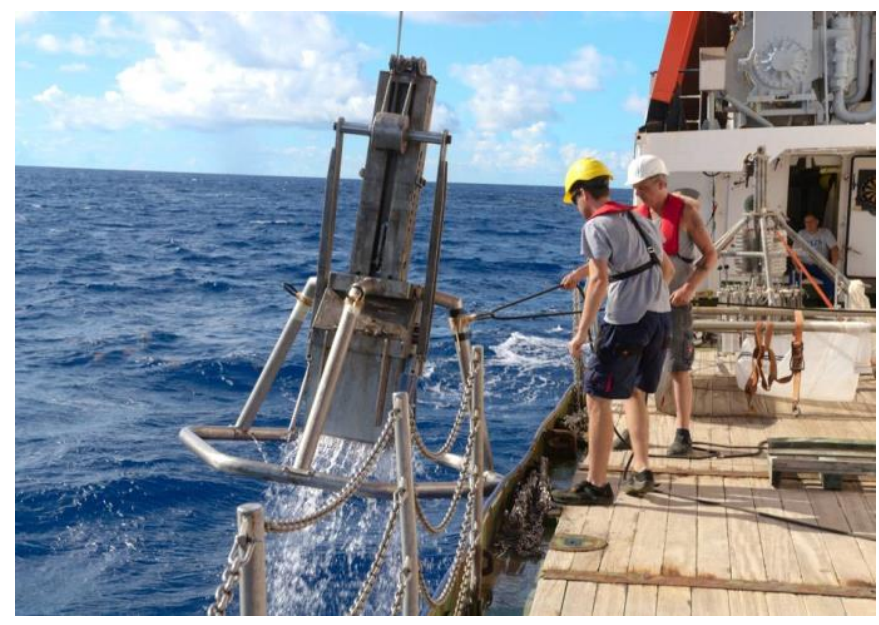

Figure 5.5-2 Recovery of the box corer after deployment to $3000 \mathrm{~m}$ water depth. Photo: Mark Lenz.

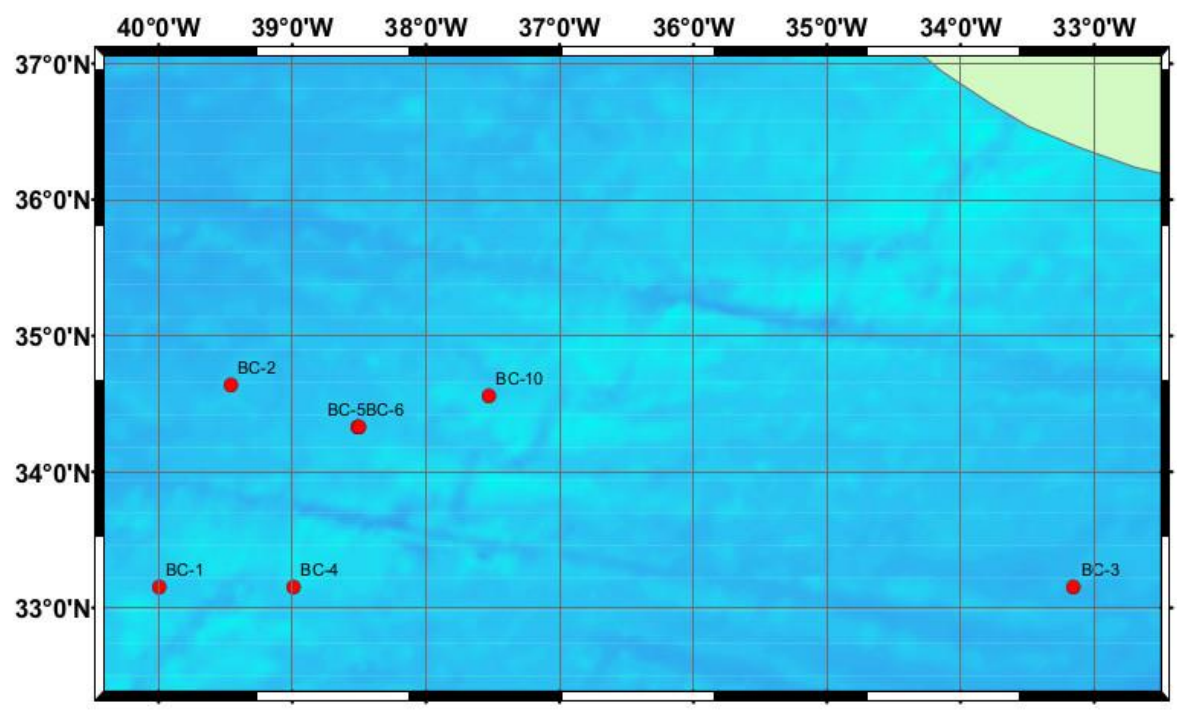

Figure 5.5-3 Stations at which boy corers were taken during POS 536.

\section{Sampling}

When the box corer was back on deck, the box was taken out of the gear for sampling. First, the geochemists put one to five MUC-liners into the sediment, leaving the rest of the sediment for the biologists (Figure 5.5-4). 
After the liners were pushed into the stiff sediment, the sediment water was soaked out and filtered before the front cover of the box was opened. Only in 2 out of the 7 successful deployments the BC held surface water.

Then the biologists removed two sediment layers: $0-3 \mathrm{~cm}$ and $3-6 \mathrm{~cm}$ and divided these in two grain size fractions by sieving.

The sediment was first washed through a $1000 \mu \mathrm{m}$ and then through a $500 \mu \mathrm{m}$ stainless steel sieve. Particles that remained on the sieves were stored in glass containers and preserved in a $4 \%$ formaldehyde/seawater solution. A first inspection under a dissecting microscope revealed that the sediment $>500 \mu \mathrm{m}$ contained mostly foraminifera shells, while the fraction $>1000 \mu \mathrm{m}$ revealed mostly shells of scaphopods, pteropods and a few small stones. No living organisms were found in the upper $6 \mathrm{~cm}$ of the sediment during sieving.

The liners were taken out and individually sliced into segments of $0-3 \mathrm{~cm}, 3-6 \mathrm{~cm}$ and 6 $-9 \mathrm{~cm}$, whereas the rest was discarded. The surface water, if any was available, was stored with the $0-3 \mathrm{~cm}$ sample of the respective liner.

In total, we collected 40 samples.

At the beginning only one liner was taken by the geochemists as it was planned to take more samples of the MUC-deployments. After later BC-deployments up to five liners were taken from one BC.

For geochemical analysis, the liner was sliced in steps of $1 \mathrm{~cm}$ until a depth of $10 \mathrm{~cm}$ was reached and then in steps of $2 \mathrm{~cm}$ from there to the lower end of the liner. The sediment was stored in whirlpacks and cooled.

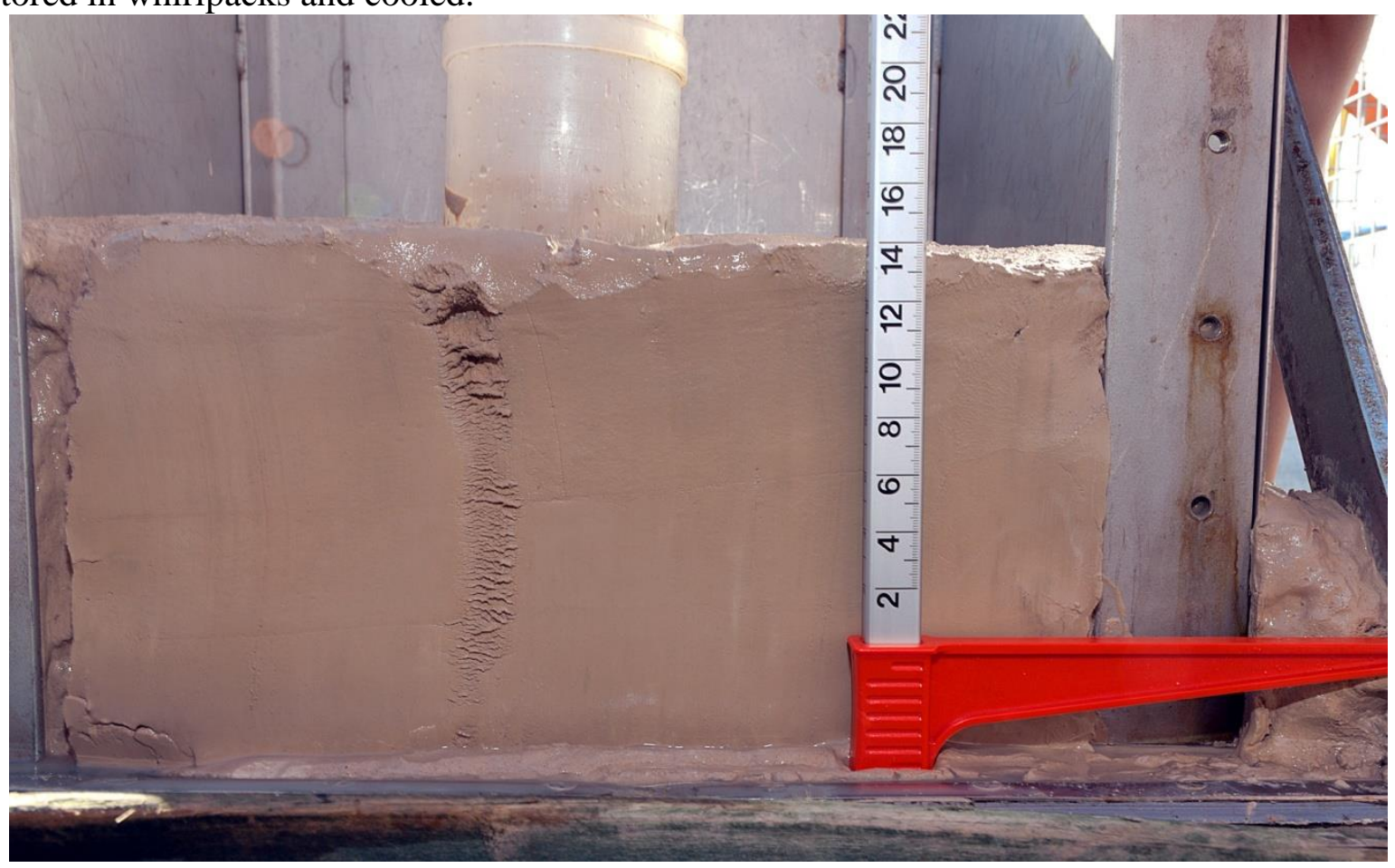

Figure 5.5-4 The sediment, which was collected by the box corer in the working area, was silty to sandy and very stiff. Photo: Mark Lenz. 


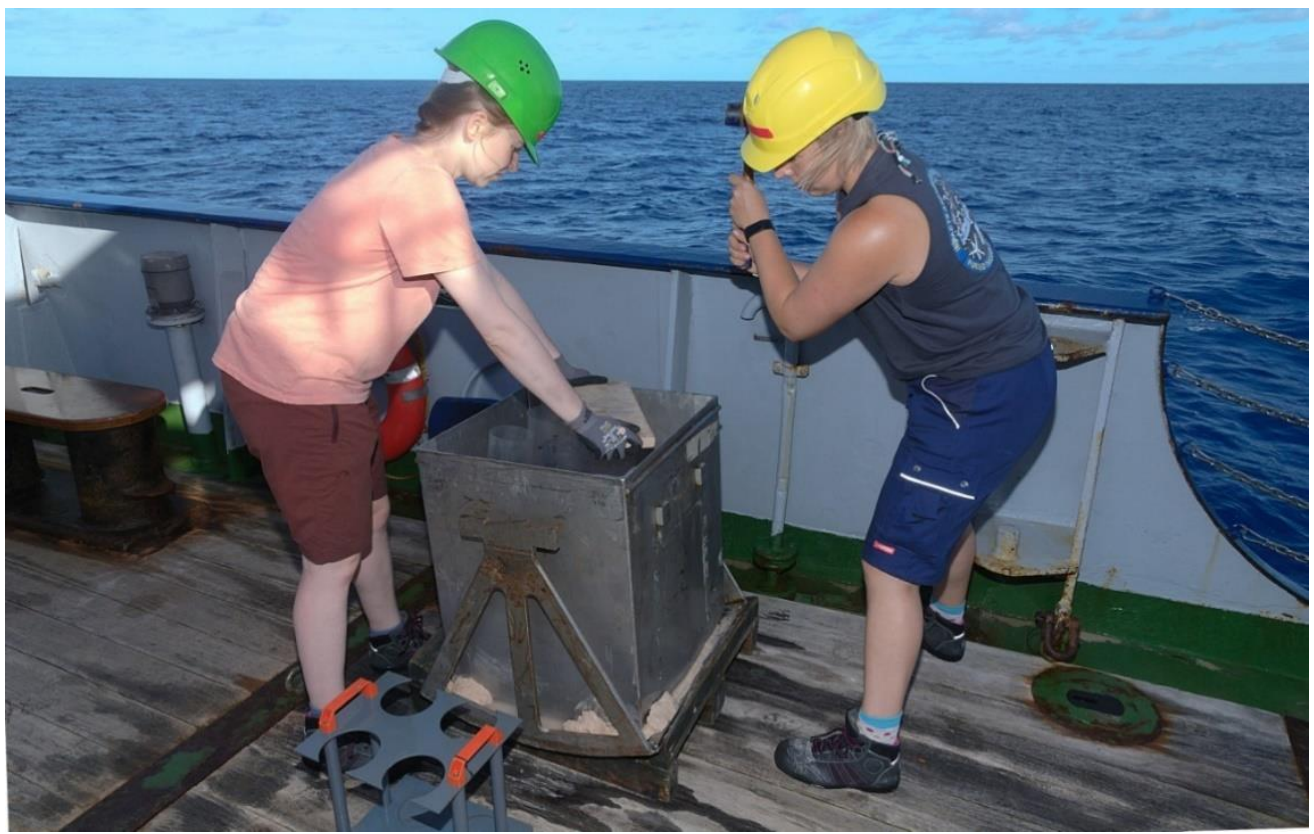

Figure 5.5-5 Taking liners from the box corer. Photo: Mark Lenz.

\section{Sample processing and analysis at GEOMAR}

The collected sediment samples will now be dried to avoid strong microbial degradation during storage. Samples will be processed sequentially for microplastic extraction by density separation and filtering as well as subsequent microscopic particle quantification and Raman spectroscopic polymer identification. This will likely take until the end of 2020.

Additional sediment subsamples are currently being processed for porosity measurements (by weight difference before and after freeze-drying), determination of solid phase POC, PON, TS and $\mathrm{CaCO}_{3}$ contents as well as porewater cation and anion analyses.

Table 5.5-2 Positions at which sediment samples were taken with the box corer (BC) during POS536. Coordinates indicate the ship's GPS position.

\begin{tabular}{|c|c|c|c|c|c|c|c|c|}
\hline D-Ship & Date & $\begin{array}{l}\text { Time } \\
\text { (UTC) }\end{array}$ & $\begin{array}{l}\text { Sampled } \\
\text { depth } \\
\text { (cm) }\end{array}$ & $\begin{array}{l}\text { Sample } \\
\text { number }\end{array}$ & Area & Latitude & Longitude & $\begin{array}{l}\text { Depth } \\
\text { (m) }\end{array}$ \\
\hline $28-1$ & 22.08 .2019 & $12: 58$ & $\begin{array}{l}0-3 \\
3-6 \\
6-9\end{array}$ & $\begin{array}{l}1 \\
2 \\
3\end{array}$ & $\mathrm{C}$ & $33^{\circ} 09.478^{\prime} \mathrm{N}$ & $40^{\circ} 00.251^{\prime} \mathrm{W}$ & 2931 \\
\hline $42-1$ & 24.08 .2019 & 09:04 & $\begin{array}{l}0-3 \\
3-6 \\
6-9\end{array}$ & $\begin{array}{l}4 \\
5 \\
6\end{array}$ & $\mathrm{D}$ & $34^{\circ} 38.59^{\prime} \mathrm{N}$ & $39^{\circ} 27.875^{\prime} \mathrm{W}$ & 3037 \\
\hline 66-1 & 26.08 .2019 & 09:16 & $\begin{array}{l}0-3 \\
3-6 \\
6-9 \\
0-3 \\
3-6 \\
6-9 \\
0-3 \\
3-6 \\
6-9 \\
14\end{array}$ & $\begin{array}{l}7 \\
8 \\
9 \\
10 \\
11 \\
12 \\
13 \\
14 \\
15 \\
12 \\
\text { whirlpacks }\end{array}$ & $\mathrm{E}$ & $33^{\circ} 09.081^{\prime} \mathrm{N}$ & $38^{\circ} 59.641^{\prime} \mathrm{N}$ & 2271 \\
\hline
\end{tabular}




\begin{tabular}{|c|c|c|c|c|c|c|c|c|}
\hline D-Ship & Date & $\begin{array}{l}\text { Time } \\
\text { (UTC) }\end{array}$ & $\begin{array}{l}\text { Sampled } \\
\text { depth } \\
\text { (cm) }\end{array}$ & $\begin{array}{l}\text { Sample } \\
\text { number }\end{array}$ & Area & Latitude & Longitude & $\begin{array}{l}\text { Depth } \\
\text { (m) }\end{array}$ \\
\hline $67-1$ & 26.08 .2019 & 10:31 & $\begin{array}{l}0-3 \\
3-6 \\
6-9\end{array}$ & $\begin{array}{l}16 \\
17 \\
18\end{array}$ & $\mathrm{E}$ & $33^{\circ} 09.081^{\prime} \mathrm{N}$ & $38^{\circ} 59.507^{\prime} \mathrm{W}$ & 2171 \\
\hline $72-1$ & 28.08 .2019 & 08:46 & $\begin{array}{l}0-3 \\
3-6 \\
6-9\end{array}$ & $\begin{array}{l}19 \\
20 \\
21\end{array}$ & $\bar{F}$ & $34^{\circ} 19.957^{\prime} \mathrm{N}$ & $38^{\circ} 30.378^{\prime} \mathrm{W}$ & 3043 \\
\hline $73-1$ & 28.08 .2019 & 10:47 & $\begin{array}{l}0-3 \\
3-6 \\
6-9 \\
0-3 \\
3-6 \\
6-9 \\
0-3 \\
3-6 \\
6-9 \\
0-3 \\
3-6 \\
6-9 \\
14\end{array}$ & $\begin{array}{l}22 \\
23 \\
24 \\
25 \\
26 \\
27 \\
28 \\
29 \\
30 \\
31 \\
32 \\
33 \\
12 \\
\text { whirlpacks }\end{array}$ & $\mathrm{F}$ & $34^{\circ} 19.568^{\prime} \mathrm{N}$ & $38^{\circ} 30.614^{\prime} \mathrm{W}$ & 3051 \\
\hline $84-1$ & 29.08 .2019 & 08:45 & & empty & G & $33^{\circ} 09.331^{\prime} \mathrm{N}$ & $37^{\circ} 59.851^{\prime} \mathrm{W}$ & 3064 \\
\hline $85-1$ & 29.08 .2019 & 10:13 & & empty & G & $33^{\circ} 09.102^{\prime} \mathrm{N}$ & $38^{\circ} 00.033^{\prime} \mathrm{W}$ & 3070 \\
\hline 104-1 & 31.08 .2019 & $08: 32$ & & empty & $\mathrm{H}$ & $34^{\circ} 39.029^{\prime} \mathrm{N}$ & $37^{\circ} 30.302^{\prime} \mathrm{W}$ & 3066 \\
\hline $105-1$ & 31.08 .2019 & $10: 48$ & $\begin{array}{l}\text { water sample } \\
0-3 \\
3-6 \\
6-9 \\
0-3 \\
3-6 \\
6-9 \\
16\end{array}$ & $\begin{array}{l}34 \\
35 \\
36 \\
37 \\
38 \\
39 \\
40 \\
13 \\
\text { whirlpacks }\end{array}$ & $\mathrm{H}$ & $34^{\circ} 33.329^{\prime} \mathrm{N}$ & $37^{\circ} 32.261^{\prime} \mathrm{W}$ & 2593 \\
\hline $116-1$ & 01.09 .2019 & 08:48 & & empty & I & $33^{\circ} 09.003^{\prime} \mathrm{N}$ & $36^{\circ} 59.976^{\prime} \mathrm{W}$ & 2980 \\
\hline $117-1$ & 01.09 .2019 & 10:20 & & empty & I & $33^{\circ} 09.046^{\prime} \mathrm{N}$ & $36^{\circ} 59.994^{\prime} \mathrm{W}$ & 2973 \\
\hline
\end{tabular}




\subsection{Thorium isotope tracer measurements and particle filtration with the Kiel-In-Situ- Pump system (KISP)}

(Aaron J. Beck, André Mutzberg, Eric Achterberg (PI))

This is a novel application of the naturally-occurring ${ }^{234} \mathrm{Th}$ tracer to quantify the vertical flux of microplastic particles under the North Atlantic garbage patch.

Less than approximately $10 \%$ of the plastic entering the ocean can currently be accounted for, likely due to fragmentation into small microplastics that are exported from the surface to the deep ocean. The radionuclide ${ }^{234} \mathrm{Th}$ has a half-life of 24.1 days, and is constantly produced by the decay of its parent ${ }^{238} \mathrm{U}$. While $U$ is highly soluble and mixes conservatively in oxygenated waters, ${ }^{234} \mathrm{Th}$ scavenges strongly to particle surfaces. Export of particulate ${ }^{234} \mathrm{Th}$ from the euphotic zone to the deep ocean produces a ${ }^{234} \mathrm{Th}$ deficit in the upper water column equal to the export flux. With information on the microplastic to ${ }^{234} \mathrm{Th}$ ratio $\left(\mathrm{MP} /{ }^{234} \mathrm{Th}\right)$ in sinking particles, the vertical fluxes of MPs can be quantified. These export fluxes will be used to improve the marine plastic mass balance, and determine if a deep ocean sink can account for the missing plastic mass.

During POS536, unfiltered seawater samples along a depth profile in the upper $500 \mathrm{~m}$ of the water column were collected with Niskin bottles mounted on a traditional CTD at 7 stations (Table 5.6-1; Fig. 5.6-1). Total ${ }^{234}$ Th activities, which include both dissolved and particulate phases, were determined on 41 samples, and up to 161 each were collected for particulate ${ }^{234} \mathrm{Th}$. Stations were chosen within the accumulation zone of the North Atlantic garbage patch (Cozar et al., 2014), where the highest MP abundances were expected. High vertical resolution sampling was performed within the upper $200 \mathrm{~m}$, where most of the biological activity occurs. Additional samples were collected as deep as $500 \mathrm{~m}$. Filtered $(0.45 \mu \mathrm{m}$ PES $)$ seawater $(10 \mathrm{ml})$ for ${ }^{238} \mathrm{U}$ concentrations was sampled from the same Niskin bottles as for ${ }^{234 \mathrm{Th}}$ (Figure 5.6-2). Additional samples for dissolved plastic leachates were collected downstream of the particulate ${ }^{234}$ Th filters by preconcentration on SPE-columns.

At 6 CTD stations, suspended and sinking particulates ( $>10 \mu \mathrm{m}$ on stainless steel mesh) were collected using the Kiel In Situ Pump system (KISP) (Figure 5.6-3, Table 5.6-2) that was deployed with the CTD cable. These KISP stations comprise a transect across the mid-ocean ridge (Fig. 5.6-4) and within the core of the North Atlantic garbage patch. 


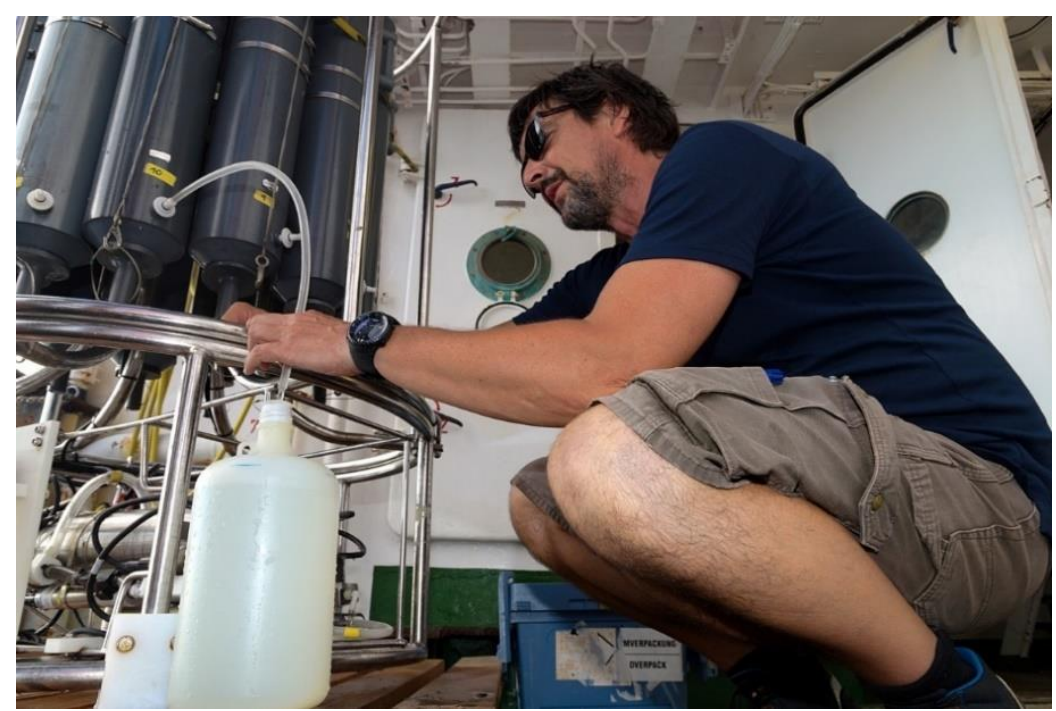

Figure 5.6-1 Samples of unfiltered seawater were collected along a depth profile in the upper $500 \mathrm{~m}$ of the water column by Niskin bottles that were mounted on the CTD. Photo: Mark Lenz.

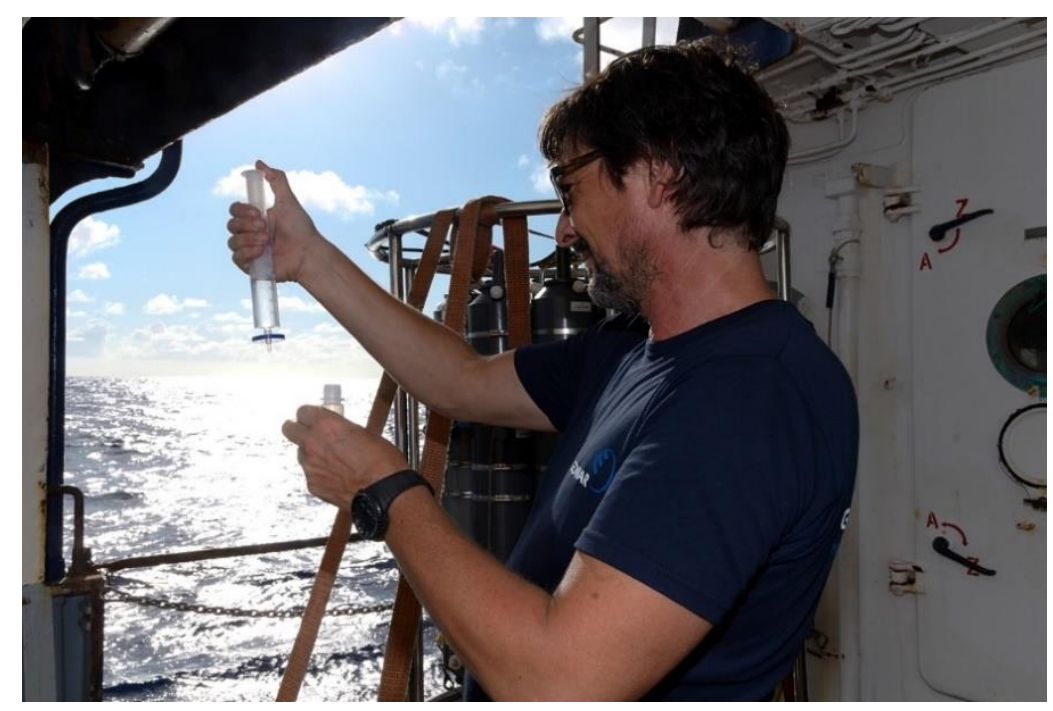

Figure 5.6-2 Water samples from the Niskin bottles were pre-filtered for the later follloed determination of ${ }^{238} \mathrm{U}$ concentrations. Photo: Mark Lenz. 


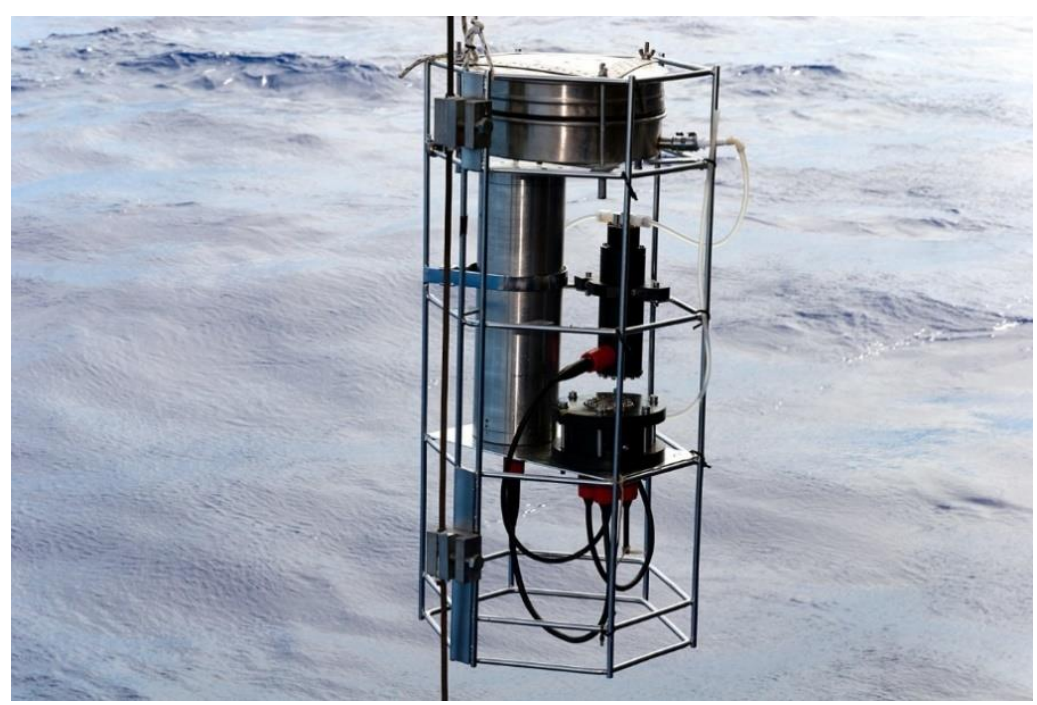

Figure 5.6-3 At six stations, particulates were collected from various water depth using the Kiel-In-Situ-Pump system. Photo: Mark Lenz.

Further samples for particulate ${ }^{234} \mathrm{Th}$ and microplastics $(>10 \mu \mathrm{m})$ were collected from the underway seawater system along four transects using a stand-alone filtration unit $(10 \mu \mathrm{m}$ stainless steel mesh) that was connected to the POSEIDON aquarium pump seawater tap (Table 5.6-3).

The chemical separation of thorium from seawater on board followed Van Der Loeff et al. (2006). Thorium was co-precipitated with $\mathrm{MnO}_{2}$ and filtered onto $25 \mathrm{~mm}$ silver filters $(3 \mu \mathrm{m}$ pore size). These precipitates were dried in an oven at $50^{\circ} \mathrm{C}$ for several hours before analysis. Filters of both total and particulate ${ }^{234}$ Th were mounted onto the Ris $\varnothing$ sample holders, and initial activities of ${ }^{234} \mathrm{Th}$ were counted on the Ris $\varnothing$ low-level beta GM multicounter.

Silver filters were used to collect particulate material to avoid contamination from plastic filter membranes, and to allow detection and identification of MP particles, as well as particulate organic carbon (POC). This method will provide the MP/Th ratio for quantifying MP export fluxes to the deep ocean. 


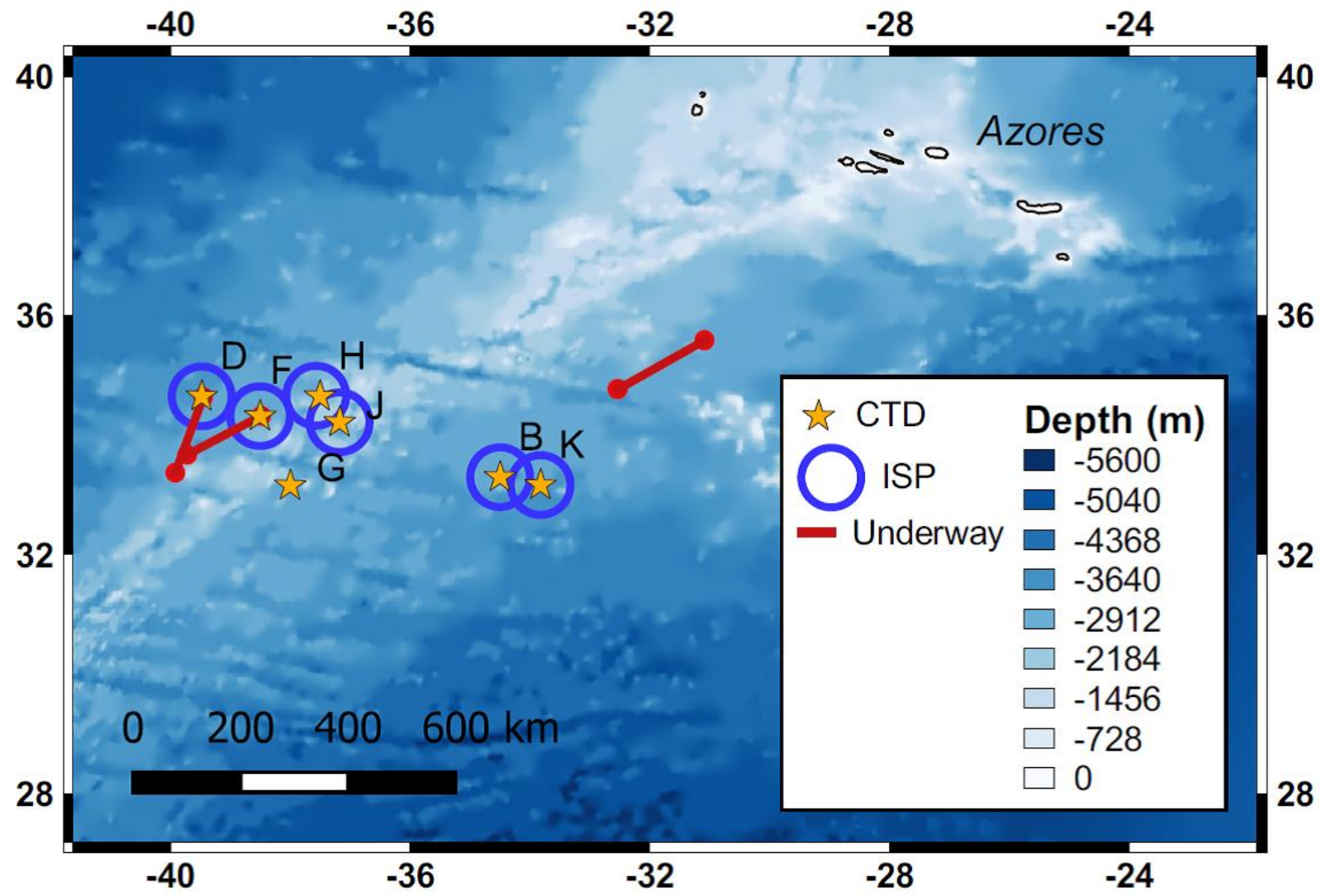

Figure 5.6-4 Stations at which either water samples were taken with the CTD or at which the In-Situ-Pump (ISP) system was deployed.

Table 5.6-1 List of stations at which seawater was collected with the CTD for total ${ }^{234 T h}$, Uranium, particulate 234Th, microplastics and plastic leachates during POS536.

\begin{tabular}{|c|c|c|c|c|c|c|}
\hline D-Ship & Date & $\begin{array}{l}\text { Time } \\
\text { (UTC) }\end{array}$ & Area & Latitude & Longitude & Depths (m) \\
\hline POS536_26-1 & 20.08 .2019 & $16: 39$ & B & $33^{\circ} 17.564^{`} \mathrm{~N}$ & $034^{\circ} 29.724^{\top} \mathrm{W}$ & $300,150,100,75,25$ \\
\hline POS536_41-1 & 24.08 .2019 & 01:59 & $\mathrm{D}$ & $34^{\circ} 38.676^{\prime} \mathrm{N}$ & $039^{\circ} 28.616^{\prime} \mathrm{W}$ & $300,150,100,75,50,25$ \\
\hline POS536_71-1 & 28.08 .2019 & $02: 10$ & $\mathrm{~F}$ & $34^{\circ} 18.769^{\prime} \mathrm{N}$ & $038^{\circ} 30.130^{\prime} \mathrm{W}$ & $300,150,100,75,50,25$ \\
\hline POS536_96-1 & 30.08 .2019 & 07:05 & G & $33^{\circ} 09.066^{\prime} \mathrm{N}$ & $037^{\circ} 59.975^{\prime} \mathrm{W}$ & $500,300,100,10$ \\
\hline POS536_103-1 & 31.08 .2019 & 02:06 & $\mathrm{H}$ & $34^{\circ} 39.369^{\prime} \mathrm{N}$ & $037^{\circ} 33.936^{\prime} \mathrm{W}$ & CTD failed \\
\hline POS536_109-1 & 31.08 .2019 & $15: 53$ & $\mathrm{H}$ & $34^{\circ} 38.755^{`} \mathrm{~N}$ & $037^{\circ} 30.174^{\prime} \mathrm{W}$ & $300,150,75,25$ \\
\hline POS536_133-1 & 02.09 .2019 & $16: 57$ & $\mathrm{~J}$ & $34^{\circ} 12.681^{\prime} \mathrm{N}$ & $037^{\circ} 10.490^{\prime} \mathrm{W}$ & $300,150,75,25$ \\
\hline POS536_144-1 & 04.09 .2019 & $16: 25$ & $\mathrm{~K}$ & $33^{\circ} 09.643^{`} \mathrm{~N}$ & $033^{\circ} 49.178^{\prime} \mathrm{W}$ & $300,150,75,50$ \\
\hline
\end{tabular}

Table 5.6-2 List of stations at which the in situ-pumps were used for sampling particulate ${ }^{234} \mathrm{Th}$ and microplastics during POS536.

\begin{tabular}{|c|c|c|c|c|c|c|}
\hline D-Ship & Date & $\begin{array}{l}\text { Time } \\
\text { (UTC) }\end{array}$ & Area & Latitude & Longitude & Depths (m) \\
\hline POS536_26-1 & 20.08 .2019 & $16: 39$ & B & $33^{\circ} 17.564^{`} \mathrm{~N}$ & $034^{\circ} 29.724^{\prime} \mathrm{W}$ & $300,150,75,50$ \\
\hline POS536_41-1 & 24.08 .2019 & 01:59 & $\mathrm{D}$ & $34^{\circ} 38.676^{\prime} \mathrm{N}$ & $039^{\circ} 28.616^{\prime} \mathrm{W}$ & $300,150,75,50$ \\
\hline POS536_71-1 & 28.08 .2019 & $02: 10$ & $\mathrm{~F}$ & $34^{\circ} 18.769^{\prime} \mathrm{N}$ & $038^{\circ} 30.130^{\prime} \mathrm{W}$ & $300,150,75,50$ \\
\hline POS536_103-1 & 31.08 .2019 & 02:06 & $\mathrm{H}$ & $34^{\circ} 39.369^{\prime} \mathrm{N}$ & $037^{\circ} 33.936^{\prime} \mathrm{W}$ & CTD failed \\
\hline POS536_133-1 & 02.09 .2019 & $16: 57$ & $\mathrm{~J}$ & $34^{\circ} 12.681^{\prime} \mathrm{N}$ & $037^{\circ} 10.490^{\prime} \mathrm{W}$ & $300,150,75,50$ \\
\hline POS536_144-1 & 04.09 .2019 & $16: 25$ & K & $33^{\circ} 09.643^{\prime} \mathrm{N}$ & $033^{\circ} 49.178^{\prime} \mathrm{W}$ & $150,75,50$ \\
\hline
\end{tabular}


Table 5.6-3 List of underway water samples for particulate ${ }^{234} \mathrm{Th}$ and microplastics.

\begin{tabular}{|c|c|c|c|c|}
\hline $\begin{array}{l}\text { Station number/sample } \\
\text { ID }\end{array}$ & Latitude start & Longitude start & Latitude stop & Longitude stop \\
\hline POS536_29-1-UWS-1 & $35^{\circ} 35,74^{`} \mathrm{~N}$ & $031^{\circ} 05,82^{\prime} \mathrm{W}$ & $34^{\circ} 46,62 \mathrm{~N}$ & $032^{\circ} 32,48^{`} \mathrm{~W}$ \\
\hline POS536_62-1-UWS-2 & $33^{\circ} 22,66^{\prime} \mathrm{N}$ & $039^{\circ} 55,48^{\prime} \mathrm{W}$ & $34^{\circ} 38,65^{\prime} \mathrm{N}$ & $039^{\circ} 27,84^{\prime} \mathrm{W}$ \\
\hline POS536_84-1-UWS-3 & $35^{\circ} 35,74^{\prime} \mathrm{N}$ & $031^{\circ} 05,82^{\prime} \mathrm{W}$ & $34^{\circ} 46,62^{\prime} \mathrm{N}$ & $032^{\circ} 32,48^{\prime} \mathrm{W}$ \\
\hline POS536_111-1-UWS-4 & $33^{\circ} 40,64^{\prime} \mathrm{N}$ & $039^{\circ} 43,69^{\top} \mathrm{W}$ & $34^{\circ} 19,99^{\prime} \mathrm{N}$ & $038^{\circ} 29,98^{`} \mathrm{~W}$ \\
\hline
\end{tabular}

\section{Sample processing and analysis at GEOMAR}

Filters of both total and particulate ${ }^{234}$ Th will be re-counted on the Ris $\varnothing$ low-level beta GM multicounter 5 months after sample collection, at which time ${ }^{234} \mathrm{Th}$ will have decayed to undetectable levels. The original beta activities will be corrected for any residual activity (i.e., from other nuclides with longer half-life). After the final counting, total ${ }^{234} \mathrm{Th}$ samples will be dismounted and dissolved in a mixture of $\mathrm{H}_{2} \mathrm{O}_{2}$ and $\mathrm{HNO}_{3}$, and analyzed by ICP-MS to determine chemistry yield (Pike et al., 2005). Particulate ${ }^{234}$ Th samples will be dismounted for MP analysis by FTIR or Raman spectroscopy, followed by POC analysis in order to determine the $\mathrm{MP} /{ }^{234} \mathrm{Th}$ and $\mathrm{POC} /{ }^{234} \mathrm{Th}$ ratios.

Seawater samples for uranium concentrations will be measured on the Element ICP-MS (Owens et al., 2011). We expect all chemical processing and analysis be completed within half a year from the end of POS536.

\subsection{Drifting Sediment Traps}

(L. Galgani, J. Roa, C. Schlundt, A. Engel (PI))

\section{Research objectives and summary}

Most of the particulate matter that is suspended in the water column is very fine, while larger particles rapidly sink to the benthic environment.

To characterize the ambient particle field in a given water body and to quantify the rates at which particles sink, in-situ particle collectors or sediment traps have been developed to distinguish between the permanently suspended and the sinking particulate matter.

Sediment traps collect small sediment particulates or larger accumulations called marine snow, which consist of organic matter, dead organisms, tiny shells, atmospheric dust and minerals. These sampling approaches are necessary to study important biogeochemical ocean processes and to assess seasonal variations in fluxes. They allow, inter alia, to describe the relationship between the rate of primary production and the downward flux of particulate organic matter and help to understand how fast nutrients and elements like carbon, nitrogen, phosphorus, calcium, and silicon move from the ocean surface to the deep sea. In the context of researching the fate of microplastics in open ocean environments, they allow to quantify the vertical transport of the anthropogenic particles and this will help us to understand how fast microplastics pass through the water column on their way to the deep sea benthos. 


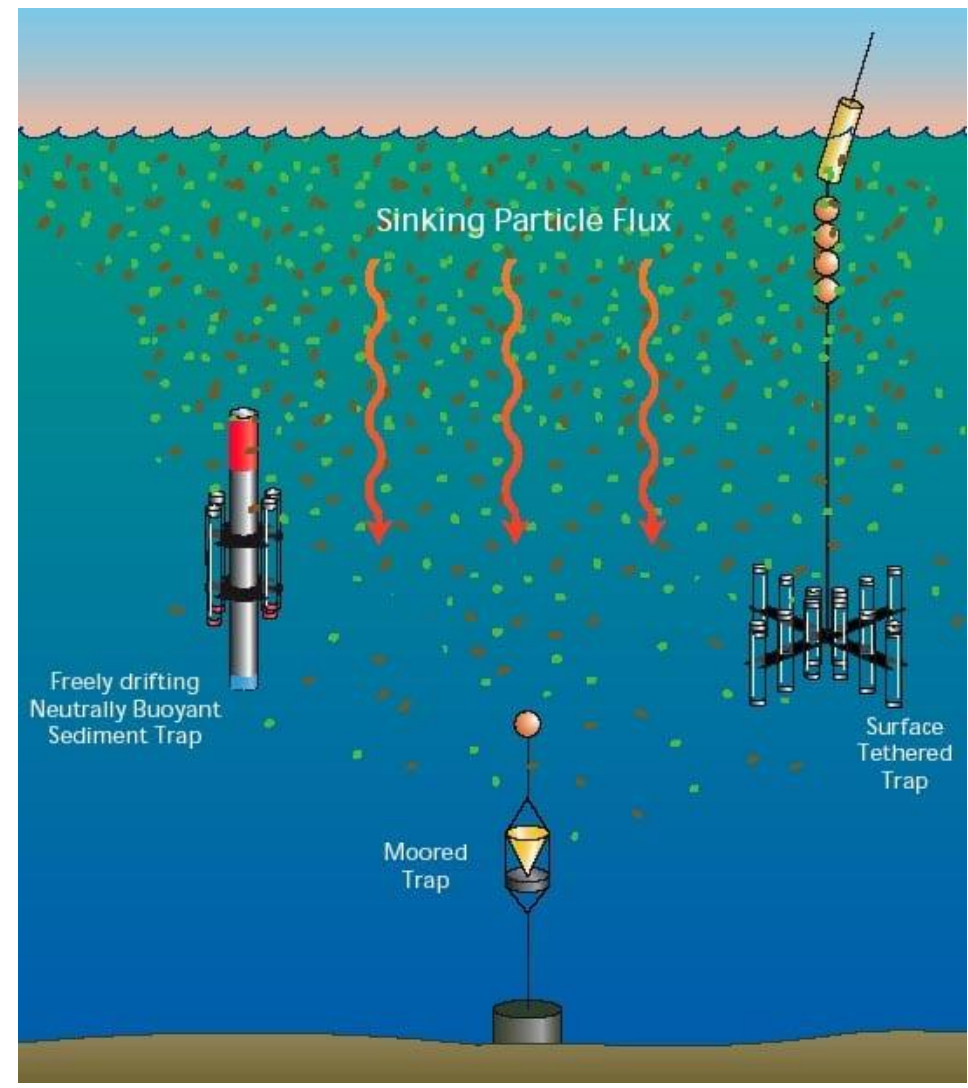

Figure 5.7-1 Different types of sediment traps (from WHOI).

\section{Description of the gear}

During POS536 cruise, we deployed a surface tethered drifting trap (Figure 5.7-1.) to collect sinking particulate matter and to capture plastic particles on their descent to the seafloor. The material collected was pre-screened $(500 \mu \mathrm{m})$ to remove zooplankton and visible plastic particles for later separate identification.

The system consisted of eight arrays mounted on a PVC cross frame to collect sinking material at $50 \mathrm{~m}, 100 \mathrm{~m}, 150 \mathrm{~m}, 200 \mathrm{~m}, 300 \mathrm{~m}, 400 \mathrm{~m}, 500 \mathrm{~m}$ and $600 \mathrm{~m}$. Each array contained twelve Particle Interceptor Traps (PITs) of which two served as blank controls for plastic contamination while handling the devices (Figure 5.7-2a). The PITs were $7 \mathrm{~cm}$ in diameter and $53 \mathrm{~cm}$ in height with an aspect ratio of 7.5 and a collection area of $0.0038 \mathrm{~m}^{2}$. The procedures for PIT preparation and sample recovery followed Engel et al. (2017). Each PIT was filled with $\sim 1.51$ of filtered seawater $(0.2 \mu \mathrm{m})$ that was collected from a depth of $300 \mathrm{~m}$ up to $24 \mathrm{hrs}$ before deployment. $500 \mathrm{ml}$ brine solution, which was prepared by adding $50 \mathrm{~g} \mathrm{NaCl}$ per 1 of $0.2 \mu \mathrm{m}$ filtered seawater were added through a tube to the bottom of each PIT. The difference in salinity allowed sinking particles to enter the traps, while the density gradient prevented that the particles escaped from the traps again.

Ten traps in each array were equipped with a top Acrylic glass baffle to restrain the entry of swimmers. Two blanks per array were closed with the red plastic lid and therefore did not 
collect any material but served as extra units that allowed to assess the potential contamination of the samples with plastics while handling and preparing the PITs.

During the cruise sediment traps were deployed twice (Table 5.7) and remained drifting in the water for 5 days, what was the longest possible time spam for the deployment, chosen to allow the collection of a maximum of sinking material.

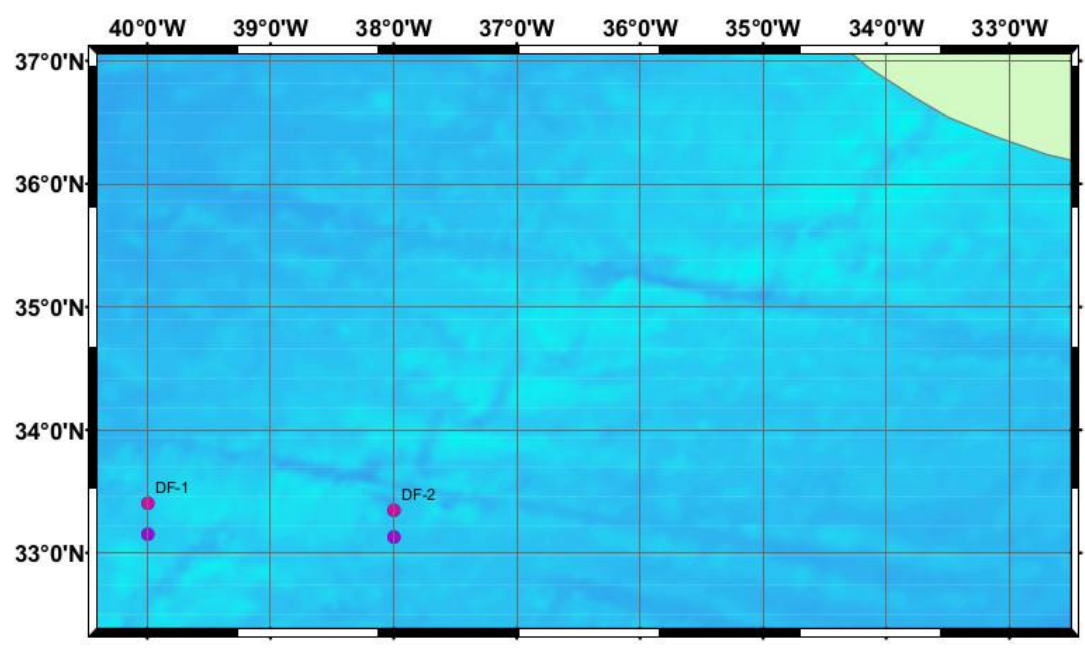

Figure 5.7-2 Positions at which sediment traps were deployed and retrieved during POS536.

Table 5.7 Positions at which sediment traps were deployed and retrieved during POS536.

\begin{tabular}{|c|c|c|c|c|c|}
\hline Dship & $\begin{array}{l}\text { Date of } \\
\text { deployment/reco } \\
\text { very }\end{array}$ & $\begin{array}{l}\text { Time in } \\
\text { water } \\
\text { (UTC) }\end{array}$ & $\begin{array}{l}\text { Latitude (in water) } \\
\text { Longitude (in } \\
\text { water) }\end{array}$ & $\begin{array}{l}\text { Time } \\
\text { on deck } \\
\text { (UTC) }\end{array}$ & $\begin{array}{l}\text { Latitude (on deck) } \\
\text { Longitude (on deck) }\end{array}$ \\
\hline POS536_27-1 & 22.08 .2019 & $9: 50$ & $\begin{array}{l}33^{\circ} 09.086^{\prime} \mathrm{N} 39^{\circ} \\
59.687^{\prime} \mathrm{W}\end{array}$ & & \\
\hline POS536_70-1 & 27.08 .2019 & & & $9: 25$ & $33^{\circ} 24.455^{\prime} \mathrm{N} 40^{\circ} 13.788^{\prime} \mathrm{W}$ \\
\hline POS536_86-1 & 29.08.2019 & 14:16 & 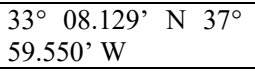 & & \\
\hline POS536_134-1 & 03.09 .2019 & & & $9: 26$ & $33^{\circ} 20.801^{\prime} \mathrm{N} 37^{\circ} 20.931^{\prime} \mathrm{W}$ \\
\hline
\end{tabular}



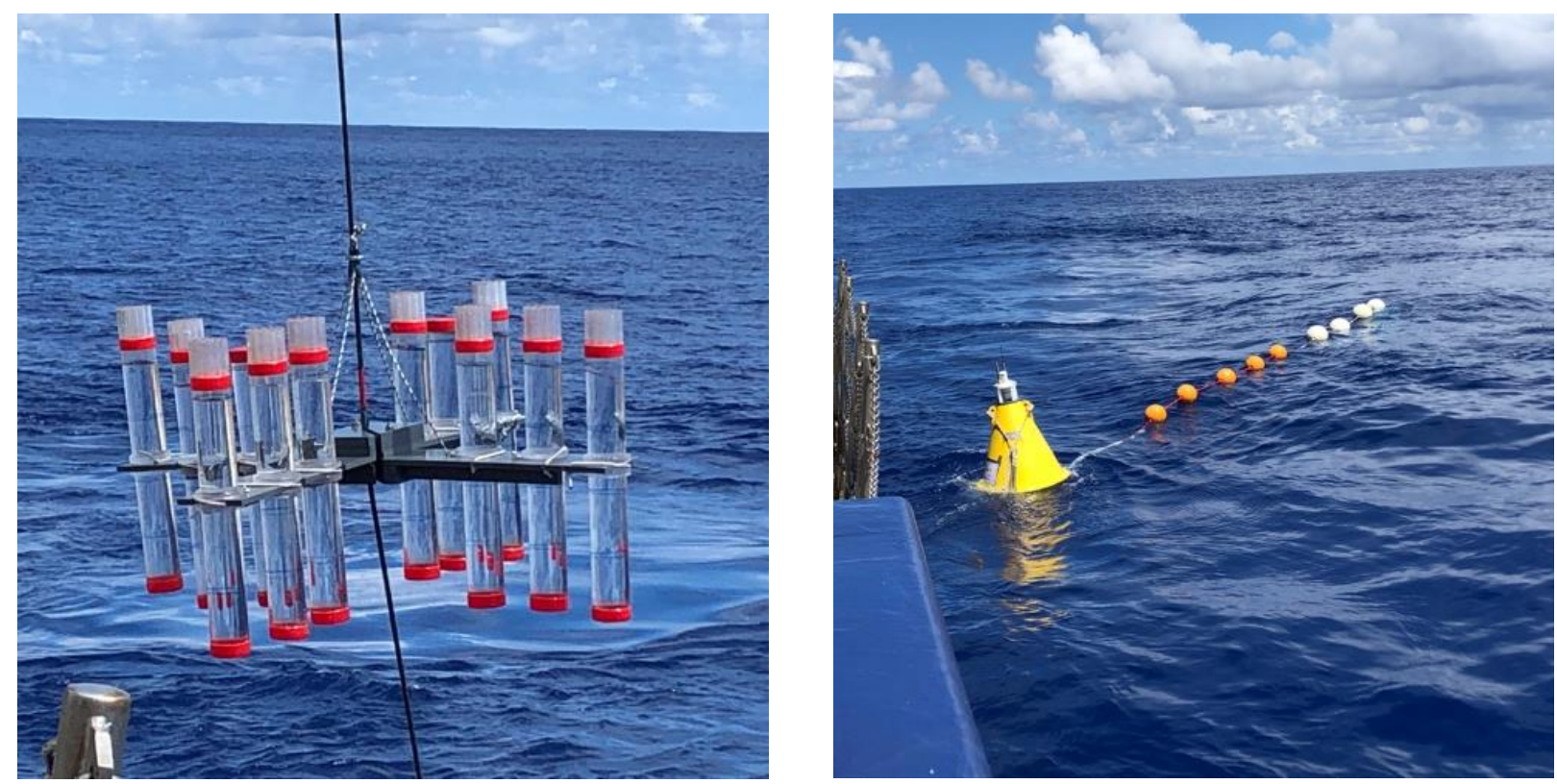

Figure 5.7-3 a) The $x$-shaped arrays in which each arm was holding three of 12 traps, i.e. 10 samples and two blanks. b) The floats and the buoy, which held the sediment traps in the water column, after deployment (Photo: Luisa Galgani).

The sediment trap system was previously tested during several expeditions in different oceanic areas (e.g. Engel et al. 2017). Each array is hooked onto a main rope, which has marks for the different water depths at which the traps are supposed to be deployed. Its lower end is attached to a weight of $70 \mathrm{~kg}$, while its upper is connected to five smaller (orange) and seven bigger floats (white) as well as a yellow buoy (Figure 5.7-2b). The yellow buoy carries two GPS beacons: an Argos and an Iridium system and a flashlight to allow for tracking and recovery of the traps after they drifted freely in the ocean.

\section{Sample processing and analyses}

Blanks and contamination controls

Almost all of the equipment that was associated with the deployment of the sediment traps was made of plastic. Therefore, each array (for every depth and every deployment) contained two traps that served as blank controls.

These traps, similar to those that were destined for sampling, were filled with filtered brine and filtered seawater, but they were kept sealed during deployment, so that neither particles nor seawater could enter the trap.

These served to assess any potential source of contamination that was caused by the set-up or the handling of the system.

The blanks were successively pooled and filtered through pre-combusted GF/F glass fiber filters for later RPy-GCMS. As an additional measure to prevent contamination, in particular 
with synthetic fibers, we worked in $100 \%$ cotton clothes while preparing the set-up and handling the samples.

After recovery, most of the filtered seawater in the traps was removed from them, while the brine, which contained the sampled material, from the ten traps and two blanks per depth was pooled to become one sample (Figure 5.7-3). On board of RV POSEIDON, all particulate matter contained in one sample was filtered to pre-weighted polycarbonate $0.4 \mu \mathrm{m}$ membranes.

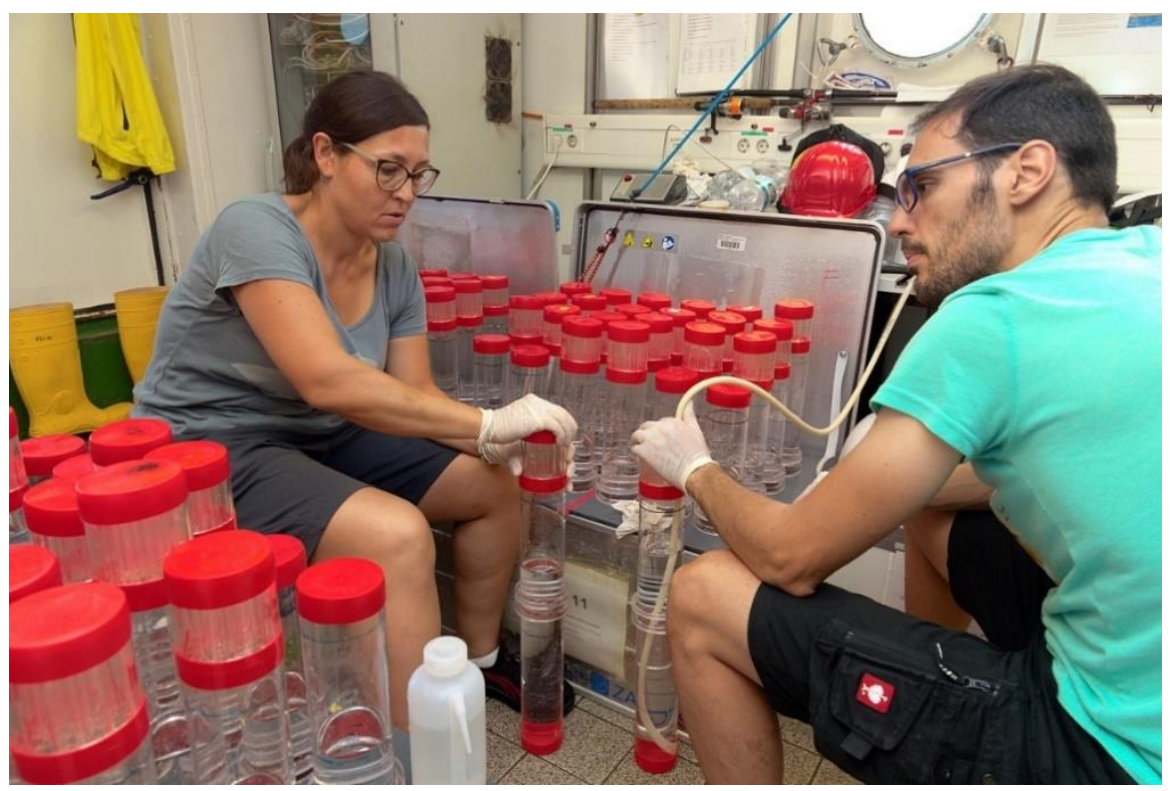

Figure 5.7-4 The seawater from the sediment traps was removed, while the brine fractions from 10 traps and the 2 blanks, which came from the same water depth, were pooled in one sample. Photo: Mark Lenz.

Material from PITs was collected on different filters on board and stored frozen or dry for later analysis at GEOMAR or partner laboratories. Particulate material collected on precombusted GF/F filters $(0.7 \mu \mathrm{m})$ will be analyzed for plastic hydrocarbons, particulate organic carbon (POC), total particulate carbon (TPC) and Chlorophyll a (Chl a). Plastic hydrocarbons will be determined after removal of all organic particles by acid hydrolysis, using Ramped Pyrolysis coupled with Gas Chromatography and Mass Spectrometry (RPy-GC-MS) in collaboration with Z. Liu, University of Texas, US. (POC) will be analyzed by high temperature combustion and elemental $\mathrm{CN}$ analysis after exposure to fuming hydrochloric acid overnight to remove carbonates. TPC will be determined by high-temperature combustion. The PIC (Particulate Inorganic Carbon) will be calculated by subtracting the POC from TPC (TPC = PIC + POC).

Chl a will be quantified by fluorometry after acetone extraction.

For determination of marine gels (Transparent Exopolymer Particles, TEP, and Coomassie Stainable Particles, CSP) different aliquots of trap material were filtered onto $0.4 \mu \mathrm{m}$ polycarbonate membranes (Nuclepore). The number and size of marine gel particles in the descending flux to the seafloor will be analyzed by brightfield microscopy and quantified by image analysis. 
To examine microbial colonization of particles, samples for CLSM - Confocal Laser Scanning Electron Microscope were filtered onto black $0.2 \mu \mathrm{m}$ polycarbonate membranes. Filters will be stained with fluorescent probes and analyzed by CLSM to individuate biological material attached to plastic particles $(<500 \mu \mathrm{m})$.

In addition individual particles $>500 \mu \mathrm{m}$ that appeared to contain plastic were isolated from $300 \mathrm{~m}, 200 \mathrm{~m}$ and $150 \mathrm{~m}$ respectively. The ones collected in traps at $200 \mathrm{~m}$ and $150 \mathrm{~m}$ depths have a spherical shape. From the second deployment, only an irregular fragment was found in the traps deployed at $300 \mathrm{~m}$. These particles have been fixed in formaldehyde and subsequently washed and preserved in Eppendorf tubes in a mix of 50:50 Ethanol:Milli-Q water for later analysis of the biofilm community composition by CLSM.

Total mass of sinking particles collected in the PITs will be determined from aliquots of trap material filtered onto pre-weighed $0.4 \mu \mathrm{m}$ polycarbonate filters using a microbalance.

\subsection{CTD and water sampler rosette}

(André Mutzberg, Thea Hamm)

A CTD with a water sampler rosette was used to collect oceanographic data at the stations B K (Figure 5.8-1, Table 5.8). The system was operated with winch 2 from the port side of RV Poseidon and water depths to which the device was deployed were controlled by pressure and altimeter readings.

The CTD was equipped with 6 pressure sensors: 2 temperature sensors, 2 oxygen sensors and 2 conductivity sensors. Furthermore, $\mathrm{pH}$ (SBE27) and altimeter sensors were attached. The SBE underwater unit and Niskin bottle carousel motor were powered via the winch's coaxialcable by using the modem/power unit from SST (Linke et al., 2015).

CTD data recording and triggering of the Niskin bottles were controlled with the SEASAVE software (version 7.21) on an external laptop. CTD data were recorded with $24 \mathrm{~Hz}$. GPS position data were logged parallel to the CTD.

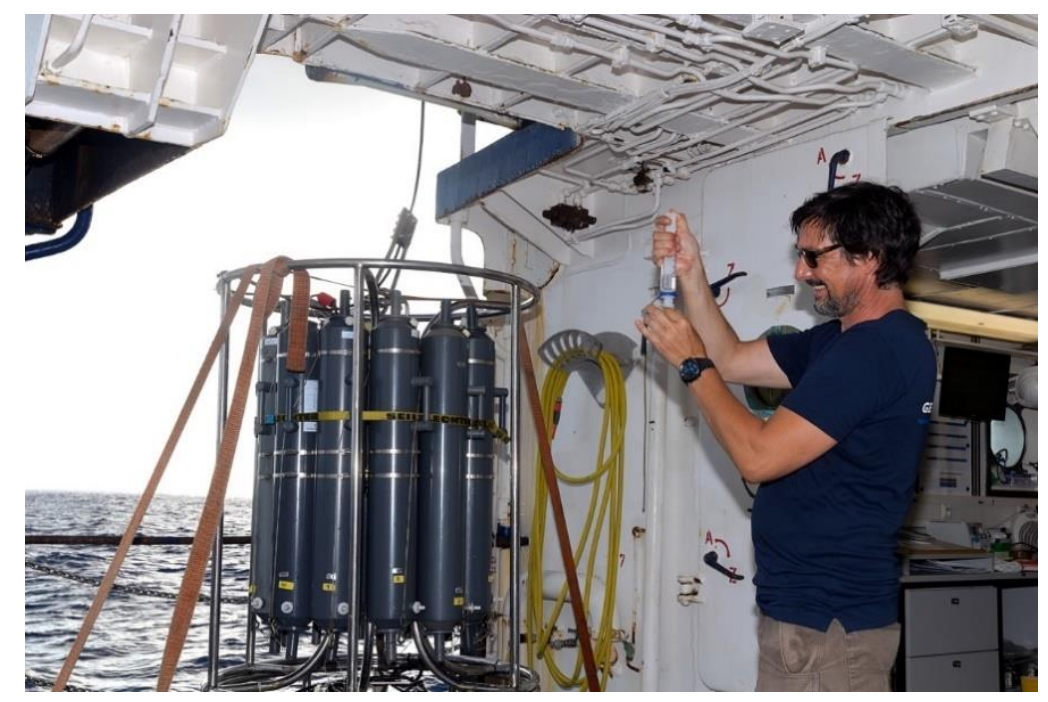

Figure 5.8-1 The CTD with the water sampler rosette. Photo: Mark Lenz 
Hydro-casts and hydrographic data from towed CTDs were processed by using the SBE software SBE7.22.1. Usually data files of 1 minute bins and 1 meter bins were created from raw data files and exported to ASCII.

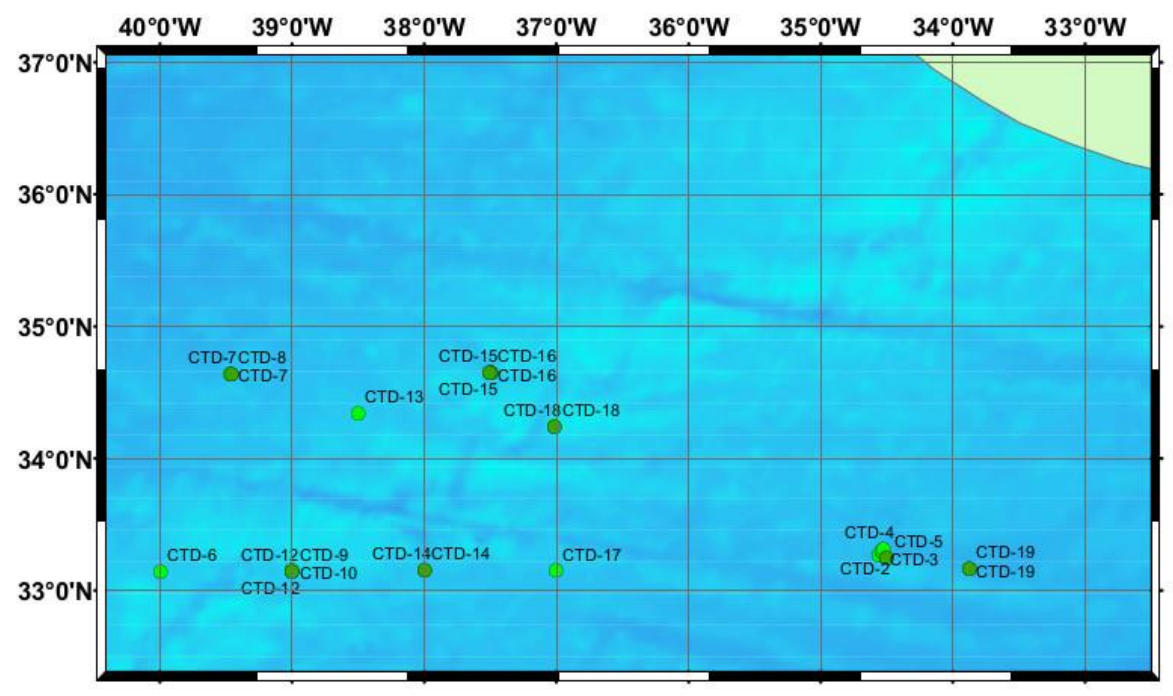

Figure 5.8-2 Stations at which CTD profiles were taken during POS536. 
Table 5.8 Stations at which the CTD system was deployed during POS536.

\begin{tabular}{|c|c|c|c|c|c|}
\hline D-Ship & Date & \begin{tabular}{|l} 
Time/max.depth \\
(UTC)
\end{tabular} & Area & $\begin{array}{l}\text { Latitude/max. } \\
\text { depth }\end{array}$ & $\begin{array}{c}\text { Longitude/max } \\
\text { depth }\end{array}$ \\
\hline POS536_22-1 & 20.08 .2019 & $12: 58$ & $\mathrm{~B}$ & $33^{\circ} 16.63^{\prime} \mathrm{N}$ & $034^{\circ} 32.97^{\prime} \mathrm{W}$ \\
\hline POS536_23-1 & 20.08 .2019 & $14: 05$ & $\mathrm{~B}$ & $33^{\circ} 17.74^{\prime} \mathrm{N}$ & $34^{\circ} 32.22^{\prime} \mathrm{W}$ \\
\hline POS536_24-1 & 20.08 .2019 & $14: 45$ & B & $33^{\circ} 18.39^{\prime} \mathrm{N}$ & $34^{\circ} 31.86^{\prime} \mathrm{W}$ \\
\hline POS536_25-1 & 20.08 .2019 & $15: 16$ & $\mathrm{~B}$ & $33^{\circ} 18.80^{\prime} \mathrm{N}$ & $34^{\circ} 31.49^{\prime} \mathrm{W}$ \\
\hline POS536_26-1 & 20.08 .2019 & $16: 39$ & $\mathrm{~B}$ & $33^{\circ} 15.256^{\prime} \mathrm{N}$ & $34^{\circ} 29.895^{\prime} \mathrm{W}$ \\
\hline POS536_39-1 & 23.08 .2019 & $10: 25$ & $\mathrm{C}$ & $33^{\circ} 08.87^{\prime} \mathrm{N}$ & $39^{\circ} 59.97^{\prime} \mathrm{W}$ \\
\hline POS536_41-1 & 24.08 .2019 & $01: 59$ & $\mathrm{D}$ & $34^{\circ} 38.630^{\prime} \mathrm{N}$ & $39^{\circ} 27.826^{\prime} \mathrm{W}$ \\
\hline POS536_54-1 & 25.08 .2019 & $07: 43$ & $\mathrm{D}$ & $34^{\circ} 38.59^{\prime} \mathrm{N}$ & $39^{\circ} 27.97^{\prime} \mathrm{W}$ \\
\hline POS536_64-1 & 26.08 .2019 & 05:39 & $\mathrm{E}$ & $33^{\circ} 08.90^{\prime} \mathrm{N}$ & $38^{\circ} 59.813^{\prime} \mathrm{W}$ \\
\hline POS536_65-1 & 26.08 .2019 & $06: 37$ & $\mathrm{E}$ & $33^{\circ} 09.128^{\prime} \mathrm{N}$ & $38^{\circ} 59.905^{\prime} \mathrm{W}$ \\
\hline POS536_69-1 & 26.08 .2019 & $14: 22$ & $E$ & $33^{\circ} 08.981^{\prime} \mathrm{N}$ & $39^{\circ} 00.020^{\prime} \mathrm{W}$ \\
\hline POS536_71-1 & 28.08 .2019 & 02:10 & $\mathrm{F}$ & $34^{\circ} 19.947^{\prime} \mathrm{N}$ & $38^{\circ} 30.012^{\prime} \mathrm{W}$ \\
\hline POS536_83-1 & 28.08 .2019 & $22: 29$ & $\mathrm{~F}$ & $34^{\circ} 19.933^{\prime} \mathrm{N}$ & $38^{\circ} 30.331^{\prime} \mathrm{W}$ \\
\hline POS536_96-1 & 30.08 .2019 & 07:05 & $\mathrm{G}$ & $33^{\circ} 09.122^{\prime} \mathrm{N}$ & $37^{\circ} 59.967^{\prime} \mathrm{W}$ \\
\hline POS536_103-1 & 31.08 .2019 & 02:06 & $\mathrm{H}$ & $34^{\circ} 39.097^{\prime} \mathrm{N}$ & $37^{\circ} 30.029^{\prime} \mathrm{W}$ \\
\hline POS536_109-1 & 31.08 .2019 & $15: 53$ & $\mathrm{H}$ & $34^{\circ} 38.912^{\prime} \mathrm{N}$ & $37^{\circ} 30.121^{\prime} \mathrm{W}$ \\
\hline POS536_121-1 & 01.09 .2019 & $17: 33$ & $\mathrm{I}$ & $33^{\circ} 08.991^{\prime} \mathrm{N}$ & $37^{\circ} 00.182^{\prime} \mathrm{W}$ \\
\hline POS536_133-1 & 02.09.2019 & $16: 57$ & $\mathrm{~J}$ & $34^{\circ} 14.572^{\prime} \mathrm{N}$ & $37^{\circ} 01.210^{\prime} \mathrm{W}$ \\
\hline POS536_144-1 & 04.09 .2019 & $16: 25$ & $\mathrm{~K}$ & $33^{\circ} 09.916^{\prime} \mathrm{N}$ & $33^{\circ} 52.464^{\prime} \mathrm{W}$ \\
\hline
\end{tabular}

\section{9 pCO2 and microplastic sampling in the mixed layer}

(Sarah-Marie Kröger, Kristin Hamann, Toste Tanhua (PI))

\section{Description of the gear}

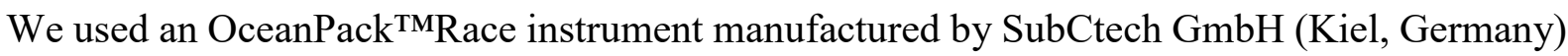
for recording $\mathrm{pCO} 2$ in the surface mixed layer during the cruise. The instrument was installed in the main laboratory of POSEIDON and was connected to the ship's seawater inlet while the vessel was in Bremerhaven prior to the cruise. During the cruise, the system was started as soon as the the vessel had left the Portuguese EEZ. The instrument operated continuously for 19 days, with a short interruption on August $30^{\text {th }}$ as there was a technical problem with the pump that supplied the seawater. On September $6^{\text {th }}$ a faulty gas pump of the LiCor detector stopped the measurements. The pump could not be repaired on board and, hence, the operation was suspended at this point.

The pCO2 data were calibrated twice a day with zero air (i.e. air with no $\mathrm{CO}_{2}$ in it) from a soda lime scrubber, and twice daily from a span gas calibrated by the ICOS laboratory. The instrumentation also measured temperature and salinity. The data will be processed and submitted to the SOCAT data base (www.socat.info).

The microplastics sampling equipment of the OceanPack ${ }^{\text {TM}}$ Race consisted of sets of three custom-built stainless-steel filters with an opening diameter of $44 \mathrm{~mm}$ and mesh-size of 28, 100 and $500 \mu \mathrm{m}$. The seawater that was pumped to the $\mathrm{pCO} 2$ system of the OceanPack was diverted to the microplastics filtration system before reaching the pCO2 system. The filters were exchanged daily and in total 18 filter sets were collected during POS536. The filters were stored in aluminum bags for later analysis. The $\mathrm{pCO} 2$ system was connected to the microplastics filtration system and logged the flow of water through the filters so that the total amount of 
water that passed a filter can be calculated. The samples are in a laboratory in Kiel and will be processed as soon as machine time for the spectroscopic analysis is available.

Table 5.9 Stations at which filters from the OceanPack ${ }^{\mathrm{TM}}$ Race were collected during POS536.

\begin{tabular}{|c|c|c|c|c|c|c|}
\hline $\begin{array}{l}\text { Station (group } \\
\text { protocol }\end{array}$ & DShip & Area & Date & Time & Latitude & Longitude \\
\hline $\begin{array}{l}\text { POS536_19- } \\
\text { 1_OP_1 }\end{array}$ & NA & $\mathrm{A}$ & 19.08 .2019 & $18: 18$ & $\begin{array}{l}35^{\circ} 35.02^{\prime} \mathrm{N} \\
\text { (erroneous) }\end{array}$ & $031^{\circ} 04.97^{\prime} \mathrm{W}$ \\
\hline $\begin{array}{l}\text { POS536_34- } \\
\text { 1_CTD-5 }\end{array}$ & NA & B & 19.08 .2019 & $18: 05$ & $33^{\circ} 16,13^{`} \mathrm{~N}$ & $34^{\circ} 29,54^{`} \mathrm{~W}$ \\
\hline $\begin{array}{l}\text { POS536_41- } \\
\text { 1_OP-2 }\end{array}$ & NA & B-C & 21.08 .2019 & $18: 15$ & $32^{\circ} 59.21^{\prime} \mathrm{N}$ & $37^{\circ} 52.85^{\prime} \mathrm{W}$ \\
\hline $\begin{array}{l}\text { POS536_45- } \\
\text { 1_OP-3 }\end{array}$ & NA & $\mathrm{C}$ & 22.08 .2019 & $18: 15$ & $33^{\circ} 09.81^{\prime} \mathrm{N}$ & $40^{\circ} 00.86^{\prime} \mathrm{W}$ \\
\hline $\begin{array}{l}\text { POS536_60- } \\
\text { 1_OP-4 }\end{array}$ & NA & C-D & 23.08 .2019 & $18: 14$ & $33^{\circ} 42.33^{\prime} \mathrm{N}$ & $39^{\circ} 48.95^{\prime} \mathrm{W}$ \\
\hline $\begin{array}{l}\text { POS536_69- } \\
\text { 1_OP-5 }\end{array}$ & NA & $\mathrm{D}$ & 24.08 .2019 & $18: 15$ & $34^{\circ} 34.36^{\prime} \mathrm{N}$ & $39^{\circ} 26.84^{\prime} \mathrm{W}$ \\
\hline $\begin{array}{l}\text { POS536_81- } \\
\text { 1_OP-6 }\end{array}$ & NA & D-E & 25.08 .2019 & $18: 15$ & $33^{\circ} 22.13^{\prime} \mathrm{N}$ & $39^{\circ} 04.04^{\prime} \mathrm{W}$ \\
\hline $\begin{array}{l}\text { POS536_102- } \\
\text { 1_OP-7 }\end{array}$ & NA & E-F & 26.08 .2019 & $18: 15$ & $33^{\circ} 08.968^{\prime} \mathrm{N}$ & $39^{\circ} 00.031^{\prime} \mathrm{W}$ \\
\hline $\begin{array}{l}\text { POS536_109- } \\
\text { 1_OP-8 }\end{array}$ & NA & E-F & 27.08 .2019 & $18: 15$ & $33^{\circ} 51.46^{\prime} \mathrm{N}$ & $39^{\circ} 23.51^{\prime} \mathrm{W}$ \\
\hline $\begin{array}{l}\text { POS536_121- } \\
\text { 1_OP-9 }\end{array}$ & NA & $\mathrm{F}$ & 28.08 .2019 & $18: 05$ & $34^{\circ} 19.38^{\prime} \mathrm{N}$ & $38^{\circ} 30.29^{\prime} \mathrm{W}$ \\
\hline $\begin{array}{l}\text { POS536_133- } \\
\text { 1_OP-10 }\end{array}$ & NA & $\mathrm{G}$ & 29.08 .2019 & $18: 05$ & $33^{\circ} 00.479^{\prime} \mathrm{N}$ & $37^{\circ} 58.040^{\prime} \mathrm{W}$ \\
\hline $\begin{array}{l}\text { POS536_149- } \\
\text { 1_OP-11 }\end{array}$ & NA & $\mathrm{H}$ & 30.08 .2019 & $18: 15$ & $34^{\circ} 38.939^{\prime} \mathrm{N}$ & $37^{\circ} 30.134^{\prime} \mathrm{W}$ \\
\hline $\begin{array}{l}\text { POS536_163- } \\
\text { 1_OP-12 }\end{array}$ & NA & H-I & 31.08 .2019 & $18: 34$ & $34^{\circ} 19,19^{\prime} \mathrm{N}$ & $37^{\circ} 23.34^{\prime} \mathrm{W}$ \\
\hline $\begin{array}{l}\text { POS536_180- } \\
\text { 1_OP-13 }\end{array}$ & NA & I-J & 01.09 .2019 & $18: 00$ & $33^{\circ} 08.92^{\prime} \mathrm{N}$ & $37^{\circ} 00.26^{\prime} \mathrm{W}$ \\
\hline $\begin{array}{l}\text { POS536_192- } \\
\text { 1_OP-14 }\end{array}$ & NA & $\mathrm{J}$ & 02.09 .2019 & $18: 00$ & $34^{\circ} 14.528^{\prime} \mathrm{N}$ & $37^{\circ} 01.409^{\prime} \mathrm{W}$ \\
\hline $\begin{array}{l}\text { POS536_202- } \\
\text { 1_OP-15 }\end{array}$ & NA & $\mathrm{J}-\mathrm{K}$ & 03.09 .2019 & $18: 15$ & $33^{\circ} 20.557^{\prime} \mathrm{N}$ & $036^{\circ} 01.258^{\prime} \mathrm{W}$ \\
\hline $\begin{array}{l}\text { POS536_216- } \\
\text { 1_OP-16 }\end{array}$ & NA & $\mathrm{K}$ & 04.09 .2019 & $18: 15$ & $33^{\circ} 09.916^{\prime} \mathrm{N}$ & $033^{\circ} 52.464^{\prime} \mathrm{W}$ \\
\hline $\begin{array}{l}\text { POS536_220- } \\
\text { 1_OP-17 }\end{array}$ & NA & Transit & 05.09 .2019 & $18: 00$ & $33^{\circ} 46.32^{\prime} \mathrm{N}$ & $30^{\circ} 19.08^{\prime} \mathrm{W}$ \\
\hline $\begin{array}{l}\text { POS536_221- } \\
\text { 1_OP-18 }\end{array}$ & NA & Transit & 06.09 .2019 & $10: 00$ & $34^{\circ} 14.34^{\prime} \mathrm{N}$ & $29^{\circ} 42.71^{\prime} \mathrm{W}$ \\
\hline
\end{tabular}

\section{Ship's Meteorological Station}

No data were collected about the ship's meterological station on POS536. 


\section{Station list POS 536}

Table 7.1: Summary of all research activities and stations during POS536. UWS = Underway water sample, NA = not available.

\begin{tabular}{|c|c|c|c|c|c|c|c|c|c|c|}
\hline Station & DShip & Area & Date & Time & Gear & Latitude (start) & $\begin{array}{l}\begin{array}{l}\text { Longitude } \\
\text { (start) }\end{array} \\
\end{array}$ & $\begin{array}{l}\begin{array}{l}\text { Latitude } \\
\text { (end) }\end{array} \\
\end{array}$ & $\begin{array}{l}\begin{array}{l}\text { Longitude } \\
\text { (end) }\end{array} \\
\end{array}$ & Status/Comment \\
\hline 1 & POS536_1-1 & $\mathrm{A}$ & 18.08 .2019 & $18: 17$ & Neuston Trawl & $35^{\circ} 34.984^{\prime} \mathrm{N}$ & $031^{\circ} 04.929^{\prime} \mathrm{W}$ & $35^{\circ} 35.942^{\prime} \mathrm{N}$ & $031^{\circ} 06.014^{\prime} \mathrm{W}$ & \\
\hline 2 & POS536_2-1 & A & 18.08 .2019 & $\begin{array}{ll}18: 56 \\
\end{array}$ & Neuston Trawl & $35^{\circ} 35.021^{\prime} \mathrm{N}$ & $031^{\circ} 07.405^{\prime} \mathrm{W}$ & $35^{\circ} 35.905^{\prime} \mathrm{N}$ & $031^{\circ} 08.429^{\prime} \mathrm{W}$ & \\
\hline 3 & POS536_3-1 & A & 18.08 .2019 & $19: 33$ & Neuston Trawl & $35^{\circ} 34.261^{\prime} \mathrm{N}$ & $031^{\circ} 09.178^{\prime} \mathrm{W}$ & $35^{\circ} 35.348^{\prime} \mathrm{N}$ & $031^{\circ} 09.938^{\prime} \mathrm{W}$ & \\
\hline 4 & POS536_4-1 & $\mathrm{A}$ & 18.08 .2019 & $22: 58$ & Neuston Trawl & $35^{\circ} 22.563^{\prime} \mathrm{N}$ & $031^{\circ} 37.507^{\prime} \mathrm{W}$ & $35^{\circ} 23.872^{\prime} \mathrm{N}$ & $031^{\circ} 37.949^{\prime} \mathrm{W}$ & \\
\hline 5 & POS536_5-1 & A & 18.08 .2019 & $23: 47$ & Neuston Trawl & $35^{\circ} 22.239^{\prime} \mathrm{N}$ & $031^{\circ} 39.517^{\prime} \mathrm{W}$ & $35^{\circ} 23.680^{\prime} \mathrm{N}$ & $031^{\circ} 39.484^{\prime} \mathrm{W}$ & \\
\hline 6 & POS536_6-1 & A & 19.08 .2019 & 00:30 & Neuston Trawl & $35^{\circ} 22.295^{\prime} \mathrm{N}$ & $031^{\circ} 40.829^{\prime} \mathrm{W}$ & $35^{\circ} 23.809^{\prime} \mathrm{N}$ & $031^{\circ} 40.885^{\prime} \mathrm{W}$ & \\
\hline 7 & POS536_0_Underway-1 & A & $\begin{array}{l}19.08 .2019 \\
\end{array}$ & 08:00 & Monitoring & $34^{\circ} 46.756^{\prime} \mathrm{N}$ & $32^{\circ} 27.550^{\prime} \mathrm{W}$ & $34^{\circ} 46.011^{\prime} \mathrm{N}$ & $32^{\circ} 31.689^{\prime} \mathrm{W}$ & \\
\hline 8 & POS536_7-1 & $\mathrm{A}$ & $\begin{array}{l}19.08 .2019 \\
\end{array}$ & $08: 27$ & Neuston Trawl & $34^{\circ} 45.189^{\prime} \mathrm{N}$ & $032^{\circ} 30.141^{\prime} \mathrm{W}$ & $34^{\circ} 46.530^{\prime} \mathrm{N}$ & $032^{\circ} 30.891^{\prime} \mathrm{W}$ & \\
\hline 9 & POS536_0_Underway-2 & A & 19.08 .2019 & 09:00 & Monitoring & $34^{\circ} 45.907^{\prime} \mathrm{N}$ & $32^{\circ} 32.061^{\prime} \mathrm{W}$ & $34^{\circ} 47.778^{\prime} \mathrm{N}$ & $032^{\circ} 34.965^{\prime} \mathrm{W}$ & \\
\hline 10 & POS536_8-1 & $\mathrm{A}$ & $\begin{array}{l}19.08 .2019 \\
\end{array}$ & 09:07 & Neuston Trawl & $34^{\circ} 46.037^{\prime} \mathrm{N}$ & $032^{\circ} 32.116^{\prime} \mathrm{W}$ & $34^{\circ} 47.410^{\prime} \mathrm{N}$ & $032^{\circ} 32.998^{\prime} \mathrm{W}$ & \\
\hline 11 & POS536_9-1 & $\mathrm{A}$ & 19.08 .2019 & $09: 45$ & Neuston Trawl & $34^{\circ} 46.630^{\prime} \mathrm{N}$ & $032^{\circ} 34.255^{\prime} \mathrm{W}$ & $34^{\circ} 47.966^{\prime} \mathrm{N}$ & $032^{\circ} 35.101^{\prime} \mathrm{W}$ & \\
\hline 12 & POS536_0_Underway-2 & $\mathrm{A}$ & $\begin{array}{l}19.08 .2019 \\
\end{array}$ & $\begin{array}{l}2: 00 \\
\end{array}$ & Monitoring & $34^{\circ} 34.880^{\prime} \mathrm{N}$ & $32^{\circ} 47.328^{\prime} \mathrm{W}$ & $34^{\circ} 27.530^{\prime} \mathrm{N}$ & $32^{\circ} 54.034^{\prime} \mathrm{W}$ & \\
\hline 13 & POS536_0_Underway-2 & $\mathrm{A}$ & $\begin{array}{l}19.08 .2019 \\
\end{array}$ & 13:00 & Monitoring & $34^{\circ} 27.197^{\prime} \mathrm{N}$ & $32^{\circ} 54.342^{\prime} \mathrm{W}$ & $34^{\circ} 19.852^{\prime} \mathrm{N}$ & $33^{\circ} 01.039^{\prime} \mathrm{W}$ & \\
\hline 14 & POS536_10-1 & $\mathrm{A}$ & 19.08 .2019 & $15: 31$ & Neuston Trawl & $34^{\circ} 10.098^{\prime} \mathrm{N}$ & $033^{\circ} 09.991^{\prime} \mathrm{W}$ & $34^{\circ} 11.504^{\prime} \mathrm{N}$ & $033^{\circ} 10.641^{\prime} \mathrm{W}$ & \\
\hline 15 & POS536_0_Underway-2 & A & 19.08.2019 & $15: 30$ & Monitoring & $34^{\circ} 10.122^{\prime} \mathrm{N}$ & $33^{\circ} 09.997^{\prime} \mathrm{W}$ & $34^{\circ} 11.152^{\prime} \mathrm{N}$ & $33^{\circ} 12.553^{\prime} \mathrm{W}$ & \\
\hline 16 & POS536_11-1 & $\mathrm{A}$ & $\begin{array}{l}19.08 .2019 \\
\end{array}$ & $\begin{array}{l}16: 09 \\
\end{array}$ & Neuston Trawl & $34^{\circ} 10.156^{\prime} \mathrm{N}$ & $033^{\circ} 11.554^{\prime} \mathrm{W}$ & $34^{\circ} 11.149^{\prime} \mathrm{N}$ & $033^{\circ} 12.550^{\prime} \mathrm{W}$ & \\
\hline 17 & POS536_12-1 & $\mathrm{A}$ & 19.08.2019 & $16: 48$ & Neuston Trawl & $34^{\circ} 09.428^{\prime} \mathrm{N}$ & $033^{\circ} 13.343^{\prime} \mathrm{W}$ & $34^{\circ} 10.508^{\prime} \mathrm{N}$ & $033^{\circ} 14.139^{\prime} \mathrm{W}$ & \\
\hline 18 & POS536_0_Underway-2 & $\mathrm{A}$ & 19.08 .2019 & $\begin{array}{l}16: 30 \\
\end{array}$ & Monitoring & $34^{\circ} 11.185^{\prime} \mathrm{N}$ & $33^{\circ} 12.594^{\prime} \mathrm{W}$ & $34^{\circ} 08.890^{\prime} \mathrm{N}$ & $33^{\circ} 16.517^{\prime} \mathrm{W}$ & \\
\hline 19 & $\mathrm{NA}$ & $\mathrm{A}$ & 19.08 .2019 & $18: 18$ & $\begin{array}{l}\text { Ocean Pack } \\
\end{array}$ & $\begin{array}{l}35^{\circ} 35.02 \mathrm{~N} \\
\text { (possibly } \\
\text { erroneous) }\end{array}$ & $031^{\circ} 04.97^{\prime} \mathrm{W}$ & $\mathrm{NA}$ & $\mathrm{NA}$ & \\
\hline 20 & POS536_13-1 & B & 20.08 .2019 & 02:30 & Neuston Trawl & $33^{\circ} 15.193^{\prime} \mathrm{N}$ & $034^{\circ} 29.977^{\prime} \mathrm{W}$ & $33^{\circ} 16.338^{\prime} \mathrm{N}$ & $034^{\circ} 31.328^{\prime} \mathrm{W}$ & \\
\hline 21 & POS536_14-1 & B & 20.08 .2019 & 03:09 & Neuston Trawl & $33^{\circ} 15.317^{\prime} \mathrm{N}$ & $034^{\circ} 31.907^{\prime} \mathrm{W}$ & $33^{\circ} 16.750^{\prime} \mathrm{N}$ & $034^{\circ} 33.048^{\prime} \mathrm{W}$ & \\
\hline 22 & POS536_15-1 & $\mathrm{B}$ & 20.08 .2019 & $03: 51$ & Neuston Trawl & $33^{\circ} 15.704^{\prime} \mathrm{N}$ & $034^{\circ} 33.479^{\prime} \mathrm{W}$ & $33^{\circ} 16.860^{\prime} \mathrm{N}$ & $034^{\circ} 34.876^{\prime} \mathrm{W}$ & \\
\hline 23 & POS536_16-1 & B & 20.08 .2019 & $04: 34$ & Bongo Net & $33^{\circ} 16.458^{\prime} \mathrm{N}$ & $034^{\circ} 34.723^{\prime} \mathrm{W}$ & $33^{\circ} 16.051^{\prime} \mathrm{N}$ & $034^{\circ} 36.155^{\prime} \mathrm{W}$ & \\
\hline 24 & POS536_17-1 & B & 20.08 .2019 & $05: 25$ & Bongo Net & $33^{\circ} 15.858^{\prime} \mathrm{N}$ & $034^{\circ} 33.317^{\prime} \mathrm{W}$ & $33^{\circ} 16.647^{\prime} \mathrm{N}$ & $034^{\circ} 35.991^{\prime} \mathrm{W}$ & \\
\hline 25 & POS536_18-1 & B & 20.08 .2019 & $06: 36$ & Bongo Net & $33^{\circ} 15.748^{\prime} \mathrm{N}$ & $034^{\circ} 33.869^{\prime} \mathrm{W}$ & $33^{\circ} 16.346^{\prime} \mathrm{N}$ & $034^{\circ} 38.284^{\prime} \mathrm{W}$ & \\
\hline 26 & POS536_19-1 & B & 20.08 .2019 & 08:31 & WP2 Net & $33^{\circ} 15.701^{\prime} \mathrm{N}$ & $034^{\circ} 33.497^{\prime} \mathrm{W}$ & $33^{\circ} 16.382^{\prime} \mathrm{N}$ & $034^{\circ} 33.419^{\prime} \mathrm{W}$ & \\
\hline 27 & POS536_20-1 & B & 20.08 .2019 & $09: 10$ & WP2 Net & $33^{\circ} 16.478^{\prime} \mathrm{N}$ & $034^{\circ} 33.408^{\prime} \mathrm{W}$ & $33^{\circ} 17.390^{\prime} \mathrm{N}$ & $034^{\circ} 33.053^{\prime} \mathrm{W}$ & \\
\hline
\end{tabular}




\begin{tabular}{|c|c|c|c|c|c|c|c|c|c|c|}
\hline Station & DShip & Area & Date & Time & Gear & Latitude (start) & $\begin{array}{l}\begin{array}{l}\text { Longitude } \\
\text { (start) }\end{array}\end{array}$ & $\begin{array}{l}\text { Latitude } \\
\text { (end) }\end{array}$ & $\begin{array}{l}\begin{array}{l}\text { Longitude } \\
\text { (end) }\end{array} \\
\text { (a) }\end{array}$ & Status/Comment \\
\hline 28 & POS536_21-1 & B & 20.08 .2019 & 10:03 & WP2 Net & $33^{\circ} 17.456^{\prime} \mathrm{N}$ & $034^{\circ} 33.027^{\prime} \mathrm{W}$ & $33^{\circ} 18.812^{\prime} \mathrm{N}$ & $034^{\circ} 32.251^{\prime} \mathrm{W}$ & \\
\hline 29 & $\mathrm{NA}$ & A & 19.08 .2019 & $09: 15$ & UWS & $35^{\circ} 35.74 \mathrm{~N}$ & $31^{\circ} 05.82^{\prime} \mathrm{W}$ & $\mathrm{NA}$ & NA & \\
\hline 30 & POS536_22-1 & B & 20.08 .2019 & $12: 29$ & CTD & $33^{\circ} 16.128^{\prime} \mathrm{N}$ & $034^{\circ} 33.343^{\prime} \mathrm{W}$ & $33^{\circ} 17.101^{\prime} \mathrm{N}$ & $034^{\circ} 32.598^{\prime} \mathrm{W}$ & \\
\hline 31 & POS536_23-1 & B & 20.08 .2019 & 14:00 & CTD & $33^{\circ} 17.682^{\prime} \mathrm{N}$ & $034^{\circ} 32.282^{\prime} \mathrm{W}$ & $33^{\circ} 17.826^{\prime} \mathrm{N}$ & $034^{\circ} 32.152^{\prime} \mathrm{W}$ & \\
\hline 32 & POS536_24-1 & B & 20.08 .2019 & 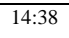 & CTD & $33^{\circ} 18.287^{\prime} \mathrm{N}$ & $034^{\circ} 31.947^{\prime} \mathrm{W}$ & $33^{\circ} 18.464^{\prime} \mathrm{N}$ & $034^{\circ} 31.793^{\prime} \mathrm{W}$ & \\
\hline 33 & POS536_25-1 & B & 20.08 .2019 & 15:09 & CTD & $33^{\circ} 18.720^{\prime} \mathrm{N}$ & $034^{\circ} 31.579^{\prime} \mathrm{W}$ & $33^{\circ} 18.917^{\prime} \mathrm{N}$ & $034^{\circ} 31.393^{\prime} \mathrm{W}$ & \\
\hline 34 & POS536_26-1 & B & 20.08 .2019 & $16: 24$ & CTD/INSITU Pumps & $33^{\circ} 15.108^{\prime} \mathrm{N}$ & $034^{\circ} 29.943^{\prime} \mathrm{W}$ & $33^{\circ} 17.564^{\prime} \mathrm{N}$ & $034^{\circ} 29.724^{\prime} \mathrm{W}$ & $\begin{array}{l}\text { At the same time } 3 \text { Oceanpack filters } \\
\text { were changed, but no station number } \\
\text { was assigned to them }\end{array}$ \\
\hline 35 & $\begin{array}{l}\text { POS536_0_Underway-2 } \\
\end{array}$ & B-C & 21.08 .2019 & 08:00 & Monitoring & $33^{\circ} 14.873^{\prime} \mathrm{N}$ & $36^{\circ} 15.452^{\prime} \mathrm{W}$ & $33^{\circ} 14.363^{\prime} \mathrm{N}$ & $36^{\circ} 25.606^{\prime} \mathrm{W}$ & \\
\hline 36 & $\begin{array}{l}\text { POS536_0_Underway-2 } \\
\end{array}$ & B-C & 21.08 .2019 & 09:00 & Monitoring & $33^{\circ} 14.334^{\prime} \mathrm{N}$ & $36^{\circ} 25.789^{\prime} \mathrm{W}$ & $33^{\circ} 12.616^{\prime} \mathrm{N}$ & $36^{\circ} 35.660^{\prime} \mathrm{W}$ & \\
\hline 37 & $\begin{array}{l}\text { POS536_0_Underway-2 } \\
\end{array}$ & B-C & 21.08 .2019 & 12:00 & Monitoring & $33^{\circ} 09.179^{\prime} \mathrm{N}$ & $36^{\circ} 54.823^{\prime} \mathrm{W}$ & $33^{\circ} 07.224^{4} \mathrm{~N}$ & $37^{\circ} 04.077^{\prime} \mathrm{W}$ & \\
\hline 38 & POS536_0_Underway-2 & B-C & 21.08 .2019 & 13:00 & Monitoring & $33^{\circ} 07.207^{\prime} \mathrm{N}$ & $37^{\circ} 04.150^{\prime} \mathrm{W}$ & $33^{\circ} 05.475^{\prime} \mathrm{N}$ & $37^{\circ} 13.077^{\prime} \mathrm{W}$ & \\
\hline 39 & $\begin{array}{l}\text { POS536_0_Underway-2 } \\
\end{array}$ & B-C & 21.08 .2019 & $15: 30$ & Monitoring & $33^{\circ} 03.390^{\prime} \mathrm{N}$ & $37^{\circ} 26.891^{\prime} \mathrm{W}$ & $33^{\circ} 01.888^{\prime} \mathrm{N}$ & $37^{\circ} 36.010^{\prime} \mathrm{W}$ & \\
\hline 40 & POS536_0_Underway-2 & B-C & 21.08 .2019 & 16:30 & Monitoring & $33^{\circ} 01.875^{\prime} \mathrm{N}$ & $037^{\circ} 36.073^{\prime} \mathrm{W}$ & $33^{\circ} 00.355^{\prime} \mathrm{N}$ & $37^{\circ} 45.414^{\prime} \mathrm{W}$ & \\
\hline 41 & $\mathrm{NA}$ & B-C & 21.08 .2019 & $18: 15$ & $\begin{array}{l}\text { Ocean Pack } \\
\end{array}$ & $32^{\circ} 59.21^{\prime} \mathrm{N}$ & $37^{\circ} 52.85^{`} \mathrm{~W}$ & $\mathrm{NA}$ & $\mathrm{NA}$ & \\
\hline 42 & POS536_27-1 & $\mathrm{C}$ & 22.08 .2019 & 09:50 & Sediment Traps & $33^{\circ} 09.086^{\prime} \mathrm{N}$ & $39^{\circ} 59.687^{\prime} \mathrm{W}$ & $33^{\circ} 24.455^{\prime} \mathrm{N}$ & $40^{\circ} 13.788^{\prime} \mathrm{W}$ & \\
\hline 43 & POS536_28-1 & $\mathrm{C}$ & 22.08 .2019 & $12: 58$ & Box Corer & $33^{\circ} 09.327^{\prime} \mathrm{N}$ & $039^{\circ} 59.997^{\prime} \mathrm{W}$ & $33^{\circ} 09.571^{\prime} \mathrm{N}$ & $040^{\circ} 00.463^{\prime} \mathrm{W}$ & \\
\hline 44 & POS536_29-1 & $\mathrm{C}$ & 22.08 .2019 & 15:00 & Multicorer & $33^{\circ} 09.622^{\prime} \mathrm{N}$ & $040^{\circ} 00.650^{\prime} \mathrm{W}$ & $33^{\circ} 09.660^{\prime} \mathrm{N}$ & $040^{\circ} 00.769^{\prime} \mathrm{W}$ & fail \\
\hline 45 & $\mathrm{NA}$ & $\mathrm{C}$ & 22.08 .2019 & $18: 15$ & Ocean Pack & $33^{\circ} 09.81^{\prime} \mathrm{N}$ & $40^{\circ} 00.86^{\prime} \mathrm{W}$ & NA & NA & \\
\hline 46 & POS536_30-1 & $\mathrm{C}$ & 23.08 .2019 & 00:02 & Neuston Trawl & $33^{\circ} 09.369^{\prime} \mathrm{N}$ & $039^{\circ} 59.894^{\prime} \mathrm{W}$ & $33^{\circ} 10.836^{\prime} \mathrm{N}$ & $040^{\circ} 00.360^{\prime} \mathrm{W}$ & \\
\hline 47 & POS536_31-1 & $\mathrm{C}$ & 23.08 .2019 & $00: 40$ & Neuston Trawl & $33^{\circ} 10.55^{\prime} \mathrm{N}$ & $40^{\circ} 00.77^{\prime} \mathrm{W}$ & $33^{\circ} 12.18^{\prime} \mathrm{N}$ & $40^{\circ} 01.15^{\prime} \mathrm{W}$ & \\
\hline 48 & POS536_32-1 & $\mathrm{C}$ & 23.08 .2019 & $01: 19$ & Neuston Trawl & $33^{\circ} 11.43^{\prime} \mathrm{N}$ & $40^{\circ} 01.55^{\prime} \mathrm{W}$ & $33^{\circ} 13.00^{\prime} \mathrm{N}$ & $40^{\circ} 02.01 ' \mathrm{~W}$ & \\
\hline 49 & POS536_33-1 & $\mathrm{C}$ & 23.08 .2019 & $02: 29$ & Bongo Net & $33^{\circ} 09.05^{\prime} \mathrm{N}$ & $39^{\circ} 59.88^{\prime} \mathrm{W}$ & $33^{\circ} 10.71 ' \mathrm{~N}$ & $39^{\circ} 59.75^{\prime} \mathrm{W}$ & \\
\hline 50 & POS536_34-1 & $\mathrm{C}$ & 23.08 .2019 & $03: 24$ & Bongo Net & $33^{\circ} 09.016^{\prime} \mathrm{N}$ & $039^{\circ} 59.969^{\prime} \mathrm{W}$ & $33^{\circ} 10.415^{\prime} \mathrm{N}$ & $039^{\circ} 59.952^{\prime} \mathrm{W}$ & \\
\hline 51 & POS536_35-1 & $\mathrm{C}$ & 23.08 .2019 & $04: 29$ & Bongo Net & $33^{\circ} 08.979^{\prime} \mathrm{N}$ & $039^{\circ} 59.915^{\prime} \mathrm{W}$ & $33^{\circ} 11.347^{\prime} \mathrm{N}$ & $039^{\circ} 59.801^{\prime} \mathrm{W}$ & \\
\hline 52 & POS536_36-1 & $\mathrm{C}$ & 23.08.2019 & $06: 17$ & WP2 Net & $33^{\circ} 09.113^{\prime} \mathrm{N}$ & $039^{\circ} 59.887^{\prime} \mathrm{W}$ & $33^{\circ} 09.250^{\prime} \mathrm{N}$ & $039^{\circ} 59.840^{\prime} \mathrm{W}$ & \\
\hline 53 & POS536_37-1 & $\mathrm{C}$ & 23.08 .2019 & $06: 54$ & WP2 Net & $33^{\circ} 08.814^{\prime} \mathrm{N}$ & $039^{\circ} 59.911^{\prime} \mathrm{W}$ & $33^{\circ} 08.965^{\prime} \mathrm{N}$ & $039^{\circ} 59.874^{\prime} \mathrm{W}$ & \\
\hline 54 & POS536_38-1 & $\mathrm{C}$ & 23.08 .2019 & $07: 56$ & WP2 Net & $33^{\circ} 08.969^{\prime} \mathrm{N}$ & $039^{\circ} 59.875^{\prime} \mathrm{W}$ & $33^{\circ} 08.886^{\prime} \mathrm{N}$ & $039^{\circ} 59.861^{\prime} \mathrm{W}$ & \\
\hline 55 & POS536_39-1 & $\mathrm{C}$ & 23.08 .2019 & $09: 56$ & CTD & $33^{\circ} 08.877^{\prime} \mathrm{N}$ & $039^{\circ} 59.908^{\prime} \mathrm{W}$ & $33^{\circ} 08.820^{\prime} \mathrm{N}$ & $039^{\circ} 59.965^{\prime} \mathrm{W}$ & \\
\hline 56 & POS536_40-1 & C & 23.08.2019 & 11:59 & Multicorer & $33^{\circ} 08.867^{\prime} \mathrm{N}$ & $039^{\circ} 59.984^{\prime} \mathrm{W}$ & $33^{\circ} 08.841^{\prime} \mathrm{N}$ & $040^{\circ} 00.073^{\prime} \mathrm{W}$ & fail \\
\hline 57 & $\begin{array}{l}\text { POS536_0_Underway-2 } \\
\end{array}$ & C-D & 23.08 .2019 & $15: 30$ & Monitoring & $33^{\circ} 21.697^{\prime} \mathrm{N}$ & $039^{\circ} 55.798^{\prime} \mathrm{W}$ & $33^{\circ} 29.728^{\prime} \mathrm{N}$ & $039^{\circ} 53.137^{\prime} \mathrm{W}$ & \\
\hline 58 & $\begin{array}{l}\text { POS536_0_Underway-2 } \\
\end{array}$ & C-D & 23.08 .2019 & 16:30 & Monitoring & $33^{\circ} 29.789^{\prime} \mathrm{N}$ & $039^{\circ} 53.117^{\prime} \mathrm{W}$ & $33^{\circ} 38.011^{\prime} \mathrm{N}$ & $039^{\circ} 50.383^{\prime} \mathrm{W}$ & \\
\hline 59 & $\mathrm{NA}$ & C-D & 23.08 .2019 & $18: 14$ & $\begin{array}{l}\text { Ocean Pack } \\
\end{array}$ & $33^{\circ} 42.33^{\prime} \mathrm{N}$ & $39^{\circ} 48.95^{\prime} \mathrm{W}$ & NA & NA & \\
\hline
\end{tabular}




\begin{tabular}{|c|c|c|c|c|c|c|c|c|c|c|}
\hline Station & DShip & Area & Date & Time & Gear & Latitude (start) & $\begin{array}{l}\begin{array}{l}\text { Longitude } \\
\text { (start) }\end{array} \\
\end{array}$ & $\begin{array}{l}\begin{array}{l}\text { Latitude } \\
\text { (end) }\end{array} \\
\end{array}$ & $\begin{array}{l}\begin{array}{l}\text { Longitude } \\
\text { (end) }\end{array} \\
\end{array}$ & Status/Comment \\
\hline 60 & POS536_0_Underway-2 & C-D & 23.08 .2019 & 19:00 & Monitoring & $33^{\circ} 50.309^{\prime} \mathrm{N}$ & $039^{\circ} 46.291^{\prime} \mathrm{W}$ & $33^{\circ} 58.760^{\prime} \mathrm{N}$ & $039^{\circ} 43.485^{\prime} \mathrm{W}$ & \\
\hline 61 & $\begin{array}{l}\text { POS536_0_Underway-2 } \\
\end{array}$ & C-D & 23.08 .2019 & $20: 00$ & Monitoring & $33^{\circ} 58.822^{\prime} \mathrm{N}$ & $039^{\circ} 43.464^{\prime} \mathrm{W}$ & $34^{\circ} 07.267^{\prime} \mathrm{N}$ & $039^{\circ} 40.630^{\prime} \mathrm{W}$ & \\
\hline 62 & POS536_41-1 & $\mathrm{D}$ & 24.08 .2019 & $01: 36$ & CTD/INSITU Pumps & $34^{\circ} 38.611^{\prime} \mathrm{N}$ & $039^{\circ} 27.801^{\prime} \mathrm{W}$ & $34^{\circ} 38.676^{\prime} \mathrm{N}$ & $039^{\circ} 28.616^{\prime} \mathrm{W}$ & \\
\hline 63 & POS536_42-1 & $\mathrm{D}$ & 24.08 .2019 & $08: 14$ & Box Corer & $34^{\circ} 38.584^{\prime} \mathrm{N}$ & $039^{\circ} 27.827^{\prime} \mathrm{W}$ & $34^{\circ} 38.584^{\prime} \mathrm{N}$ & $039^{\circ} 27.872^{\prime} \mathrm{W}$ & \\
\hline 64 & POS536_43-1 & $\mathrm{D}$ & 24.08 .2019 & $11: 55$ & Multicorer & $34^{\circ} 38.522^{\prime} \mathrm{N}$ & $039^{\circ} 27.709^{\prime} \mathrm{W}$ & $34^{\circ} 38.507^{\prime} \mathrm{N}$ & $039^{\circ} 27.757^{\prime} \mathrm{W}$ & fail \\
\hline 65 & POS536_44-1 & $\mathrm{D}$ & 24.08 .2019 & 13:49 & Multicorer & $34^{\circ} 38.498^{\prime} \mathrm{N}$ & $039^{\circ} 27.739^{\prime} \mathrm{W}$ & $34^{\circ} 38.459^{\prime} \mathrm{N}$ & $039^{\circ} 27.747^{\prime} \mathrm{W}$ & fail \\
\hline 66 & POS536_45-1 & $\mathrm{D}$ & 24.08 .2019 & $15: 35$ & Neuston Trawl & $34^{\circ} 38.358^{\prime} \mathrm{N}$ & $039^{\circ} 27.738^{\prime} \mathrm{W}$ & $34^{\circ} 36.757^{\prime} \mathrm{N}$ & $039^{\circ} 27.459^{\prime} \mathrm{W}$ & \\
\hline 67 & POS536_46-1 & $\mathrm{D}$ & 24.08 .2019 & 16:09 & Neuston Trawl & $34^{\circ} 36.097^{\prime} \mathrm{N}$ & $039^{\circ} 27.346^{\prime} \mathrm{W}$ & $34^{\circ} 35.343^{\prime} \mathrm{N}$ & $039^{\circ} 27.187^{\prime} \mathrm{W}$ & \\
\hline 68 & POS536_47-1 & $\mathrm{D}$ & 24.08 .2019 & $16: 36$ & Neuston Trawl & $34^{\circ} 34.335^{\prime} \mathrm{N}$ & $039^{\circ} 26.837^{\prime} \mathrm{W}$ & $34^{\circ} 34.335^{\prime} \mathrm{N}$ & $039^{\circ} 26.837^{\prime} \mathrm{W}$ & \\
\hline 69 & NA & $\mathrm{D}$ & 24.08 .2019 & $18: 15$ & Ocean Pack & $34^{\circ} 34.36^{\prime} \mathrm{N}$ & $39^{\circ} 26.84^{\prime} \mathrm{W}$ & $\mathrm{NA}$ & $\mathrm{NA}$ & \\
\hline 70 & $\begin{array}{l}\text { POS536_48-1 } \\
\end{array}$ & $\mathrm{D}$ & 24.08 .2019 & $23: 56$ & Bongo Net & $34^{\circ} 37.687^{\prime} \mathrm{N}$ & $039^{\circ} 27.872^{\prime} \mathrm{W}$ & $34^{\circ} 36.507^{\prime} \mathrm{N}$ & $039^{\circ} 27.471^{\prime} \mathrm{W}$ & \\
\hline 71 & $\begin{array}{l}\text { POS536_49-1 } \\
\end{array}$ & $\mathrm{D}$ & 25.08 .2019 & 01:04 & Bongo Net & $34^{\circ} 38.561^{\prime} \mathrm{N}$ & $039^{\circ} 27.808^{\prime} \mathrm{W}$ & $34^{\circ} 36.791^{\prime} \mathrm{N}$ & $039^{\circ} 27.481^{\prime} \mathrm{W}$ & \\
\hline 72 & POS536_50-1 & $\mathrm{D}$ & 25.08 .2019 & $02: 22$ & Bongo Net & $34^{\circ} 38.506^{\prime} \mathrm{N}$ & $039^{\circ} 27.788^{\prime} \mathrm{W}$ & $34^{\circ} 35.846^{\prime} \mathrm{N}$ & $039^{\circ} 27.439^{\prime} \mathrm{W}$ & \\
\hline 73 & POS536_51-1 & $\mathrm{D}$ & 25.08 .2019 & $04: 16$ & WP2 Net & $34^{\circ} 38.674^{\prime} \mathrm{N}$ & $039^{\circ} 27.896^{\prime} \mathrm{W}$ & $34^{\circ} 38.607^{\prime} \mathrm{N}$ & $039^{\circ} 27.933^{\prime} \mathrm{W}$ & \\
\hline 74 & POS536_52-1 & $\mathrm{D}$ & 25.08 .2019 & $04: 49$ & WP2 Net & $34^{\circ} 38.605^{\prime} \mathrm{N}$ & $039^{\circ} 27.964^{\prime} \mathrm{W}$ & $34^{\circ} 38.520^{\prime} \mathrm{N}$ & $039^{\circ} 28.082^{\prime} \mathrm{W}$ & \\
\hline 75 & POS536_53-1 & $\mathrm{D}$ & 25.08 .2019 & $05: 48$ & WP2 Net & $34^{\circ} 38.535^{\prime} \mathrm{N}$ & $039^{\circ} 28.062^{\prime} \mathrm{W}$ & $34^{\circ} 38.490^{\prime} \mathrm{N}$ & $039^{\circ} 28.174^{\prime} \mathrm{W}$ & \\
\hline 76 & POS536_54-1 & $\mathrm{D}$ & 25.08 .2019 & $07: 16$ & CTD & $34^{\circ} 38.503^{\prime} \mathrm{N}$ & $039^{\circ} 28.113^{\prime} \mathrm{W}$ & $34^{\circ} 38.589^{\prime} \mathrm{N}$ & $039^{\circ} 27.915^{\prime} \mathrm{W}$ & \\
\hline 77 & POS536_0_Underway-2 & $\mathrm{D}$ & 25.08 .2019 & 12:00 & Monitoring & $34^{\circ} 08.943^{\prime} \mathrm{N}$ & $39^{\circ} 18.538^{\prime} \mathrm{W}$ & $34^{\circ} 01.025^{\prime} \mathrm{N}$ & $39^{\circ} 16.070^{\prime} \mathrm{W}$ & \\
\hline 78 & POS536_0_Underway-2 & $\mathrm{D}$ & 25.08 .2019 & 13:00 & Monitoring & $34^{\circ} 00.958^{\prime} \mathrm{N}$ & $39^{\circ} 16.050^{\prime} \mathrm{W}$ & $33^{\circ} 52.973^{\prime} \mathrm{N}$ & $39^{\circ} 13.573^{\prime} \mathrm{W}$ & \\
\hline 79 & POS536_0_Underway-2 & $\mathrm{D}$ & 25.08 .2019 & $15: 30$ & Monitoring & $33^{\circ} 41.690^{\prime} \mathrm{N}$ & $39^{\circ} 10.079^{\prime} \mathrm{W}$ & $33^{\circ} 34.254^{\prime} \mathrm{N}$ & $39^{\circ} 07.775^{\prime} \mathrm{W}$ & \\
\hline 80 & POS536_0_Underway-2 & $\mathrm{D}$ & 25.08 .2019 & $16: 30$ & Monitoring & $33^{\circ} 34.188^{\prime} \mathrm{N}$ & $39^{\circ} 07.756^{\prime} \mathrm{W}$ & $33^{\circ} 26.583^{\prime} \mathrm{N}$ & $39^{\circ} 05.409^{\prime} \mathrm{W}$ & \\
\hline 81 & $\mathrm{NA}$ & D-E & 25.08 .2019 & $18: 15$ & Ocean Pack & $33^{\circ} 22.13^{\prime} \mathrm{N}$ & $39^{\circ} 04.04^{\prime} \mathrm{W}$ & $\mathrm{NA}$ & $\mathrm{NA}$ & \\
\hline 82 & POS536_0_Underway-2 & D-E & 25.08 .2019 & $\begin{array}{l}18: 00 \\
\end{array}$ & Monitoring & $33^{\circ} 22.865^{\prime} \mathrm{N}$ & $39^{\circ} 04.269^{\prime} \mathrm{W}$ & $33^{\circ} 15.461^{\prime} \mathrm{N}$ & $39^{\circ} 01.987^{\prime} \mathrm{W}$ & \\
\hline 83 & POS536_0_Underway-2 & D-E & 25.08 .2019 & 19:00 & Monitoring & $33^{\circ} 15.405^{\prime} \mathrm{N}$ & $39^{\circ} 01.968^{\prime} \mathrm{W}$ & $33^{\circ} 08.956^{\prime} \mathrm{N}$ & $38^{\circ} 59.988^{\prime} \mathrm{W}$ & \\
\hline 84 & $\mathrm{NA}$ & E & 25.08 .2019 & 20:00 & UWS & $\mathrm{NA}$ & NA & NA & NA & \\
\hline 85 & POS536_55-1 & $\mathrm{E}$ & 25.08 .2019 & 19:57 & WP2 Net & $33^{\circ} 08.988^{\prime} \mathrm{N}$ & $039^{\circ} 00.004^{\prime} \mathrm{W}$ & $33^{\circ} 08.707^{\prime} \mathrm{N}$ & $038^{\circ} 59.829^{\prime} \mathrm{W}$ & \\
\hline 86 & POS536_56-1 & E & 25.08 .2019 & $20: 27$ & WP2 Net & $33^{\circ} 08.693^{\prime} \mathrm{N}$ & $038^{\circ} 59.813^{\prime} \mathrm{W}$ & $33^{\circ} 08.388^{\prime} \mathrm{N}$ & $038^{\circ} 59.461^{\prime} \mathrm{W}$ & \\
\hline 87 & POS536_57-1 & $\mathrm{E}$ & 25.08 .2019 & $21: 22$ & WP2 Net & $33^{\circ} 08.367^{\prime} \mathrm{N}$ & $038^{\circ} 59.443^{\prime} \mathrm{W}$ & $33^{\circ} 07.975^{\prime} \mathrm{N}$ & $038^{\circ} 59.018^{\prime} \mathrm{W}$ & \\
\hline 88 & POS536_58-1 & E & 25.08 .2019 & $22: 49$ & Bongo Net & $33^{\circ} 07.908^{\prime} \mathrm{N}$ & $038^{\circ} 58.880^{\prime} \mathrm{W}$ & $33^{\circ} 07.588^{\prime} \mathrm{N}$ & $038^{\circ} 57.349^{\prime} \mathrm{W}$ & \\
\hline 89 & POS536_59-1 & E & 26.08 .2019 & 23.48 & Bongo Net & $33^{\circ} 08.174^{\prime} \mathrm{N}$ & $038^{\circ} 58.738^{\prime} \mathrm{W}$ & $33^{\circ} 07.655^{\prime} \mathrm{N}$ & $038^{\circ} 57.134^{\prime} \mathrm{W}$ & \\
\hline 90 & POS536_60-1 & E & 26.08 .2019 & $00: 59$ & Bongo Net & $33^{\circ} 08.326^{\prime} \mathrm{N}$ & $038^{\circ} 58.758^{\prime} \mathrm{W}$ & $33^{\circ} 07.529^{\prime} \mathrm{N}$ & $038^{\circ} 56.426^{\prime} \mathrm{W}$ & \\
\hline 91 & POS536_61-1 & $\mathrm{E}$ & 26.08 .2019 & $02: 44$ & Neuston Trawl & $33^{\circ} 08.676^{\prime} \mathrm{N}$ & $038^{\circ} 59.411^{\prime} \mathrm{W}$ & $33^{\circ} 08.092^{\prime} \mathrm{N}$ & $038^{\circ} 57.761^{\prime} \mathrm{W}$ & \\
\hline
\end{tabular}




\begin{tabular}{|c|c|c|c|c|c|c|c|c|c|c|}
\hline Station & DShip & Area & Date & Time & Gear & Latitude (start) & $\begin{array}{l}\begin{array}{l}\text { Longitude } \\
\text { (start) }\end{array}\end{array}$ & $\begin{array}{l}\text { Latitude } \\
\text { (end) }\end{array}$ & $\begin{array}{l}\begin{array}{l}\text { Longitude } \\
\text { (end) }\end{array}\end{array}$ & Status/Comment \\
\hline 92 & POS536_62-1 & $\mathrm{E}$ & 26.08 .2019 & $03: 24$ & Neuston Trawl & $33^{\circ} 08.515^{\prime} \mathrm{N}$ & $038^{\circ} 58.179^{\prime} \mathrm{W}$ & $33^{\circ} 07.911^{\prime} \mathrm{N}$ & $038^{\circ} 56.442^{\prime} \mathrm{W}$ & \\
\hline 93 & POS536_63-1 & $\mathrm{E}$ & 26.08 .2019 & 04:04 & Neuston Trawl & $33^{\circ} 08.209^{\prime} \mathrm{N}$ & $038^{\circ} 57.089^{\prime} \mathrm{W}$ & $33^{\circ} 07.584^{\prime} \mathrm{N}$ & $038^{\circ} 55.334^{\prime} \mathrm{W}$ & \\
\hline 94 & POS536_64-1 & $\mathrm{E}$ & 26.08 .2019 & $05: 12$ & CTD & $33^{\circ} 09.015^{\prime} \mathrm{N}$ & $038^{\circ} 59.937^{\prime} \mathrm{W}$ & $33^{\circ} 08.743^{\prime} \mathrm{N}$ & $038^{\circ} 59.689^{\prime} \mathrm{W}$ & \\
\hline 95 & POS536_65-1 & $\mathrm{E}$ & 26.08 .2019 & $06: 29$ & CTD & $33^{\circ} 09.128^{\prime} \mathrm{N}$ & $038^{\circ} 59.905^{\prime} \mathrm{W}$ & $33^{\circ} 09.215^{\prime} \mathrm{N}$ & $038^{\circ} 59.970^{\prime} \mathrm{W}$ & \\
\hline 96 & POS536_66-1 & $\mathrm{E}$ & 26.08 .2019 & $08: 46$ & Box Corer & $33^{\circ} 09.130^{\prime} \mathrm{N}$ & $038^{\circ} 59.670^{\prime} \mathrm{W}$ & $33^{\circ} 09.067^{\prime} \mathrm{N}$ & $038^{\circ} 59.584^{\prime} \mathrm{W}$ & \\
\hline 97 & POS536_67-1 & $\mathrm{E}$ & 26.08 .2019 & 10:07 & Box Corer & $33^{\circ} 09.083^{\prime} \mathrm{N}$ & $038^{\circ} 59.551^{\prime} \mathrm{W}$ & $33^{\circ} 09.103^{\prime} \mathrm{N}$ & $038^{\circ} 59.345^{\prime} \mathrm{W}$ & \\
\hline 98 & POS536_68-1 & E & 26.08 .2019 & 12:59 & Multicorer & $33^{\circ} 08.845^{\prime} \mathrm{N}$ & $038^{\circ} 59.384^{\prime} \mathrm{W}$ & $33^{\circ} 08.772^{\prime} \mathrm{N}$ & $038^{\circ} 59.365^{\prime} \mathrm{W}$ & fail \\
\hline 99 & POS536_69-1 & $\mathrm{E}$ & 26.08 .2019 & $14: 15$ & CTD & $33^{\circ} 09.006^{\prime} \mathrm{N}$ & $039^{\circ} 00.022^{\prime} \mathrm{W}$ & $33^{\circ} 08.968^{\prime} \mathrm{N}$ & $039^{\circ} 00.031^{\prime} \mathrm{W}$ & \\
\hline 100 & POS536_0_Underway-2 & E-F & 26.08 .2019 & $15: 30$ & Monitoring & $3309.649 \mathrm{~N}$ & $39^{\circ} 03.292^{\prime} \mathrm{W}$ & $33^{\circ} 10.295^{\prime} \mathrm{N}$ & $39^{\circ} 07.352^{\prime} \mathrm{W}$ & \\
\hline 101 & POS536_0_Underway-2 & E-F & 26.08 .2019 & 18:00 & Monitoring & $33^{\circ} 11.033^{\prime} \mathrm{N}$ & $39^{\circ} 13.381^{\prime} \mathrm{W}$ & $33^{\circ} 10.597 \mathrm{~N}$ & $39^{\circ} 17.845^{\prime} \mathrm{W}$ & \\
\hline 102 & $\mathrm{NA}$ & E-F & 26.08 .2019 & $18: 15$ & $\begin{array}{l}\text { Ocean Pack } \\
\end{array}$ & $33^{\circ} 08.968^{\prime} \mathrm{N}$ & $39^{\circ} 00.031^{\prime} \mathrm{W}$ & $\mathrm{NA}$ & NA & \\
\hline 103 & $\begin{array}{l}\text { POS536_0_Underway-2 } \\
\end{array}$ & E-F & 26.08 .2019 & 19:00 & Monitoring & $33^{\circ} 10.593^{\prime} \mathrm{N}$ & $39^{\circ} 17.845^{\prime} \mathrm{W}$ & $33^{\circ} 11.609^{\prime} \mathrm{N}$ & $39^{\circ} 21.560^{\prime} \mathrm{W}$ & \\
\hline 104 & POS536_70-1 & E-F & 27.08 .2019 & $8: 15$ & Sediment traps & $33^{\circ} 24.430^{\prime} \mathrm{N}$ & $040^{\circ} 13.849^{\prime} \mathrm{W}$ & $\mathrm{NA}$ & $\mathrm{NA}$ & \\
\hline 105 & POS536_0_Underway-2 & E-F & 27.08 .2019 & 12:00 & Monitoring & $33^{\circ} 33.097 \mathrm{~N}$ & $39^{\circ} 57.759^{\prime} \mathrm{W}$ & $33^{\circ} 36.625^{\prime} \mathrm{N}$ & $39^{\circ} 51.179^{\prime} \mathrm{W}$ & \\
\hline 106 & POS536_0_Underway-2 & E-F & 27.08 .2019 & 13:00 & Monitoring & $33^{\circ} 36.655^{\prime} \mathrm{N}$ & $39^{\circ} 51.123^{\prime} \mathrm{W}$ & $33^{\circ} 40.156^{\prime} \mathrm{N}$ & $39^{\circ} 44.617^{\prime} \mathrm{W}$ & \\
\hline 107 & POS536_0_Underway-2 & E-F & 27.08 .2019 & $15: 30$ & Monitoring & $33^{\circ} 45.482^{\prime} \mathrm{N}$ & $39^{\circ} 34.751^{\prime} \mathrm{W}$ & $33^{\circ} 48.963^{\prime} \mathrm{N}$ & $39^{\circ} 28.161^{\prime} \mathrm{W}$ & \\
\hline 108 & POS536_0_Underway-2 & E-F & 27.08 .2019 & $16: 30$ & Monitoring & $33^{\circ} 49.005^{\prime} \mathrm{N}$ & $39^{\circ} 28.085^{\prime} \mathrm{W}$ & $33^{\circ} 52.529^{\prime} \mathrm{N}$ & $39^{\circ} 21.509^{\prime} \mathrm{W}$ & \\
\hline 109 & POS536_0_Underway-2 & E-F & 27.08 .2019 & 18:00 & Monitoring & $33^{\circ} 54.313^{\prime} \mathrm{N}$ & $39^{\circ} 18.156^{\prime} \mathrm{W}$ & $33^{\circ} 57.698^{\prime} \mathrm{N}$ & $39^{\circ} 11.815^{\prime} \mathrm{W}$ & \\
\hline 110 & $\mathrm{NA}$ & E-F & 27.08 .2019 & $18: 15$ & $\begin{array}{l}\text { Ocean Pack } \\
\end{array}$ & $33^{\circ} 51.46^{\prime} \mathrm{N}$ & $39^{\circ} 23.51^{\prime} \mathrm{W}$ & $\mathrm{NA}$ & NA & \\
\hline 111 & POS536_0_Underway-2 & E-F & 27.08 .2019 & 19:00 & Monitoring & $33^{\circ} 57.727^{\prime} \mathrm{N}$ & $39^{\circ} 11.761^{\prime} \mathrm{W}$ & $34^{\circ} 01.146^{\prime} \mathrm{N}$ & $39^{\circ} 05.386^{\prime} \mathrm{W}$ & \\
\hline 112 & POS536_71-1 & $\mathrm{F}$ & 28.08 .2019 & $01: 48$ & CTD/INSITU Pumps/UWS & $34^{\circ} 19.999^{\prime} \mathrm{N}$ & $038^{\circ} 29.986^{\prime} \mathrm{W}$ & $34^{\circ} 18.769^{\prime} \mathrm{N}$ & $038^{\circ} 30.130^{\prime} \mathrm{W}$ & \\
\hline 113 & POS536_72-1 & $\mathrm{F}$ & 28.08 .2019 & 08:02 & Box Corer & $34^{\circ} 20.003^{\prime} \mathrm{N}$ & $038^{\circ} 30.446^{\prime} \mathrm{W}$ & $34^{\circ} 19.727^{\prime} \mathrm{N}$ & $038^{\circ} 30.251^{\prime} \mathrm{W}$ & \\
\hline 114 & POS536_73-1 & $\mathrm{F}$ & 28.08 .2019 & 10:07 & Box Corer & $34^{\circ} 19.652^{\prime} \mathrm{N}$ & $038^{\circ} 30.292^{\prime} \mathrm{W}$ & $34^{\circ} 19.465^{\prime} \mathrm{N}$ & $038^{\circ} 30.905^{\prime} \mathrm{W}$ & \\
\hline 115 & POS536_74-1 & $\mathrm{F}$ & 28.08 .2019 & 13:00 & Neuston Trawl & $34^{\circ} 20.106^{\prime} \mathrm{N}$ & $038^{\circ} 29.931^{\prime} \mathrm{W}$ & $34^{\circ} 18.473^{\prime} \mathrm{N}$ & $038^{\circ} 29.881^{\prime} \mathrm{W}$ & \\
\hline 116 & POS536_75-1 & $\mathrm{F}$ & 28.08 .2019 & 13:38 & Neuston Trawl & $34^{\circ} 18.739^{\prime} \mathrm{N}$ & $038^{\circ} 30.039^{\prime} \mathrm{W}$ & $34^{\circ} 16.886^{\prime} \mathrm{N}$ & $038^{\circ} 29.956^{\prime} \mathrm{W}$ & \\
\hline 117 & POS536_76-1 & $\mathrm{F}$ & 28.08 .2019 & $14: 19$ & Neuston Trawl & $34^{\circ} 17.456^{\prime} \mathrm{N}$ & $038^{\circ} 29.632^{\prime} \mathrm{W}$ & $34^{\circ} 15.855^{\prime} \mathrm{N}$ & $038^{\circ} 29.536^{\prime} \mathrm{W}$ & \\
\hline 118 & POS536_77-1 & F & 28.08 .2019 & $15: 28$ & WP2 Net & $34^{\circ} 20.026^{\prime} \mathrm{N}$ & $038^{\circ} 30.081^{\prime} \mathrm{W}$ & $34^{\circ} 19.934^{\prime} \mathrm{N}$ & $038^{\circ} 30.449^{\prime} \mathrm{W}$ & \\
\hline 119 & POS536_78-1 & F & 28.08 .2019 & $15: 53$ & WP2 Net & $34^{\circ} 19.910^{\prime} \mathrm{N}$ & $038^{\circ} 30.498^{\prime} \mathrm{W}$ & $34^{\circ} 19.650^{\prime} \mathrm{N}$ & $038^{\circ} 31.326^{\prime} \mathrm{W}$ & \\
\hline 120 & POS536_79-1 & $\mathrm{F}$ & $\begin{array}{l}28.08 .2019 \\
\end{array}$ & $16: 44$ & WP2 Net & $34^{\circ} 19.644^{\prime} \mathrm{N}$ & $038^{\circ} 31.402^{\prime} \mathrm{W}$ & $34^{\circ} 19.380^{\prime} \mathrm{N}$ & $038^{\circ} 32.662^{\prime} \mathrm{W}$ & \\
\hline 121 & $\mathrm{NA}$ & $\mathrm{F}$ & 28.08 .2019 & $18: 05$ & Ocean Pack & $34^{\circ} 19.38^{\prime} \mathrm{N}$ & $38^{\circ} 30.29^{\prime} \mathrm{W}$ & NA & NA & \\
\hline 122 & POS536_80-1 & F & 28.08 .2019 & $18: 29$ & Bongo Net & $34^{\circ} 20.145^{\prime} \mathrm{N}$ & $038^{\circ} 30.235^{\prime} \mathrm{W}$ & $34^{\circ} 18.996^{\prime} \mathrm{N}$ & $038^{\circ} 30.291^{\prime} \mathrm{W}$ & \\
\hline 123 & POS536_81-1 & F & 28.08 .2019 & 19:19 & Bongo Net & $34^{\circ} 19.983^{\prime} \mathrm{N}$ & $038^{\circ} 30.097^{\prime} \mathrm{W}$ & $34^{\circ} 18.399^{\prime} \mathrm{N}$ & $038^{\circ} 30.013^{\prime} \mathrm{W}$ & \\
\hline
\end{tabular}




\begin{tabular}{|c|c|c|c|c|c|c|c|c|c|c|}
\hline Station & DShip & Area & Date & Time & Gear & Latitude (start) & $\begin{array}{l}\begin{array}{l}\text { Longitude } \\
\text { (start) }\end{array} \\
\end{array}$ & $\begin{array}{l}\begin{array}{l}\text { Latitude } \\
\text { (end) }\end{array} \\
\end{array}$ & $\begin{array}{l}\begin{array}{l}\text { Longitude } \\
\text { (end) }\end{array} \\
\end{array}$ & Status/Comment \\
\hline 124 & POS536_82-1 & $\mathrm{F}$ & 28.08 .2019 & $20: 31$ & Bongo Net & $34^{\circ} 20.002^{\prime} \mathrm{N}$ & $038^{\circ} 30.055^{\prime} \mathrm{W}$ & $34^{\circ} 17.876^{\prime} \mathrm{N}$ & $038^{\circ} 30.010^{\prime} \mathrm{W}$ & \\
\hline 125 & POS536_83-1 & $\mathrm{F}$ & 28.08 .2019 & $22: 08$ & CTD & $34^{\circ} 20.037^{\prime} \mathrm{N}$ & $038^{\circ} 30.093^{\prime} \mathrm{W}$ & $34^{\circ} 19.831^{\prime} \mathrm{N}$ & $038^{\circ} 30.539^{\prime} \mathrm{W}$ & \\
\hline 126 & $\mathrm{NA}$ & & 29.08 .2019 & 08:00 & UWS & $\mathrm{NA}$ & NA & NA & NA & cancelled \\
\hline 127 & POS536_84-1 & G & 29.08 .2019 & 08:09 & Box Corer & $33^{\circ} 09.126^{\prime} \mathrm{N}$ & $037^{\circ} 59.980^{\prime} \mathrm{W}$ & $33^{\circ} 09.528^{\prime} \mathrm{N}$ & $037^{\circ} 59.708^{\prime} \mathrm{W}$ & fail \\
\hline 128 & POS536_85-1 & $\mathrm{G}$ & 29.08 .2019 & 12:00 & Box Corer & $33^{\circ} 09.149^{\prime} \mathrm{N}$ & $038^{\circ} 00.092^{\prime} \mathrm{W}$ & $33^{\circ} 08.974^{\prime} \mathrm{N}$ & $037^{\circ} 59.874^{\prime} \mathrm{W}$ & fail \\
\hline 129 & POS536_86-1 & $\mathrm{G}$ & 29.08 .2019 & 13:02 & Sediment Traps & $33^{\circ} 08.129^{\prime} \mathrm{N}$ & $037^{\circ} 59.765^{\prime} \mathrm{W}$ & $33^{\circ} 20.801^{\prime} \mathrm{N}$ & $037^{\circ} 20.931^{\prime} \mathrm{W}$ & \\
\hline 130 & POS536_87-1 & G & 29.08 .2019 & $14: 40$ & Neuston Trawl & $33^{\circ} 07.944^{\prime} \mathrm{N}$ & $037^{\circ} 59.550^{\prime} \mathrm{W}$ & $33^{\circ} 06.338^{\prime} \mathrm{N}$ & $037^{\circ} 59.227^{\prime} \mathrm{W}$ & \\
\hline 131 & POS536_88-1 & $\mathrm{G}$ & 29.08 .2019 & $15: 20$ & Neuston Trawl & $33^{\circ} 04.964^{\prime} \mathrm{N}$ & $037^{\circ} 59.046^{\prime} \mathrm{W}$ & $33^{\circ} 03.325^{\prime} \mathrm{N}$ & $037^{\circ} 58.811^{\prime} \mathrm{W}$ & \\
\hline 132 & POS536_89-1 & $\mathrm{G}$ & 29.08 .2019 & $15: 58$ & Neuston Trawl & $33^{\circ} 02.236^{\prime} \mathrm{N}$ & $037^{\circ} 58.635^{\prime} \mathrm{W}$ & $33^{\circ} 00.479^{\prime} \mathrm{N}$ & $037^{\circ} 58.040^{\prime} \mathrm{W}$ & \\
\hline 133 & NA & G & 29.08 .2019 & 18:05 & Ocean Pack & $33^{\circ} 00.479^{\prime} \mathrm{N}$ & $37^{\circ} 58.040^{\prime} \mathrm{W}$ & NA & NA & \\
\hline 134 & POS536_90-1 & G & 30.08 .2019 & 00:09 & WP2 Net & $33^{\circ} 09.050^{\prime} \mathrm{N}$ & $037^{\circ} 59.881^{\prime} \mathrm{W}$ & $33^{\circ} 09.034^{\prime} \mathrm{N}$ & $037^{\circ} 59.866^{\prime} \mathrm{W}$ & \\
\hline 135 & POS536_91-1 & $\mathrm{G}$ & 30.08 .2019 & $00: 35$ & WP Net & $33^{\circ} 09.035^{\prime} \mathrm{N}$ & $037^{\circ} 59.868^{\prime} \mathrm{W}$ & $33^{\circ} 08.983^{\prime} \mathrm{N}$ & $037^{\circ} 59.854^{\prime} \mathrm{W}$ & \\
\hline 136 & POS536_92-1 & $\mathrm{G}$ & 30.08 .2019 & $01: 19$ & WP2 Net & $33^{\circ} 08.979^{\prime} \mathrm{N}$ & $037^{\circ} 59.857^{\prime} \mathrm{W}$ & $33^{\circ} 08.900^{\prime} \mathrm{N}$ & $037^{\circ} 59.784^{\prime} \mathrm{W}$ & \\
\hline 137 & POS536_93-1 & G & 30.08 .2019 & $02: 34$ & Bongo Net & $33^{\circ} 08.826^{\prime} \mathrm{N}$ & $037^{\circ} 59.724^{\prime} \mathrm{W}$ & $33^{\circ} 09.586^{\prime} \mathrm{N}$ & $037^{\circ} 59.392^{\prime} \mathrm{W}$ & \\
\hline 138 & POS536_94-1 & $\mathrm{G}$ & 30.08 .2019 & 03:32 & Bongo Net & $33^{\circ} 09.277^{\prime} \mathrm{N}$ & $037^{\circ} 59.872^{\prime} \mathrm{W}$ & $33^{\circ} 10.990^{\prime} \mathrm{N}$ & $038^{\circ} 00.072^{\prime} \mathrm{W}$ & \\
\hline 139 & POS536_95-1 & G & 30.08 .2019 & $04: 48$ & Bongo Net & $33^{\circ} 09.086^{\prime} \mathrm{N}$ & $037^{\circ} 59.989^{\prime} \mathrm{W}$ & $33^{\circ} 11.720^{\prime} \mathrm{N}$ & $037^{\circ} 59.370^{\prime} \mathrm{W}$ & \\
\hline 140 & $\begin{array}{l}\text { POS536_96-1 } \\
\end{array}$ & G & 30.08 .2019 & $06: 36$ & CTD & $33^{\circ} 09.073^{\prime} \mathrm{N}$ & $037^{\circ} 59.935^{\prime} \mathrm{W}$ & $33^{\circ} 09.066^{\prime} \mathrm{N}$ & $037^{\circ} 59.975^{\prime} \mathrm{W}$ & \\
\hline 141 & POS536_0_Underway-2 & G-H & 30.08 .2019 & 08:00 & Monitoring & $33^{\circ} 12.4200^{\prime} \mathrm{N}$ & $37^{\circ} 58.856^{\prime} \mathrm{W}$ & $33^{\circ} 21.374^{\prime} \mathrm{N}$ & $37^{\circ} 55.905^{\prime} \mathrm{W}$ & \\
\hline 142 & $\begin{array}{l}\text { POS536_0_Underway-2 } \\
\end{array}$ & G-H & 30.08 .2019 & 09:00 & Monitoring & $33^{\circ} 21.4488^{\prime} \mathrm{N}$ & $037^{\circ} 55.880^{\prime} \mathrm{W}$ & $33^{\circ} 30.440^{\prime} \mathrm{N}$ & $37^{\circ} 52.905^{\prime} \mathrm{W}$ & \\
\hline 143 & POS536_0_Underway-2 & G-H & 30.08 .2019 & 12:00 & Monitoring & $33^{\circ} 48.565^{\prime} \mathrm{N}$ & $37^{\circ} 46.877^{\prime} \mathrm{W}$ & $33^{\circ} 57.078^{\prime} \mathrm{N}$ & $37^{\circ} 44.039^{\prime} \mathrm{W}$ & \\
\hline 144 & POS536_0_Underway-2 & G-H & 30.08 .2019 & 13:00 & Monitoring & $33^{\circ} 57.155^{\prime} \mathrm{N}$ & $037^{\circ} 44.013^{\prime} \mathrm{W}$ & $34^{\circ} 05.617^{\prime} \mathrm{N}$ & $037^{\circ} 41.184^{\prime} \mathrm{W}$ & \\
\hline 145 & POS536_0_Underway-2 & G-H & 30.08 .2019 & $15: 30$ & Monitoring & $34^{\circ} 18.948^{\prime} \mathrm{N}$ & $37^{\circ} 36.730^{\prime} \mathrm{W}$ & $34^{\circ} 27.345^{\prime} \mathrm{N}$ & $037^{\circ} 33.920^{\prime} \mathrm{W}$ & \\
\hline 146 & $\begin{array}{l}\text { POS536_0_Underway-2 } \\
\end{array}$ & G-H & 30.08 .2019 & $16: 30$ & Monitoring & $34^{\circ} 27.368^{\prime} \mathrm{N}$ & $37^{\circ} 33.911^{\prime} \mathrm{W}$ & $34^{\circ} 35.719^{\prime} \mathrm{N}$ & $37^{\circ} 31.111^{\prime} \mathrm{W}$ & \\
\hline 147 & $\mathrm{NA}$ & $\mathrm{H}$ & 30.08 .2019 & 18:00 & UWS & $\mathrm{NA}$ & NA & $\mathrm{NA}$ & $\mathrm{NA}$ & cancelled \\
\hline 148 & $\mathrm{NA}$ & $\mathrm{H}$ & 30.08 .2019 & $18: 15$ & Ocean Pack & $34^{\circ} 38.939^{\prime} \mathrm{N}$ & $37^{\circ} 30.134^{\prime} \mathrm{W}$ & $\mathrm{NA}$ & $\mathrm{NA}$ & \\
\hline 149 & POS536_97-1 & $\mathrm{H}$ & 30.08 .2019 & 18:18 & WP2 Net & $34^{\circ} 38.939^{\prime} \mathrm{N}$ & $037^{\circ} 30.134^{\prime} \mathrm{W}$ & $34^{\circ} 38.882^{\prime} \mathrm{N}$ & $037^{\circ} 30.217^{\prime} \mathrm{W}$ & \\
\hline 150 & POS536_98-1 & $\mathrm{H}$ & 30.08 .2019 & $18: 53$ & WP2 Net & $34^{\circ} 38.886^{\prime} \mathrm{N}$ & $037^{\circ} 30.223^{\prime} \mathrm{W}$ & $34^{\circ} 39.023^{\prime} \mathrm{N}$ & $037^{\circ} 30.337^{\prime} \mathrm{W}$ & \\
\hline 151 & POS536_99-1 & $\mathrm{H}$ & 30.08 .2019 & 19:51 & WP2 Net & $34^{\circ} 39.055^{\prime} \mathrm{N}$ & $037^{\circ} 30.262^{\prime} \mathrm{W}$ & $34^{\circ} 39.323^{\prime} \mathrm{N}$ & $037^{\circ} 31.525^{\prime} \mathrm{W}$ & \\
\hline 152 & POS536_100-1 & $\mathrm{H}$ & 30.08 .2019 & $21: 21$ & Bongo Net & $34^{\circ} 39.407^{\prime} \mathrm{N}$ & $037^{\circ} 31.874^{\prime} \mathrm{W}$ & $34^{\circ} 39.567^{\prime} \mathrm{N}$ & $037^{\circ} 33.887^{\prime} \mathrm{W}$ & \\
\hline 153 & POS536_101-1 & $\mathrm{H}$ & 30.08 .2019 & $22: 30$ & Bongo Net & $34^{\circ} 39.374^{\prime} \mathrm{N}$ & $037^{\circ} 31.084^{\prime} \mathrm{W}$ & $34^{\circ} 39.750^{\prime} \mathrm{N}$ & $037^{\circ} 33.355^{\prime} \mathrm{W}$ & \\
\hline 154 & POS536_102-1 & $\mathrm{H}$ & 30.08 .2019 & $23: 49$ & Bongo Net & $34^{\circ} 39.286^{\prime} \mathrm{N}$ & $037^{\circ} 31.009^{\prime} \mathrm{W}$ & $34^{\circ} 39.875^{\prime} \mathrm{N}$ & $037^{\circ} 34.061^{\prime} \mathrm{W}$ & \\
\hline 155 & POS536_103-1 & $\mathrm{H}$ & 31.08 .2019 & $01: 47$ & CTD/INSITU Pumps & $34^{\circ} 39.022^{\prime} \mathrm{N}$ & $037^{\circ} 29.965^{\prime} \mathrm{W}$ & $34^{\circ} 39.369^{\prime} \mathrm{N}$ & $037^{\circ} 33.936^{\prime} \mathrm{W}$ & \\
\hline
\end{tabular}




\begin{tabular}{|c|c|c|c|c|c|c|c|c|c|c|}
\hline Station & DShip & Area & Date & Time & Gear & Latitude (start) & $\begin{array}{l}\begin{array}{l}\text { Longitude } \\
\text { (start) }\end{array} \\
\end{array}$ & $\begin{array}{l}\begin{array}{l}\text { Latitude } \\
\text { (end) }\end{array} \\
\end{array}$ & $\begin{array}{l}\begin{array}{l}\text { Longitude } \\
\text { (end) }\end{array} \\
\end{array}$ & Status/Comment \\
\hline 156 & POS536_104-1 & $\mathrm{H}$ & 31.08 .2019 & 08:00 & Box Corer & $34^{\circ} 39.051^{\prime} \mathrm{N}$ & $037^{\circ} 30.062^{\prime} \mathrm{W}$ & $34^{\circ} 39.035^{\prime} \mathrm{N}$ & $037^{\circ} 30.520^{\prime} \mathrm{W}$ & fail \\
\hline 157 & POS536_105-1 & $\mathrm{H}$ & 31.08 .2019 & $10: 13$ & Box Corer & $34^{\circ} 33.419^{\prime} \mathrm{N}$ & $037^{\circ} 31.890^{\prime} \mathrm{W}$ & $34^{\circ} 33.134^{\prime} \mathrm{N}$ & $037^{\circ} 32.674^{\prime} \mathrm{W}$ & \\
\hline 158 & POS536_106-1 & $\mathrm{H}$ & 31.08 .2019 & 13:00 & Neuston Trawl & $34^{\circ} 33.939^{\prime} \mathrm{N}$ & $037^{\circ} 33.988^{\prime} \mathrm{W}$ & $34^{\circ} 35.406^{\prime} \mathrm{N}$ & $037^{\circ} 34.818^{\prime} \mathrm{W}$ & \\
\hline 159 & POS536_107-1 & $\mathrm{H}$ & 31.08 .2019 & 13:39 & Neuston Trawl & $34^{\circ} 35.127^{\prime} \mathrm{N}$ & $037^{\circ} 34.108^{\prime} \mathrm{W}$ & $34^{\circ} 36.621^{\prime} \mathrm{N}$ & $037^{\circ} 34.956^{\prime} \mathrm{W}$ & \\
\hline 160 & POS536_108-1 & $\mathrm{H}$ & 31.08 .2019 & 14:18 & Neuston Trawl & $34^{\circ} 36.097^{\prime} \mathrm{N}$ & $037^{\circ} 34.247^{\prime} \mathrm{W}$ & $34^{\circ} 37.469^{\prime} \mathrm{N}$ & $037^{\circ} 35.125^{\prime} \mathrm{W}$ & \\
\hline 161 & POS536_109-1 & $\mathrm{H}$ & 31.08 .2019 & $15: 32$ & CTD & $34^{\circ} 38.967^{\prime} \mathrm{N}$ & $037^{\circ} 30.019^{\prime} \mathrm{W}$ & $34^{\circ} 38.755^{\prime} \mathrm{N}$ & $037^{\circ} 30.174^{\prime} \mathrm{W}$ & \\
\hline 162 & POS536_0_Underway-2 & H-I & 31.08 .2019 & 18:00 & Monitoring & $34^{\circ} 24.194^{\prime} \mathrm{N}$ & $37^{\circ} 25.025^{\prime} \mathrm{W}$ & $34^{\circ} 15.770^{\prime} \mathrm{N}$ & $37^{\circ} 22.207^{\prime} \mathrm{W}$ & \\
\hline 163 & NA & H-I & 31.08 .2019 & $18: 34$ & $\begin{array}{l}\text { Ocean Pack } \\
\end{array}$ & $341919 \mathrm{~N}$ & $37^{\circ} 23.34^{\prime} \mathrm{W}$ & $\mathrm{NA}$ & $\mathrm{NA}$ & \\
\hline 164 & POS536_0_Underway-2 & H-I & 31.08 .2019 & 19:00 & Monitoring & $34^{\circ} 15.707^{\prime} \mathrm{N}$ & $37^{\circ} 22.187^{\prime} \mathrm{W}$ & $34^{\circ} 07.284^{\prime} \mathrm{N}$ & $37^{\circ} 19.370^{\prime} \mathrm{W}$ & \\
\hline 165 & POS536_0_Underway-2 & H-I & 31.08 .2019 & 20:00 & Monitoring & $34^{\circ} 07.196^{\prime} \mathrm{N}$ & $37^{\circ} 19.341^{\prime} \mathrm{W}$ & $33^{\circ} 58.850^{\prime} \mathrm{N}$ & $37^{\circ} 16.551^{\prime} \mathrm{W}$ & \\
\hline 166 & NA & I & 01.09 .2019 & 02:00 & UWS & $\mathrm{NA}$ & NA & $\mathrm{NA}$ & $\mathrm{NA}$ & \\
\hline 167 & POS536_110-1 & $\mathrm{I}$ & 01.09 .2019 & 03:06 & WP2 Net & $33^{\circ} 09.000^{\prime} \mathrm{N}$ & $036^{\circ} 59.962^{\prime} \mathrm{W}$ & $33^{\circ} 08.946^{\prime} \mathrm{N}$ & $036^{\circ} 59.949^{\prime} \mathrm{W}$ & \\
\hline 168 & POS536_111-1 & I & 01.09 .2019 & 03:30 & WP2 Net & $33^{\circ} 08.933^{\prime} \mathrm{N}$ & $036^{\circ} 59.938^{\prime} \mathrm{W}$ & $33^{\circ} 08.919^{\prime} \mathrm{N}$ & $036^{\circ} 59.993^{\prime} \mathrm{W}$ & \\
\hline 169 & POS536_112-1 & I & 01.09 .2019 & $04: 20$ & WP2 Net & $33^{\circ} 08.921^{\prime} \mathrm{N}$ & $037^{\circ} 00.001^{\prime} \mathrm{W}$ & $33^{\circ} 08.943^{\prime} \mathrm{N}$ & $037^{\circ} 00.547^{\prime} \mathrm{W}$ & \\
\hline 170 & POS536_113-1 & I & 01.09 .2019 & $05: 42$ & Neuston Trawl & $33^{\circ} 08.943^{\prime} \mathrm{N}$ & $037^{\circ} 00.766^{\prime} \mathrm{W}$ & $33^{\circ} 08.659^{\prime} \mathrm{N}$ & $037^{\circ} 01.601^{\prime} \mathrm{W}$ & \\
\hline 171 & POS536_114-1 & I & 01.09 .2019 & $06: 11$ & Neuston Trawl & $33^{\circ} 08.686^{\prime} \mathrm{N}$ & $037^{\circ} 02.161^{\prime} \mathrm{W}$ & $33^{\circ} 09.534^{\prime} \mathrm{N}$ & $037^{\circ} 02.046^{\prime} \mathrm{W}$ & \\
\hline 172 & $\begin{array}{l}\text { POS536_115-1 } \\
\end{array}$ & I & 01.09 .2019 & $06: 36$ & Neuston Trawl & $33^{\circ} 10.288^{\prime} \mathrm{N}$ & $037^{\circ} 01.954^{\prime} \mathrm{W}$ & $33^{\circ} 11.101^{\prime} \mathrm{N}$ & $037^{\circ} 01.897^{\prime} \mathrm{W}$ & \\
\hline 173 & $\begin{array}{l}\text { POS536_116-1 } \\
\end{array}$ & I & 01.09 .2019 & 08:03 & Box Corer & $33^{\circ} 09.008^{\prime} \mathrm{N}$ & $036^{\circ} 59.987^{\prime} \mathrm{W}$ & $33^{\circ} 09.017^{\prime} \mathrm{N}$ & $036^{\circ} 59.906^{\prime} \mathrm{W}$ & fail \\
\hline 174 & POS536_117-1 & I & 01.09 .2019 & 09:40 & Box Corer & $33^{\circ} 09.007^{\prime} \mathrm{N}$ & $036^{\circ} 59.896^{\prime} \mathrm{W}$ & $33^{\circ} 09.090^{\prime} \mathrm{N}$ & $036^{\circ} 59.920^{\prime} \mathrm{W}$ & fail \\
\hline 175 & POS536_118-1 & I & 01.09 .2019 & 13:07 & Bongo Net & $33^{\circ} 08.428^{\prime} \mathrm{N}$ & $036^{\circ} 59.402^{\prime} \mathrm{W}$ & $33^{\circ} 07.320^{\prime} \mathrm{N}$ & $036^{\circ} 59.793^{\prime} \mathrm{W}$ & \\
\hline 176 & $\begin{array}{l}\text { POS536_119-1 } \\
\end{array}$ & $\mathrm{I}$ & 01.09 .2019 & $14: 10$ & Bongo Net & $33^{\circ} 08.999^{\prime} \mathrm{N}$ & $037^{\circ} 00.064^{\prime} \mathrm{W}$ & $33^{\circ} 07.572^{\prime} \mathrm{N}$ & $037^{\circ} 00.988^{\prime} \mathrm{W}$ & \\
\hline 177 & POS536_120-1 & I & 01.09 .2019 & $15: 26$ & Bongo Net & $33^{\circ} 09.037^{\prime} \mathrm{N}$ & $037^{\circ} 00.030^{\prime} \mathrm{W}$ & $33^{\circ} 06.896^{\prime} \mathrm{N}$ & $037^{\circ} 01.401^{\prime} \mathrm{W}$ & \\
\hline 178 & POS536_121-1 & I & 01.09 .2019 & 17:08 & CTD & $33^{\circ} 09.026^{\prime} \mathrm{N}$ & $037^{\circ} 00.036^{\prime} \mathrm{W}$ & $33^{\circ} 08.917^{\prime} \mathrm{N}$ & $037^{\circ} 00.263^{\prime} \mathrm{W}$ & \\
\hline 179 & POS536_0_Underway-2 & I-J & 01.09 .2019 & 18:00 & Monitoring & $33^{\circ} 08.913^{\prime} \mathrm{N}$ & $37^{\circ} 00.265^{\prime} \mathrm{W}$ & $33^{\circ} 14.966^{\prime} \mathrm{N}$ & $37^{\circ} 00.070^{\prime} \mathrm{W}$ & \\
\hline 180 & $\mathrm{NA}$ & I-J & 01.09 .2019 & 18:00 & $\begin{array}{l}\text { Ocean Pack } \\
\end{array}$ & $33^{\circ} 08.92^{2} \mathrm{~N}$ & $37^{\circ} 00.26^{\prime} \mathrm{W}$ & NA & $\mathrm{NA}$ & \\
\hline 181 & POS536_0_Underway-2 & I-J & 01.09 .2019 & 19:00 & Monitoring & $33^{\circ} 15.029^{\prime} \mathrm{N}$ & $37^{\circ} 00.070^{\prime} \mathrm{W}$ & $33^{\circ} 21.646^{\prime} \mathrm{N}$ & $37^{\circ} 00.150^{\prime} \mathrm{W}$ & \\
\hline 182 & POS536_0_Underway-2 & I-J & 01.09 .2019 & $20: 00$ & Monitoring & $33^{\circ} 21.691^{\prime} \mathrm{N}$ & $37^{\circ} 00.151^{\prime} \mathrm{W}$ & $33^{\circ} 28.511^{\prime} \mathrm{N}$ & $37^{\circ} 00.222^{\prime} \mathrm{W}$ & \\
\hline 183 & $\mathrm{NA}$ & I-J & 02.09 .2019 & 04:00 & UWS & $\mathrm{NA}$ & NA & NA & $\mathrm{NA}$ & cancelled \\
\hline 184 & POS536_122-1 & $\mathrm{J}$ & $\begin{array}{l}02.09 .2019 \\
\end{array}$ & 04:04 & WP2 Net & $34^{\circ} 14.743^{\prime} \mathrm{N}$ & $037^{\circ} 00.802^{\prime} \mathrm{W}$ & $34^{\circ} 14.706^{\prime} \mathrm{N}$ & $037^{\circ} 00.910^{\prime} \mathrm{W}$ & \\
\hline 185 & POS536_123-1 & $J$ & 02.09 .2019 & $04: 31$ & WP2 Net & $34^{\circ} 14.699^{\prime} \mathrm{N}$ & $037^{\circ} 00.918^{\prime} \mathrm{W}$ & $34^{\circ} 14.573^{\prime} \mathrm{N}$ & $037^{\circ} 01.069^{\prime} \mathrm{W}$ & \\
\hline 186 & POS536_124-1 & $J$ & $\begin{array}{l}02.09 .2019 \\
\end{array}$ & $05: 23$ & WP2 Net & $34^{\circ} 14.565^{\prime} \mathrm{N}$ & $037^{\circ} 01.095^{\prime} \mathrm{W}$ & $34^{\circ} 14.381^{\prime} \mathrm{N}$ & $037^{\circ} 01.643^{\prime} \mathrm{W}$ & \\
\hline 187 & POS536_125-1 & $J$ & 02.09 .2019 & 08:00 & Multicorer & $34^{\circ} 14.774^{\prime} \mathrm{N}$ & $037^{\circ} 00.825^{\prime} \mathrm{W}$ & $34^{\circ} 14.631^{\prime} \mathrm{N}$ & $037^{\circ} 01.081^{\prime} \mathrm{W}$ & fail \\
\hline
\end{tabular}




\begin{tabular}{|c|c|c|c|c|c|c|c|c|c|c|}
\hline Station & DShip & Area & Date & Time & Gear & Latitude (start) & $\begin{array}{l}\begin{array}{l}\text { Longitude } \\
\text { (start) }\end{array}\end{array}$ & $\begin{array}{l}\begin{array}{l}\text { Latitude } \\
\text { (end) }\end{array} \\
\text { (a) }\end{array}$ & $\begin{array}{l}\begin{array}{l}\text { Longitude } \\
\text { (end) }\end{array} \\
\text { (a) }\end{array}$ & Status/Comment \\
\hline 188 & POS536_126-1 & $J$ & 02.09 .2019 & $08: 48$ & Multicorer & $34^{\circ} 14.620^{\prime} \mathrm{N}$ & $037^{\circ} 01.105^{\prime} \mathrm{W}$ & $34^{\circ} 14.644^{\prime} \mathrm{N}$ & $037^{\circ} 01.117^{\prime} \mathrm{W}$ & fail \\
\hline 189 & POS536_127-1 & $\mathrm{J}$ & 02.09 .2019 & 09:40 & Bongo Net & $34^{\circ} 14.595^{\prime} \mathrm{N}$ & $037^{\circ} 01.106^{\prime} \mathrm{W}$ & $34^{\circ} 14.670^{\prime} \mathrm{N}$ & $037^{\circ} 02.301^{\prime} \mathrm{W}$ & \\
\hline 190 & POS536_128-1 & $\mathrm{J}$ & 02.09 .2019 & $10: 35$ & Bongo Net & $34^{\circ} 14.891^{\prime} \mathrm{N}$ & $037^{\circ} 00.967^{\prime} \mathrm{W}$ & $34^{\circ} 15.370^{\prime} \mathrm{N}$ & $037^{\circ} 02.940^{\prime} \mathrm{W}$ & \\
\hline 191 & POS536_129-1 & $J$ & 02.09 .2019 & $11: 49$ & Bongo Net & $34^{\circ} 14.961^{\prime} \mathrm{N}$ & $037^{\circ} 00.654^{\prime} \mathrm{W}$ & $34^{\circ} 15.092^{\prime} \mathrm{N}$ & $037^{\circ} 03.726^{\prime} \mathrm{W}$ & \\
\hline 192 & POS536_130-1 & $\mathrm{J}$ & 02.09 .2019 & 13:33 & Neuston Trawl & $34^{\circ} 15.032^{\prime} \mathrm{N}$ & $037^{\circ} 02.846^{\prime} \mathrm{W}$ & $34^{\circ} 14.629^{\prime} \mathrm{N}$ & $037^{\circ} 04.735^{\prime} \mathrm{W}$ & \\
\hline 193 & POS536_131-1 & $J$ & 02.09 .2019 & $14: 13$ & Neuston Trawl & $34^{\circ} 14.586^{\prime} \mathrm{N}$ & $037^{\circ} 04.179^{\prime} \mathrm{W}$ & $34^{\circ} 14.084^{\prime} \mathrm{N}$ & $037^{\circ} 05.998^{\prime} \mathrm{W}$ & \\
\hline 194 & POS536_132-1 & $\mathrm{J}$ & 02.09 .2019 & $14: 53$ & Neuston Trawl & $34^{\circ} 14.116^{\prime} \mathrm{N}$ & $037^{\circ} 05.377^{\prime} \mathrm{W}$ & $34^{\circ} 13.656^{\prime} \mathrm{N}$ & $037^{\circ} 07.276^{\prime} \mathrm{W}$ & \\
\hline 195 & $\begin{array}{l}\text { POS536_133-1 } \\
\end{array}$ & $\mathrm{J}$ & 02.09 .2019 & $16: 25$ & CTD & $34^{\circ} 14.703^{\prime} \mathrm{N}$ & $037^{\circ} 00.786^{\prime} \mathrm{W}$ & $34^{\circ} 12.681^{\prime} \mathrm{N}$ & $037^{\circ} 10.490^{\prime} \mathrm{W}$ & \\
\hline 196 & NA & $\mathrm{J}$ & 02.09 .2019 & 18:00 & Ocean Pack & $34^{\circ} 14.528^{\prime} \mathrm{N}$ & $37^{\circ} 01.409^{\prime} \mathrm{W}$ & NA & NA & \\
\hline 197 & POS536_134-1 & $\mathrm{J}-\mathrm{K}$ & 03.09 .2019 & $8: 22$ & Sediment Traps & $33^{\circ} 20.801^{\prime} \mathrm{N}$ & $037^{\circ} 20.931^{\prime} \mathrm{W}$ & NA & NA & \\
\hline 198 & POS536_0_Underway-2 & $\mathrm{J}-\mathrm{K}$ & 03.09 .2019 & 12:00 & Monitoring & $33^{\circ} 21.033^{\prime} \mathrm{N}$ & $36^{\circ} 57.621^{\prime} \mathrm{W}$ & $33^{\circ} 21.093^{\prime} \mathrm{N}$ & $36^{\circ} 48.641^{\prime} \mathrm{W}$ & \\
\hline 200 & POS536_0_Underway-2 & $\mathrm{J}-\mathrm{K}$ & 03.09 .2019 & 13:00 & Monitoring & $33^{\circ} 21.093^{\prime} \mathrm{N}$ & $36^{\circ} 48.576^{\prime} \mathrm{W}$ & $33^{\circ} 21.173^{\prime} \mathrm{N}$ & $36^{\circ} 39.318^{\prime} \mathrm{W}$ & \\
\hline 201 & POS536_0_Underway-2 & $\mathrm{J}-\mathrm{K}$ & 03.09 .2019 & $15: 30$ & Monitoring & $33^{\circ} 21.281^{\prime} \mathrm{N}$ & $36^{\circ} 25.226^{\prime} \mathrm{W}$ & $33^{\circ} 21.357^{\prime} \mathrm{N}$ & $36^{\circ} 16.026^{\prime} \mathrm{W}$ & \\
\hline 202 & POS536_0_Underway-2 & $\mathrm{J}-\mathrm{K}$ & 03.09 .2019 & $16: 30$ & Monitoring & $33^{\circ} 21.357^{\prime} \mathrm{N}$ & $36^{\circ} 15.966^{\prime} \mathrm{W}$ & $33^{\circ} 20.937^{\prime} \mathrm{N}$ & $36^{\circ} 05.870^{\prime} \mathrm{W}$ & \\
\hline 203 & POS536_0_Underway-2 & $\mathrm{J}-\mathrm{K}$ & 03.09 .2019 & 18:00 & Monitoring & $33^{\circ} 20.557^{\prime} \mathrm{N}$ & $36^{\circ} 01.258^{\prime} \mathrm{W}$ & $33^{\circ} 19.734^{\prime} \mathrm{N}$ & $35^{\circ} 51.202^{\prime} \mathrm{W}$ & \\
\hline 204 & $\mathrm{NA}$ & $\mathrm{J}-\mathrm{K}$ & 03.09 .2019 & $18: 15$ & Ocean Pack & $33^{\circ} 20.557^{\prime} \mathrm{N}$ & $036^{\circ} 01.258^{\prime} \mathrm{W}$ & $\mathrm{NA}$ & $N A$ & \\
\hline 205 & POS536_0_Underway-2 & $\mathrm{J}-\mathrm{K}$ & 03.09 .2019 & 19:00 & Monitoring & $33^{\circ} 19.726^{\prime} \mathrm{N}$ & $35^{\circ} 51.103^{\prime} \mathrm{W}$ & $33^{\circ} 18.902^{\prime} \mathrm{N}$ & $35^{\circ} 40.989^{\prime} \mathrm{W}$ & \\
\hline 206 & POS536_0_Underway-2 & $\mathrm{J}-\mathrm{K}$ & 03.09 .2019 & 20:00 & Monitoring & $\mathrm{NA}$ & $\mathrm{NA}$ & $\mathrm{NA}$ & NA & fail \\
\hline 208 & NA & $\mathrm{K}$ & 04.09 .2019 & $08: 00$ & UWS & NA & NA & NA & NA & cancelled \\
\hline 209 & POS536_135-1 & $\mathrm{K}$ & 04.09 .2019 & 08:02 & Bongo Net & $33^{\circ} 09.898^{\prime} \mathrm{N}$ & $033^{\circ} 52.552^{\prime} \mathrm{W}$ & $33^{\circ} 08.659^{\prime} \mathrm{N}$ & $033^{\circ} 52.757^{\prime} \mathrm{W}$ & \\
\hline 210 & $\begin{array}{l}\text { POS536_136-1 } \\
\end{array}$ & $\mathrm{K}$ & 04.09 .2019 & $08: 59$ & Bongo Net & $33^{\circ} 09.958^{\prime} \mathrm{N}$ & $033^{\circ} 52.583^{\prime} \mathrm{W}$ & $33^{\circ} 08.494^{\prime} \mathrm{N}$ & $033^{\circ} 53.080^{\prime} \mathrm{W}$ & \\
\hline 211 & POS536_137-1 & $\mathrm{K}$ & 04.09 .2019 & 10:09 & Bongo Net & $33^{\circ} 09.951^{\prime} \mathrm{N}$ & $033^{\circ} 52.391^{\prime} \mathrm{W}$ & $33^{\circ} 07.650^{\prime} \mathrm{N}$ & $033^{\circ} 52.531^{\prime} \mathrm{W}$ & \\
\hline 212 & $\begin{array}{l}\text { POS536_138-1 } \\
\end{array}$ & $\mathrm{K}$ & 04.09 .2019 & $11: 55$ & WP2 Net & $33^{\circ} 10.069^{\prime} \mathrm{N}$ & $033^{\circ} 52.525^{\prime} \mathrm{W}$ & $33^{\circ} 10.023^{\prime} \mathrm{N}$ & $033^{\circ} 52.536^{\prime} \mathrm{W}$ & \\
\hline 213 & $\begin{array}{l}\text { POS536_139-1 } \\
\end{array}$ & $\mathrm{K}$ & 04.09 .2019 & $12: 21$ & WP2 Net & $33^{\circ} 10.024^{\prime} \mathrm{N}$ & $033^{\circ} 52.538^{\prime} \mathrm{W}$ & $33^{\circ} 09.931^{\prime} \mathrm{N}$ & $033^{\circ} 52.508^{\prime} \mathrm{W}$ & \\
\hline 214 & $\begin{array}{l}\text { POS536_140-1 } \\
\end{array}$ & $\mathrm{K}$ & 04.09 .2019 & 13:15 & WP2 Net & $33^{\circ} 09.912^{\prime} \mathrm{N}$ & $033^{\circ} 52.510^{\prime} \mathrm{W}$ & $33^{\circ} 09.704^{\prime} \mathrm{N}$ & $033^{\circ} 52.465^{\prime} \mathrm{W}$ & \\
\hline 215 & $\begin{array}{l}\text { POS536_141-1 } \\
\end{array}$ & $\mathrm{K}$ & 04.09 .2019 & $14: 46$ & Neuston Trawl & $33^{\circ} 09.342^{\prime} \mathrm{N}$ & $033^{\circ} 52.645^{\prime} \mathrm{W}$ & $33^{\circ} 08.609^{\prime} \mathrm{N}$ & $033^{\circ} 52.996^{\prime} \mathrm{W}$ & \\
\hline 216 & $\begin{array}{l}\text { POS536_142-1 } \\
\end{array}$ & $\mathrm{K}$ & 04.09 .2019 & 15:08 & Neuston Trawl & $33^{\circ} 08.417^{\prime} \mathrm{N}$ & $033^{\circ} 53.058^{\prime} \mathrm{W}$ & $33^{\circ} 07.608^{\prime} \mathrm{N}$ & $033^{\circ} 53.422^{\prime} \mathrm{W}$ & \\
\hline 217 & POS536_143-1 & $\mathrm{K}$ & 04.09 .2019 & $15: 34$ & Neuston Trawl & $33^{\circ} 07.543^{\prime} \mathrm{N}$ & $033^{\circ} 53.676^{\prime} \mathrm{W}$ & $33^{\circ} 08.369^{\prime} \mathrm{N}$ & $033^{\circ} 53.349^{\prime} \mathrm{W}$ & \\
\hline 218 & POS536_144-1 & $\mathrm{K}$ & 04.09 .2019 & 16:09 & CTD/INSITU Pumps & $33^{\circ} 10.022^{\prime} \mathrm{N}$ & $033^{\circ} 52.415^{\prime} \mathrm{W}$ & $33^{\circ} 09.643^{\prime} \mathrm{N}$ & $033^{\circ} 49.178^{\prime} \mathrm{W}$ & \\
\hline 219 & $\mathrm{NA}$ & $\mathrm{K}$ & 04.09 .2019 & $18: 15$ & $\begin{array}{l}\text { Ocean Pack } \\
\end{array}$ & $33^{\circ} 09.916^{\prime} \mathrm{N}$ & $033^{\circ} 52.464^{\prime} \mathrm{W}$ & $\mathrm{NA}$ & NA & \\
\hline 220 & POS536_145-1 & $\mathrm{K}$ & 04.09 .2019 & $22: 11$ & Neuston Trawl & $33^{\circ} 09.908^{\prime} \mathrm{N}$ & $033^{\circ} 28.410^{\prime} \mathrm{W}$ & $33^{\circ} 09.535^{\prime} \mathrm{N}$ & $033^{\circ} 27.439^{\prime} \mathrm{W}$ & \\
\hline 221 & $\begin{array}{l}\text { POS536_146-1 } \\
\end{array}$ & $\mathrm{K}$ & 04.09 .2019 & $22: 35$ & Neuston Trawl & $33^{\circ} 09.286^{\prime} \mathrm{N}$ & $033^{\circ} 26.872^{\prime} \mathrm{W}$ & $33^{\circ} 08.978^{\prime} \mathrm{N}$ & $033^{\circ} 26.021^{\prime} \mathrm{W}$ & \\
\hline
\end{tabular}




\begin{tabular}{|c|c|c|c|c|c|c|c|c|c|c|}
\hline Station & DShip & Area & Date & Time & Gear & Latitude (start) & $\begin{array}{l}\begin{array}{l}\text { Longitude } \\
\text { (start) }\end{array}\end{array}$ & $\begin{array}{l}\begin{array}{l}\text { Latitude } \\
\text { (end) }\end{array}\end{array}$ & $\begin{array}{l}\begin{array}{l}\text { Longitude } \\
\text { (end) }\end{array}\end{array}$ & Status/Commen \\
\hline 222 & POS536_147-1 & $\mathrm{K}$ & 04.09 .2019 & 23:01 & Neuston Trawl & $33^{\circ} 08.620^{\prime} \mathrm{N}$ & $033^{\circ} 25.227^{\prime} \mathrm{W}$ & $33^{\circ} 08.435^{\prime} \mathrm{N}$ & $033^{\circ} 24.374^{\prime} \mathrm{W}$ & \\
\hline 223 & NA & Transit & 05.09 .2019 & 18:15 & $\begin{array}{l}\text { Ocean Pack } \\
\end{array}$ & $33^{\circ} 46.32^{\prime} \mathrm{N}$ & $30^{\circ} 19.08^{\prime} \mathrm{W}$ & NA & NA & \\
\hline 224 & NA & Transit & 06.09 .2019 & $10: 50$ & Ocean Pack & $34^{\circ} 14.34^{\prime} \mathrm{N}$ & $29^{\circ} 42.71^{\prime} \mathrm{W}$ & $\mathrm{NA}$ & NA & \\
\hline
\end{tabular}




\section{Data and sample storage and availability}

Physical samples that were taken during POS536 are stored at GEOMAR repositories and can be accessed on request. Local storage of sediment cores is provided by the GEOMAR lithothek, core and rock repository https://www.geomar.de/en/centre/central-facilities/tlz/core-rock-repository

Video and image raw data will be archived in the IT storage infrastructure at GEOMAR and is available on request. All collected data will be made available via the PANGAEA data repository within three years after the cruise.

All navigation, weather, echosounder, and surface water data recorded during POS536 are available for download at http://dship.geomar.de. Dship data files can only be accessed with a valid password.

\section{Acknowledgements}

We are thankful for the great and thorough support by the master of RV Poseidon Matthias Günther and by the entire crew of the ship. This made the cruise a fantastic work experience and a scientific success.

\section{References}

Andrady, A. L. (2011) Microplastics in the marine environment. Marine Pollution Bulletin 62, 1596-1605.

Cózar, A., Echevarría, F., González-Gordillo, J.I., Irigoien, X., Úbeda, B., Hernández-León, S., Palma, Á.T., Navarro, S., García-de-Lomas, J., Ruiz, A., Fernández-de-Puelles, M.L., Duarte, C.M. (2014) Plastic debris in the open ocean. Proceedings of the National Academy of the Sciences of the USA 111, 10239-10244.

Engel, A., Wagner, H., Le Moigne, F. A. C., Wilson, S. T. (2017) Particle export fluxes to the oxygen minimum zone of the Eastern Tropical North Atlantic. Biogeosciences 14, 1825-1838.

Owens, S. A., Buesseler, K. O., \& Sims, K. W. W. (2011). Re-evaluating the 238U-salinity relationship in seawater: Implications for the 238U-234Th disequilibrium method. Marine Chemistry, 127(1-4), 31-39.

Pike, S., Buesseler, K., Andrews, J., Savoye, N., 2005. Quantification of 234Th recovery in small volume sea water samples by inductively coupled plasma-mass spectrometry. Journal of Radioanalytical and Nuclear Chemistry 263, 355-360.

Van Der Loeff, M. R., Sarin, M. M., Baskaran, M., Benitez-Nelson, C., Buesseler, K. O., Charette, M., ... \& Orlandini, K. (2006). A review of present techniques and methodological advances in analyzing 234Th in aquatic systems. Marine Chemistry, 100(3-4), 190-212. 


\section{GEOMAR}

Helmholtz-Zentrum für Ozeanforschung Kiel

\section{GEOMAR Reports}

No.

\section{Title}

FS POSEIDON Fahrtbericht / Cruise Report POS421, 08. - 18.11.2011, Kiel - Las Palmas, Ed.: T.J. Müller, 26 pp, DOI: 10.3289/GEOMAR_REP_NS_1_2012

Nitrous Oxide Time Series Measurements off Peru - A Collaboration between SFB 754 and IMARPE -, Annual Report 2011, Eds.: Baustian, T., M. Graco, H.W. Bange, G. Flores, J. Ledesma, M. Sarmiento, V. Leon, C. Robles, O. Moron, 20 pp, DOI: 10.3289/GEOMAR_REP_NS_2_2012

FS POSEIDON Fahrtbericht / Cruise Report POS427 - Fluid emissions from mud volcanoes, cold seeps and fluid circulation at the Don-_Kuban deep sea fan (Kerch peninsula, Crimea, Black Sea) 23.02. - 19.03.2012, Burgas, Bulgaria - Heraklion, Greece, Ed.: J. Bialas, 32 pp, DOI: 10.3289/GEOMAR_REP_NS_3_2012

RV CELTIC EXPLORER EUROFLEETS Cruise Report, CE12010 - ECO2@NorthSea, 20.07. 06.08.2012, Bremerhaven - Hamburg, Eds.: P. Linke et al., 65 pp, DOI: 10.3289 /GEOMAR REP NS 42012

RV PELAGIA Fahrtbericht / Cruise Report 64PE350/64PE351 - JEDDAH-TRANSECT -, 08.03. - 05.04.2012, Jeddah - Jeddah, 06.04 - 22.04.2012, Jeddah - Duba, Eds.: M. Schmidt, R. Al-Farawati, A. Al-Aidaroos, B. Kürten and the shipboard scientific party, 154 pp, DOI: 10.3289/GEOMAR_REP_NS_5_2013

RV SONNE Fahrtbericht / Cruise Report SO225 - MANIHIKI II Leg 2 The Manihiki Plateau - Origin, Structure and Effects of Oceanic Plateaus and Pleistocene Dynamic of the West Pacific Warm Water Pool, 19.11.2012 - 06.01.2013 Suva / Fiji - Auckland / New Zealand, Eds.: R. Werner, D. Nürnberg, and F. Hauff and the shipboard scientific party, 176 pp, DOI: 10.3289/GEOMAR_REP_NS_6_2013

RV SONNE Fahrtbericht / Cruise Report SO226 - CHRIMP CHatham RIse Methane Pockmarks, 07.01. - 06.02.2013 / Auckland - Lyttleton \& 07.02. - 01.03.2013 / Lyttleton - Wellington, Eds.: Jörg Bialas / Ingo Klaucke / Jasmin Mögeltönder, 126 pp, DOI: 10.3289/GEOMAR_REP_NS_7_2013

The SUGAR Toolbox - A library of numerical algorithms and data for modelling of gas hydrate systems and marine environments, Eds.: Elke Kossel, Nikolaus Bigalke, Elena Piñero, Matthias Haeckel, 168 pp, DOI: 10.3289/GEOMAR_REP_NS_8_2013

RV ALKOR Fahrtbericht / Cruise Report AL412, 22.03.-08.04.2013, Kiel - Kiel. Eds: Peter Linke and the shipboard scientific party, 38 pp, DOI: 10.3289/GEOMAR_REP_NS_9_2013

Literaturrecherche, Aus- und Bewertung der Datenbasis zur Meerforelle (Salmo trutta trutta L.) Grundlage für ein Projekt zur Optimierung des Meerforellenmanagements in Schleswig-Holstein. Eds.: Christoph Petereit, Thorsten Reusch, Jan Dierking, Albrecht Hahn, 158 pp, DOI: 10.3289/GEOMAR_REP_NS_10_2013

1 RV SONNE Fahrtbericht / Cruise Report SO227 TAIFLUX, 02.04. - 02.05.2013, Kaohsiung Kaohsiung (Taiwan), Christian Berndt, 105 pp, DOI: 10.3289/GEOMAR_REP_NS_11_2013

2 RV SONNE Fahrtbericht / Cruise Report SO218 SHIVA (Stratospheric Ozone: Halogens in a Varying Atmosphere), 15.-29.11.2011, Singapore - Manila, Philippines, Part 1: SO218- SHIVA Summary Report (in German), Part 2: SO218- SHIVA English reports of participating groups, Eds.: Birgit Quack \& Kirstin Krüger, 119 pp, DOI: 10.3289/GEOMAR_REP_NS_12_2013

KIEL276 Time Series Data from Moored Current Meters. Madeira Abyssal Plain, $33^{\circ} \mathrm{N}, 22^{\circ} \mathrm{W}$, 5285 m water depth, March 1980 - April 2011. Background Information and Data Compilation. Eds.: Thomas J. Müller and Joanna J. Waniek, 239 pp, DOI: 10.3289/GEOMAR_REP_NS_13_2013 


\section{GEOMAR}

Helmholtz-Zentrum für Ozeanforschung Kiel

\section{GEOMAR Reports}

No.

14 RV POSEIDON Fahrtbericht / Cruise Report POS457: ICELAND HAZARDS Volcanic Risks from Iceland and Climate Change:The Late Quaternary to Anthropogene Development Reykjavík / Iceland - Galway / Ireland, 7.-22. August 2013. Eds.: Reinhard Werner, Dirk Nürnberg and the shipboard scientific party, 88 pp, DOI: 10.3289/GEOMAR_REP_NS_14_2014

RV MARIA S. MERIAN Fahrtbericht / Cruise Report MSM-34 / 1 \& 2, SUGAR Site, Varna - Varna, 06.12 .13 - 16.01.14. Eds: Jörg Bialas, Ingo Klaucke, Matthias Haeckel, $111 \mathrm{pp}$, DOI: 10.3289/GEOMAR_REP_NS_15_2014

RV SONNE, Fahrtbericht / Cruise Report, SO 234/1, "SPACES": Science or the Assessment of Complex Earth System Processes, 22.06. - 06.07.2014, Walvis Bay / Namibia - Durban / South Africa, Eds.: Reinhard Werner and Hans-Joachim Wagner and the shipbord scientific party, 44 pp, DOI: 10.3289/GEOMAR_REP_NS_17_2014

RV POSEIDON Fahrtbericht / Cruise Report POS 453 \& 458, "COMM3D", Crustal Structure and Ocean Mixing observed with 3D Seismic Measurements, 20.05. - 12.06.2013 (POS453), Galway, Ireland - Vigo, Portugal, 24.09. - 17.10.2013 (POS458), Vigo, Portugal - Vigo, Portugal, Eds.: Cord Papenberg and Dirk Klaeschen, 66 pp, DOI: 10.3289/GEOMAR_REP_NS_18_2014

19 RV POSEIDON, Fahrtbericht / Cruise Report, POS469, "PANAREA", 02. - 22.05.2014, (Bari, Italy - Malaga, Spain) \& Panarea shallow-water diving campaign, 10. - 19.05.2014, Ed.: Peter Linke, 55 pp, DOI: 10.3289/GEOMAR_REP_NS_19_2014

20 RV SONNE Fahrtbericht / Cruise Report SO234-2, 08.-20.07.2014, Durban, -South Africa Port Louis, Mauritius, Eds.: Kirstin Krüger, Birgit Quack and Christa Marandino, 95 pp, DOI: 10.3289/GEOMAR_REP_NS_20_2014

21 RV SONNE Fahrtbericht / Cruise Report SO235, 23.07.-07.08.2014, Port Louis, Mauritius to Malé, Maldives, Eds.: Kirstin Krüger, Birgit Quack and Christa Marandino, 76 pp,

DOI: 10.3289/GEOMAR_REP_NS_21_2014

22 RV SONNE Fahrtbericht / Cruise Report SO233 WALVIS II, 14.05-21.06.2014, Cape Town, South Africa - Walvis Bay, Namibia, Eds.: Kaj Hoernle, Reinhard Werner, and Carsten Lüter, 153 pp, DOI: 10.3289/GEOMAR_REP_NS_22_2014

23 RV SONNE Fahrtbericht / Cruise Report SO237 Vema-TRANSIT Bathymetry of the Vema-Fracture Zone and Puerto Rico TRench and Abyssal AtlaNtic BiodiverSITy Study, Las Palmas (Spain) Santo Domingo (Dom. Rep.) 14.12.14 - 26.01.15, Ed.: Colin W. Devey, 130 pp, DOI: $10.3289 /$ GEOMAR_REP_NS_23_2015

24 RV POSEIDON Fahrtbericht / Cruise Report POS430, POS440, POS460 \& POS467 Seismic Hazards to the Southwest of Portugal; POS430 - La-Seyne-sur-Mer - Portimao (7.4. - 14.4.2012), POS440 - Lisbon - Faro (12.10. - 19.10.2012), POS460 - Funchal - Portimao (5.10. - 14.10.2013), POS467 - Funchal - Portimao (21.3. - 27.3.2014), Ed.: Ingo Grevemeyer, 43 pp, DOI: 10.3289/GEOMAR_REP_NS_24_2015

25 RV SONNE Fahrtbericht / Cruise Report SO239, EcoResponse Assessing the Ecology, Connectivity and Resilience of Polymetallic Nodule Field Systems, Balboa (Panama) - Manzanillo (Mexico), 11.03. -30.04.2015, Eds.: Pedro Martínez Arbizu and Matthias Haeckel, 204 pp, DOI: 10.3289/GEOMAR_REP_NS_25_2015 


\section{GEOMAR}

Helmholtz-Zentrum für Ozeanforschung Kiel

\section{GEOMAR Reports}

No. Ongoing Magmatic-Hydrothermal Discharge of the El Hierro Submarine Volcano, Canary Islands by the Submersible JAGO, Valverde - Las Palmas (Spain), 07.02.-15.02.2016, Eds.: Hannington, M.D. and Shipboard Scientific Party, DOI: 10.3289/GEOMAR_REP_NS_31_2016

32 RV METEOR Fahrtbericht/ Cruise Report M127, Extended Version, Metal fluxes and Resource Potential at the Slow-spreading TAG Midocean Ridge Segment (26N, MAR) - Blue Mining@Sea, Bridgetown (Barbados) - Ponta Delgada (Portugal) 25.05.-28.06.2016,

Eds.: Petersen, S. and Shipboard Scientific Party, DOI: 10.3289/GEOMAR_REP_NS_32_2016

33 RV SONNE Fahrtbericht/Cruise Report SO244/1, GeoSEA: Geodetic Earthquake Observatory on the Seafloor, Antofagasta (Chile) - Antofagasta (Chile), 31.10.-24.11.2015,

Eds.: Jan Behrmann, Ingo Klaucke, Michal Stipp, Jacob Geersen and Scientific Crew SO244/1, DOI: 10.3289/GEOMAR_REP_NS_33_2016

34 RV SONNE Fahrtbericht/Cruise Report SO244/2, GeoSEA: Geodetic Earthquake Observatory on the Seafloor, Antofagasta (Chile) - Antofagasta (Chile), 27.11.-13.12.2015,

Eds.: Heidrun Kopp, Dietrich Lange, Katrin Hannemann, Anne Krabbenhoeft, Florian Petersen, Anina Timmermann and Scientific Crew SO244/2, DOI: 10.3289/GEOMAR_REP_NS_34_2016

35 RV SONNE Fahrtbericht/Cruise Report SO255, VITIAZ - The Life Cycle of the Vitiaz-Kermadec Arc / Backarc System: from Arc Initiation to Splitting and Backarc Basin Formation, Auckland (New Zealand) - Auckland (New Zealand), 02.03.-14.04.2017, Eds.: Kaj Hoernle, Folkmar Hauff, and Reinhard Werner with contributions from cruise participants,

DOI: 10.3289/GEOMAR_REP_NS_35_2017 


\section{GEOMAR}

Helmholtz-Zentrum für Ozeanforschung Kiel

\section{GEOMAR Reports}

No.

RIA S. MERIAN Fahrtbericht/Cruise Report MSM71, LOBSTER: Ligurian Ocean Bottom Seismology and Tectonics Research, Las Palmas (Spain) - Heraklion (Greece), 07.02.-27.02.2018, Eds.: H. Kopp, D. Lange, M. Thorwart, A. Paul, A. Dannowski, F. Petersen, C. Aubert, F. Beek, A. Beniest, S. Besançon, A. Brotzer, G. Caielli, W. Crawford, M. Deen, C. Lehmann, K. Marquardt, M. Neckel, L. Papanagnou, B. Schramm, P. Schröder, K.-P. Steffen, F. Wolf, Y. Xia, DOI: 10.3289/GEOMAR_REP_NS_41_2018

RV METEOR Fahrtbericht/Cruise Report M143, SLOGARO: Slope failures and active gas expulsion along the Romanian margin - investigating relations to gas hydrate distribution, Varna (Romania) Heraklion (Greece), 12.12.-22.12.2017, Eds.: M. Riedel, F. Gausepohl, I. Gazis, L. Hähnel, M. Kampmeier, P. Urban, J. Bialas, DOI: 10.3289/GEOMAR_REP_NS_42_2018

RV POSEIDON Fahrtbericht/Cruise Report POS510, ANYDROS: Rifting and Hydrothermal Activity in the Cyclades Back-arc Basin, Catania (Italy) - Heraklion (Greece), 06.03.-29.03.2017, Ed.: M.D. Hannington, DOI: 10.3289/GEOMAR_REP_NS_43_2018

44 RV POSEIDON Fahrtbericht/Cruise Report POS524, GrimseyEM: Geophysical and geological investigations in the vicinity of the Grimsey Hydrothermal Field offshore Northern Iceland for the assessment of the geothermal potential and the exploration for potential mineralizations within the seafloor, Reykjavik (Iceland) - Bergen (Norway), 7.6 - 26.6.2018, Eds.: Sebastian Hölz and Sofia Martins, DOI: 10.3289/GEOMAR_REP_NS_44_2018

45 RV POSEIDON Fahrtbericht/Cruise Report POS527, Baseline Study for the Environmental Monitoring of Subseafloor $\mathrm{CO}_{2}$ Storage Operations, Kiel - Kiel (Germany), 15.8. - 3.9.2018, Eds.: Eric Achterberg and Mario Esposito, DOI: 10.3289/GEOMAR_REP_NS_45_2018 


\section{GEOMAR}

Helmholtz-Zentrum für Ozeanforschung Kiel

\section{GEOMAR Reports}

No.

Title

46 RV SONNE Fahrtbericht/Cruise Report SO264, SONNE-EMPEROR: The Plio/Pleistocene to Holocene development of the pelagic North Pacific from surface to depth - assessing its role for the global carbon budget and Earth's climate, Suva (Fiji) - Yokohama (Japan), 30.6. - 24.8.2018 Ed.: Dirk Nürnberg, DOI: 10.3289/GEOMAR_REP_NS_46_2018

47 RV SONNE Fahrtbericht/Cruise Report SO265, SHATSKY EVOLUTION: Evolution of the Shatsky Rise Hotspot System, Yokohama (Japan) - Kaohsiung (Taiwan), 26.08. - 11.10.2018, Eds.: Jörg Geldmacher, Reinhard Werner, and Folkmar Hauff with contributions from cruise participants, DOI: $10.3289 / G E O M A R \_R E P \_N S \_47 \_2018$

48 RV MARIA S. MERIAN Fahrtbericht/Cruise Report MSM78, PERMO 2, Edinburgh - Edinburgh (U.K.), 16.10. - 25.10.2018, Eds.: Jens Karstens, Christoph Böttner, Mike Edwards, Ismael Falcon-Suarez, Anita Flohr, Rachael James, Anna Lichtschlag, Doris Maicher, Iain Pheasant, Ben Roche, Bettina Schramm, Michael Wilson, DOI: 10.3289/GEOMAR_REP_NS_48_2019

49 RV SONNE Fahrtbericht/Cruise Report SO267, ARCHIMEDES I: Arc Rifting, Metallogeny and Microplate Evolution - an Integrated Geodynamic, Magmatic and Hydrothermal Study of the Fonualei Rift System, NE Lau Basin, Suva (Fiji) - Suva (Fiji), 11.12.2018 - 26.01.2019, Eds.: Mark Hannington, Heidrun Kopp, Michael Schnabel, DOI: 10.3289/GEOMAR_REP_NS_49_2019

50 RV Pelagia Fahrtbericht/Cruise Report 64PE-445, SALTAX: Geomorphology and geophysics of submarine salt flows in the Red Sea Rift, Limassol (Cyprus) - Safaga (Egypt), 27.08. - 21.09.2018, Eds.: Nico Augustin, Neil C. Mitchell, Froukje M. van der Zwan \& Scientific Shipboard Party,

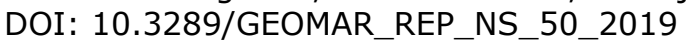

51 RV POSEIDON Fahrtbericht/Cruise Report POS526, SeASOM: Semi-Autonomous Subsurface Optical Monitoring for methane seepage and cold-water coral studies in the North Sea, Bergen (Norway) - Doggerbank (Netherlands) - Hirtshals (Denmark) - Tisler (Norway) Kiel (Germany), 23.07. - 11.08.2018, Eds.: Jens Greinert, Tim Schoening, DOI: $10.3289 / G E O M A R \_R E P \_N S \_51 \_2019$

52 RV POSEIDON Fahrtbericht/Cruise Report POS534, STEMM-CCS: Strategies for Environmental Monitoring of Marine Carbon Capture and Storage, Leg 1: Kiel (Germany) - Aberdeen (United Kingdom), 01.05. - 22.05.2019, Leg 2: Aberdeen (United Kingdom) - Bremerhaven (Germany), 23.05. - 29.05.2019, Ed.: Mark Schmidt, DOI: 10.3289/GEOMAR_REP_NS_52_2019

53 RV POSEIDON Fahrtbericht/Cruise Report POS535, Loki2GrimseyEM: Geophysical and geological investigations of massive sulfides at and in the vicinity of Loki's Castle (Norway) and similar experiments around the Grimsey Hydrothermal Field (Iceland) for the assessment of the geothermal potential and the exploration for potential mineralizations within the seafloor, Akureyri (Iceland) - Bremerhaven (Germany), 09.06 - 03.07.2019, Eds.: Sebastian Hölz, Amir Haroon and Sofia Martins, DOI: 10.3289/GEOMAR_REP_NS_53_2019

54 Practical Guide for Environmental Monitoring of Conventional Munitions in the Seas, Results from the BMBF funded project UDEMM "Umweltmonitoring für die Delaboration von Munition im Meer" Ed.: Jens Greinert, DOI: 10.3289/GEOMAR_REP_NS_54_2019

55 RV ALKOR Fahrtbericht/Cruise Report AL533, Mutual Field Trials of the Manned Submersible JAGO and the Hover-AUVs ANTON and LUISE off the Aeolian Islands, Mediterranean Sea, Catania (Italy)La Seyne-sur-mer (France), 05.02. - 18.02.2020, Authors: Karen Hissmann, Marcel Rothenbeck, Emanuell Wenzlaff, Tim Weiß, Patrick Leibold, DOI: 10.3289/GEOMAR_REP_NS_55_2020 


\section{GEOMAR}

Helmholtz-Zentrum für Ozeanforschung Kiel

\section{GEOMAR Reports}

No.

Title

56 RV POSEIDON Fahrtbericht/Cruise Report POS536/Leg 1, DIPLANOAGAP: Distribution of Plastics in the North Atlantic Garbage Patch, Ponta Delgada (Portugal) - Malaga (Spain),

17.08. - 12.09.2019, Author: Mark Lenz, DOI: 10.3289/GEOMAR_REP_NS_56_2018

For GEOMAR Reports, please visit:

https://oceanrep.geomar.de/view/series/GEOMAR_Report.html

Reports of the former IFM-GEOMAR series can be found under:

https://oceanrep.geomar.de/view/series/IFM-GEOMAR_Report.html 


\section{GEOMAR}

Helmholtz-Zentrum für Ozeanforschung Kiel

Das GEOMAR Helmholtz-Zentrum für Ozeanforschung Kiel ist Mitglied der Helmholtz-Gemeinschaft

Deutscher Forschungszentren e.V.
The GEOMAR Helmholtz Centre for Ocean Research Kiel is a member of the Helmholtz Association of German Research Centres

Helmholtz-Zentrum für Ozeanforschung Kiel / Helmholtz Centre for Ocean Research Kiel GEOMAR

Dienstgebäude Westufer / West Shore Building

Düsternbrooker Weg 20

D-24105 Kiel

Germany

Helmholtz-Zentrum für Ozeanforschung Kiel / Helmholtz Centre for Ocean Research Kiel GEOMAR

Dienstgebäude Ostufer / East Shore Building

Wischhofstr. 1-3

D-24148 Kiel

Germany

Tel.: +49 $431600-0$

Fax: +49 431 600-2805

www.geomar.de 